\title{
La organización militar de la Orden de Calatrava en el Alto Guadalquivir a través de las investigaciones arqueológicas
}

Juan Carlos Castillo Armenteros

José Luis Castillo Armenteros

Universidad de Jaén

Grupo de Investigación del Patrimonio

Arqueológico de Jaén

\section{INTRODUCCIÓN}

En este estudio pretendemos analizar la consolidación del señorío de la Orden de Calatrava en el Alto Guadalquivir durante la Edad Media. Y en este marco, estudiar la evolución de la estructura ofensiva-defensiva que establece para organizarlo, protegerlo y repoblarlo. Para ello nos apoyaremos en diversas investigaciones arqueológicas, las cuales han permitido conocer ampliamente las transformaciones introducidas por la Orden en las fortificaciones islámicas y en el sistema de organización y control espacial creado previamente por los musulmanes, y todo ello, como consecuencia de la formación de una activa frontera entre la primera mitad del siglo XIII y finales del $\mathrm{XV}$.

Para alcanzar tal objetivo se han llevado a cabo diversos estudios arqueológicos en los territorios de la Orden, los cuales podrían agruparse en dos grandes grupos:

- Por un lado una exhaustiva prospección superficial, que nos ha permitido documentar numerosas fortificaciones y estructuras defensivas, tanto rurales como urbanas.

- Y por otro, la excavación de varias de las fortalezas de la Orden, entre las que des- tacaremos los castillos de Alcaudete, Sabiote y Torredonjimeno.

Asimismo, el marco cronológico en el que se circunscribe este estudio cabría dividirlo en dos grandes etapas, una primera de consolidación, que abarcaría la primera mitad del siglo XIII, tras la donación a la Orden de Martos ( 1228 ), y el progresivo incremento de sus dominios con la incorporación de núcleos como Alcaudete (1246), Sabiote (1257), etc. Y una segunda, que identificamos con la segunda mitad del siglo XIV y primera mitad del siglo XV, durante la cual perderá definitivamente algunas posesiones, en el sector Suroeste, mientras que adquiere otras en Sierra Mágina, en un ámbito territorial cercano a la frontera con el reino nazarí de Granada.

\section{LA FORMACIÓN DEL SEÑORÍO EN EL ALTO GUADALQUIVIR}

Numerosos autores han resaltado el importante papel que jugaron las Órdenes Militares en el proceso de conquista de las tierras musulmanas. La ayuda prestada a los reyes cristianos se puede resumir en dos aspectos:

- Por un lado proporcionan efectivos militares en las campañas bélicas. 
- Por otro, guardar y proteger la frontera con el objetivo de asegurar las posiciones cristianas más avanzadas, lo que permitirá repoblar estos territorios conquistados.

Por ambas aportaciones fueron recompensados con amplios privilegios, exenciones, derechos y donaciones de tierras, fortificaciones, etc..

El control de los pasos de Sierra Morena, se convertía en un factor determinante para los monarcas cristianos, a la hora de iniciar las conquista del Valle del Guadalquivir. Por ello tras la batalla de las Navas de Tolosa (12 12), y una vez obtenido el respectivo control de las vías serranas y de algunas fortalezas ', Castilla disponía de un pequeño territorio, desde el cual hostigar a los musulmanes, a la vez que servía de punto de partida para futuras expediciones (CASTILLO, 1998; 2000, MONTES, 1993). A este factor estratégico importantísimo, habría que añadir otros de tipo político que facilitaron los éxitos militares cristianos, por un lado la descomposición del Estado Almohade, y por otro la integración en 1230 de las coronas de Castilla y León en un solo reino.

El origen del patrimonio de la Orden de Calatrava en el Alto Guadalquivir surge en estos momentos, al convertirse esta institución feudal en una de las vanguardias de las tropas cristianas durante las campañas desarrolladas por Fernando III (MENÉNDEZ, 1955; VANDERFORD,
1984; GONZÁLEZ, 2000). Gracias a su activa colaboración el monarca castellano les hizo entrega de numerosas donaciones, por lo general diversos núcleos de población con sus respectivos territorios dependientes.

En I 228 Fernando III entrega a la Orden la fortaleza de Martos con todos sus términos, así como Porcuna, Viboras y veinte yugadas de tierra en Arjona, cuando las mismas fueran conquistadas (A.H.N., 1228; ORTEGA ET ALII, I76I; GONZÁLEZ, 1980). Donación que fue confirmada por Alfonso $X$ en 1254 ?

Las posesiones de la Orden se incrementan paulatinamente a medida que avanza la conquista, así en 1240 se le otorgará los castillos de Locubín y Susana, en 1245 Alcaudete y Priego de Córdoba. Alfonso $X$ complementó estas donaciones con la cesión en 1257 de la villa de Sabiote y en 1272 Alcalá la Real ${ }^{3}$. Este patrimonio se completó en 1300 con la entrega de la villa de Santisteban del Puerto ${ }^{4}$ por el rey Fernando IV (Fig. I).

Este mapa territorial fue incrementándose y transformándose a lo largo del siglo XIV, debido fundamentalmente a los frecuentes avances y retrocesos de la frontera, con la continua perdida y recuperación de algunos núcleos situados en ella, como lo demuestran la perdida de Alcalá la Real y Alcaudete (I300) ${ }^{5}$, esta última nuevamente entregada a la Orden en $|35|^{6}$. O bien, aquellas alteraciones pro-

\footnotetext{
I Proceso de conquista que ha sido ampliamente analizado por GONZÁLEZ, J. "Las conquistas de Fernando III en Andalucía". Hispania, No XXV, Madrid (1946), pp. 5 I5 - 605; BALLESTEROS, M. "La conquista de Jaén por Fernando III el Santo". Cuadernos de Historia de España. Instituto de Historia de España. Buenos Aires (1953), pp. 63 - I 38.

2 ARCHIVO HISTÓRICO NACIONAL. Órdenes Militares, Calatrava, Documentos Reales, N 62 y No 93; ORTEGA ET ALII Bularium Ordinis Militiae de Calatrava, I76I, Ediciones. El Albir, Barcelona (I98I), pp. 93 -94.

3 RODRÍGUEZ MOLINA J. "Las Órdenes Militares de Calatrava y Santiago en el Alto Guadalquivir". Cuadernos de Estudios Medievales, II - III, Granada (I974 - 1975), pág. 63; MONTES NIETO. F. La Orden de Calatrava en la villa de Porcuna (I 5 I 5- I558). Porcuna (1993), pág. 4I; GONZÁLEZ, J. Repartimiento de Sevilla. I, Madrid (I95|), pág. 39; GONZÁLEZ JIMÉNEZ, M. "Algunas cuestiones en torno a los señoríos andaluces del siglo XIII". En SARASA, E. Y SERRANO, E. (Eds.) Señorío y feudalismo en la Península Ibérica. I, Zaragoza (1993), pág. 545.

4 MERCADO EGEA, J. Santisteban del Puerto: Historia y Diplomática hasta finales del siglo XV. Jaén, pág. I83, Documentos N²9, pp. $327-331$ y $N^{\circ} 30$, pp. $331-332$.

5 MARTÍNEZ ANTUÑA, M. "Conquista de Quesada y Alcaudete por Muhammad II de Granada”. Religión y Cultura, 20, Madrid, (1932), pág. 389.; RODRIGUEZ-PICAVEA MATILLA, E. "Génesis y evolución del señorío calatravo en la villa de Alcaudete". Alcaudete en su historia. Alcaudete (1994), pág. 164.

6 MATELLANES MERCHÁN, JV. “El realengo en Alcaudete (1312 - 1385)”. Alcaudete en su historia. Alcaudete (1994), pp.. I89 - 190;
} RODRÍGUEZ MOLINA, J., Opus Cit.. pág. 63. 
ducidas fundamentalmente por donaciones, adquisiciones e intercambios ${ }^{7}$ (Fig. 2).

Finalmente en I 434 el rey Juan II facilitó un nuevo incremento de sus territorios señoriales en el Alto Guadalquivir, gracias a la permuta de los poblados de Maqueda, San Silvestre y Colmenar, por los núcleos de Arjona, Arjonilla, La Figuera, Recena, 3/4 partes de Jimena. Constituyéndose la Encomienda de Torres, Canena, Jimena y el heredamiento de Recena (RODRÍGUEZ, 1974-75) (Fig. 3).

Junto a estos núcleos de población, la Orden también recibió otros bienes rústicos y urbanos repartidos en diferentes puntos del Alto Guadalquivir, especialmente en los términos de los grandes concejos de Jaén, Baeza, Úbeda y Andújar (RODRÍGUEZ, 1974-75; GONZÁLEZ, 1995; 2000).

De esta manera la Orden de Calatrava adquirió un extenso territorio situado en el extremo Suroeste de la actual provincia de Jaén, controlando amplias zonas de la Campiña y buena parte del piedemonte de las Sierras Sur. Desde sus dominios ejerció un exhaustivo control de las principales vías de comunicación que unín Jaén con Córdoba y Granada (Fig. 4), así como de todos aquellos puentes que permitían vadear los cursos de agua más importantes que discurrían por este territorio (Láms. I, $2,3,4)$. Así pues, durante cada una de las fases en las que podemos dividir la consolidación de su señorío en el Alto Guadalquivir, la Orden emprende una significativa labor de fortificación, con el objetivo de controlar militar y administrativamente este amplio territorio fronteri- zo ${ }^{8}$. Prueba de ello, son las numerosas atalayas, torres y castillos rurales edificados durante una primera fase, en las demarcaciones de las Encomiendas de Porcuna, Martos y Torredonjimeno. Esquema que se completa con las erigidas entre Alcaudete y Castillo de Locubín en un segundo momento. Esta sólida barrera defensiva-ofensiva ${ }^{9}$ cerraba por completo el acceso al epicentro de sus posesiones en el antiguo Reino de Jaén, emplazado en la inexpugnable villa de Martos (Fig. 12).

Este panorama fue el resultado de la política desarrollada por los reyes castellanos, con el objetivo de proteger, defender y repoblar todas aquellas áreas más estratégicas y fronterizas, dado que carecían de un ejército numeroso y permanente. De esta manera, todos los señoríos creados en el Alto Guadalquivir por la monarquía castellana tuvieron como objetivo, por un lado servir de recompensa por los servicios militares prestados en la conquista de este territorio andalusí, y por otro, convertirse en una sólido escudo protector de la zona central (donde se ubicaban los grandes Concejos de realengo) frente a las posibles incursiones del reino Nazarí de Granada ${ }^{10}$.

\section{LA FORMACIÓN DE UNA FRONTERA}

Una vez formado y organizado el señorío, resultaba vital su repoblación, con lo que se garantizaba por un lado control del territorio, y por otro, su explotación económica, generando las rentas necesarias para el funcionamiento de esta institución feudal. Para poder

\footnotetext{
7 RODRÍGUEZ MOLINA, J., Opus Cit. pág. 66

8 Esta función administrativa, política, organizadora y jerarquizadora del espacio desarrollada por las fortalezas de la Orden de Calatrava ha sido puesta de manifiesto por C. de AYALA “Las fortalezas castellanas de la Orden de Calatrava en el siglo XII". En la España Medieval, N I6, Madrid (1993), pp. 9 - 35.

9El papel ofensivo-defensivo de las fortificaciones medievales ha quedado constatado en los estudios de GARCÍA FITZ, F. Castilla y León frente al Islam. Estrategias de expansión y tácticas militares (siglos XI - XIII). Sevilla (1998); "Pora acreçentamiento de nuestros regnos. Las funciones ofensivas de los castillos de frontera". En BARRIO, JA. Y CABEZUELO, JV. (Eds.) La fortaleza medieval. Realidad y símbolo. Murcia (1998), pp. 75 - 89; "Guerra y fortificaciones en contextos de frontera. Algunos casos ibéricos de la Plena Edad Media". Mil anos de fortificaçoes na Península Ibérica e no Magreb (500 - 1500): Actas do Simposio Internacional sobre Castelos. Lisboa (200I), pp.5I9- 532 .

IORODRÍGUEZ MOLINA, J. El Reino de Jaén en la Baja Edad Media. Aspectos demográficos y económicos. Granada, (I975), pp. 7- 8; MONTES NIETO, F. Opus cit., pp. $39-40$.
} 
llevar a cabo esta labor, era imprescindible ofrecer una mínima organización territorial y una relativa seguridad a la población que allí se trasladase.

Para cubrir este objetivo la Orden de Calatrava, siguiendo una costumbre, ya ejecutada en el Campo de Calatrava (RODRÍGUEZ-PICAVEA, 1994), estructura el territorio en encomiendas (MENDOZA, 1996; AYALA, 1999; 2003). Una encomienda era una circunscripción asignada a un miembro de la institución para que la administrase económica y jurídicamente, a la vez que la defendía. Cada una de ellas solía comprender un territorio relativamente extenso que incluía diversos núcleos de población (villas, aldeas e incluso lugares con un fuerte carácter rural), siendo el de mayor tamaño el que daba nombre a la encomienda, y en el cual residía el comendador.

Sin embargo, tras la conquista del Alto Guadalquivir, no fueron muchas las encomiendas establecidas en la zona. Según la documentación del siglo XIII conservada, las posesiones de la Orden se agrupaban dentro de las encomiendas de Martos, Baeza, Canena, Alcaudete, Sabiote, Porcuna, Viboras y Torredonjimeno " (Fig. I ). Como ya hemos señalado, este panorama inicial se transformaría a lo largo del siglo XIV y XV, ya que la dinámica política y militar en la zona generó una nueva organización espacial (Fig. 2). En este marco, aunque muchas de las antiguas encomiendas aún existían a finales del siglo $X V^{12}$ (Fig. 3), otras por el contrario se perdieron definitivamente (Alcaudete, Arjona), a la vez que se sumaban nuevas incorporaciones, entre ellas las encomiendas de Lopera, Subclavería, la Torre del Cañaveral, y la encomienda de Torres, Canena y Jimena.

Cada una de ellas tendría su propia organización interna, desde el punto de vista ofensivo-defensivo, que es el que nos ocupa, observamos como en ellas existía una clara jerarquización de estructuras militares. No obstante habría que señalar, que esta organización militar del espacio, no responde a un modelo implantado por los calatravos, sino que éstos heredan en gran parte el esquema establecido anteriormente por los musulmanes ${ }^{13}$. De esta manera encabezando la encomienda, aparecería el núcleo de población más importante, Martos (Lám. 2, A), Alcaudete (Lám. 2, C), Sabiote (Lám. 2, D), Canena (Lám. 2, E); Víboras (Lám. 2, B y B'), Porcuna (Fig. 8; Lám. 3, A), Torredonjimeno ${ }^{14}$ (Fig. 6; Lám. 3, B y B'), etc., por lo general antiguos Hișn islámicos, que ocupan impor-

II ARCHIVO HISTÓRICO NACIONAL Órdenes Militares, Calatrava, I299, carpeta. 427, documento 155.

12 SOLANO, E. La Orden de Calatrava en el siglo XV. Sevilla (1978), pp. 278 - 290.

13 A este respecto, otros autores han manifestado argumentos semejantes a la hora de abordar el estudio de la organización castral implantada por las Órdenes Militares en los ámbitos espaciales que controlaban. Entre ellos destacar los trabajos de MOLERO, JM. "Sistemas de defensa y control en el Campo de San Juan: del dominio musulmán al cristiano (siglos X - XIII)". IV Congreso de Arqueología Medieval Española, Tomo II, Alicante (1993), pp. 400 - 402; RODRÍGUEZ-PICAVEA, E. La formación del feudalismo en la meseta meridional castellana. Los señoríos de la Orden de Calatrava en los siglos XII - XIII. Madrid (I994), pp. I7 - I 8; IZQUIERDO; R. "EI poblamiento en La Mancha en el siglo XII". ZOZAYA, J. (Ed.) Alarcos'95. El fiel de la balanza. Junta de Comunidades de Castilla-La Mancha (1995), pág. I04; AYALA, C. de "Las Órdenes Militares y la ocupación del territorio manchego (s. XII - XIII)". IZQUIERDO, R. Y RUIZ, F. Alarcos I 195. Actas del Congreso Internacional conmemorativo del VIII Centenario de la Batalla de Alarcos. Cuenca (1996), pág. 68; VALERA, E. "La estructura castral Santiaguista en la Sierra de Segura durante el siglo XIII: aproximación a su tipología". Historia Medieval. Anales de la Universidad de Alicante, II, Alicante (1996-1997), pág. 59I; IZQUIERDO, R. "El espacio de las Órdenes Militares: planteamientos para un análisis arqueológico". IZQUIERDO, R. Y RUIZ, F. Las Órdenes Militares en la Península Ibérica. Volumen I: Edad Media, Cuenca (2000), p. 38; MATELLANES, JV. "Las fortalezas de Segura de la Sierra: aproximación a un marco de organización del espacio (I 235 - 1350)". Actas del IV Curso de Cultura Medieval. Seminario: La fortificación Medieval en la Península Ibérica. Aguilar de Campoo (200 I), pág. 2 I3; RODRÍGUEZ-PICAVEA, E. "Fortalezas y organización territorial en el Campo de Calatrava (siglos XII - XV)". Actas do Simposio Internacional sobre Castelos. Mil anos de fortificaçoes na Península Ibérica e no Magreb (500-1500). Lisboa (200I), pág. 623.

14 Para profundizar en el conocimiento de la fortaleza de Torredonjimeno pueden consultarse los informes de excavación arqueológica: LIZCANO, R. "Memoria de excavación arqueológica: Castillo de Torredonjimeno (Jaén). Campaña de 1990". Anuario Arqueológico de Andalucía 1991, Tomo III, Cádiz (1993), pp. 292 - 304; LIZCANO, R.; AGUAYO, M.; ARAQUE, D.; HERNÁNDEZ, M.; IZQUIERDO, M. Y RUIZ, J. " $2^{a}$ Campaña de excavaciones arqueológicas en el Castillo de Torredonjimeno (laén)". Anuario Arqueológico de Andalucía 1991, Tomo III, Cádiz (1993), pp. 305 - 310. Las excavaciones efectuadas en el castillo han constatado la existencia de esta primitiva fortificación islámica, que fue enormemente transformada entre los siglos XIII-XV (Fig. 6), siguiendo dos fases 
tantes posiciones estratégicas en las inmediaciones de las principales vías de comunicación. Todos estos emplazamientos poseen un amplio control territorial, lo que les permite comunicar visualmente con la mayor parte de las fortalezas de su entorno y con los centros de las encomiendas vecinas (Fig. 12). Asimismo, están dotados de sólidas estructuras de fortificación, que en algunos casos podrían tener un origen ibero-romano, pero que fueron ampliamente transformadas tras la conquista cristiana. Junto a ellos, ocupando este vértice jerárquico, como cabeceras de encomiendas podemos encontrar otras poblaciones, cuyo peso histórico dentro de la zona fue menor, posiblemente estratégicas alquerías islámicas como Jimena ${ }^{15}$ (Fig. 10; Lám. 14) y Lopera ${ }^{16}$ (Lám. 15). Ambos núcleos pudieron fortificarse a principios del siglo XIII, transformando los calatravos ampliamente sus defensas a lo largo de los siglos XIV y $X V$. De esta manera el castillo se convirtió para la Orden en una de sus principales bases de organización territorial (VILLEGAS, 1991; AYALA, 1993; 1996, RODRÍGUEZ-PICAVEA, 1994; 200 I).

Junto a ellos, en un segundo escalafón, y ocupando también inmejorables posiciones estratégicas nos encontramos con diversos castillos integrados en los territorios de cada una de estas encomiendas, algunos de ellos igualmente con un origen islámico como los de Torrebençala (Fig. 5), Arjonilla (Lám. 16), Cotrufe (Fig. 6), Locubín; o aquellas fortalezas posiblemente creadas de nueva planta por la propia Orden como los castillos de Jamilena, Higuera de Calatrava (Lám. 17), Torrevieja (Fuensanta) ${ }^{17}$ (Lám. 18), Alcázar (Torredonjimeno) (Lám. 10), García (Torredonjimeno), etc. Por lo general, estos castillos están dotados de un recinto amurallado de diversas dimensiones y una gran Torre de Homenaje, que era utilizada básicamente como residencia de la guarnición.

claramente diferenciadas. Según sus excavadores en una primera fase de reestructuración, datable en el siglo- XIII, se constituyó una pequeña fortaleza de planta casi rectangular, construida en mampostería con torreones circulares ubicados en sus ángulos, y dotada de un posible acceso a través de una barbacana situada en la parte meridional del recinto. Entre los siglos XIV y XV se lleva a cabo una segunda fase de reorganización de las defensas de la fortificación, en respuesta a los ataques nazaríes a la zona. Las obras consistieron en dotar a la población de un recinto externo que circundara y protegiera al pequeño núcleo que había surgido junto a la fortaleza, y por otro lado, la edificación en el flanco Este de un antemuro ataludado y un foso, que protegiese una zona con claras deficiencias defensivas. Finalmente, la fortificación cambiará su función militar por otra residencial, ya que en su interior, posiblemente adosada a la Torre de Homenaje, la familia Guzmán construye una casa señorial, organizada entorno a dos patios, y a las que pertenecen varias dependencias techadas con alfarjes polícromos de estilo mudéjar, en los que abundan los motivos decorativos vegetales, epigráficos, geométricos y heráldicos. En el siglo XVIII, según las descripciones efectuadas por el Padre Alejandro del Barco (1987), podemos deducir que aún podía contemplarse algunos elementos defensivos del recinto amurallado de Torredonjimeno, así como parte de la estructura del castillo: "...Y verá que todo él en la dicha longitud es igualmente uniforme y de onze palmos de grueso: que es a loque yo atribuyo el que no tuviera a trechos torreones, no fortines, por que todo el muro era tan fuerte como una torre siendo de igual mezcla y travazon de piedras que las caras ... Sin que tampoco falte la peculiar circunstancia de contener en su centro otra interior fortaleza con todas sus preveciones de muros, antemurales, fosos y puertas forradas con fuertes planchas de hierro, y troneras en lo alto, por donde arrojaban piedras contra los que intentaban violentar las, a mas de las defensas laterales que les hacian las torres de todas las figuras redondas, y quadradas que al través las ponia á cubierto (que todo alcance yo á ver en dicho castillo) aunque hoy apenas le quedan algunas cortas se ales de lo que fue antiguamente...". No obstante este mismo autor, señala que la construcción de dos almazaras de aceite por el Duque de Abrantes, provocaron el progresivo declive de la fortificación: “...por que lo han desfigurado desvaratando sus torres, almenas, y antemurales, para aprovechar las piedras en hacer nuevas fábricas de dos molino de aceyte, y nuevas habitaciones de un palacio...". CASTILLO ARMENTEROS, J.C. "Un baluarte de la Orden de Calatrava". Torredonjimeno. En V.AA. Jaén pueblos y ciudades, Tomo VI, Jaén (1997), pp. 2497-2499.

15 El Castillo de Jimena "presenta planta irregular y un recinto amurallado, que emplea en su construcción un sistema mixto, donde se alterna un basamento de mampostería con lienzos de tapial de tierra, engarzándose los quiebros y las esquinas de la muralla con machones de mampostería. De esta manera los mampuestos irregulares se utilizan exclusivamente en la construcción de la Torre de Homenaje y en la dependencia vestíbulo, a través de la cual se accede a la puerta principal de esta torre. A esta técnica constructiva hace mención la Relación de Felipe II (1578) [“...questa villa tiene un castillo con una sola torre que no es muy fuerte y esta labrado parte de piedra de cantería e parte de tapiería. Y el dicho castillo es peque o..." (VILLEGAS Y GARCíA, I 976, pág. I63)]. Internamente la Torre de Homenaje se organiza en dos plantas cubiertas con bóvedas de crucería, existiendo un sótano que podría identificarse con el aljibe". CASTILLO ARMENTEROS, J.C. "Pequeñas alquerías". Jimena. En WV.AA. Jaén pueblos y ciudades. Tomo IV, Jaén, (1997), pp. 1570 - 1573.

I6CASTILLO ARMENTEROS, J.C. “Indicios de poblaciones”. Lopera. En V.AA. Jaén pueblos y ciudades. Tomo V, Jaén (I997), pp. $177 \mid-1773$.

I7El castillo de Torrevieja, se define como una torre rectangular de mampostería irregular, con esquinas redondeadas, internamente se divide en dos plantas, la primera de ellas de gran altura, actualmente muy modificada debido a su uso como vivienda rural. Se estruc- 
Finalmente, las prospecciones arqueológicas documentan diversas torres, que al igual que los castillos, serían edificadas para el control de caminos, minas, salinas, puentes, etc, o bien para la protección de cortijos y pequeños núcleos campesinos. Son generalmente torres de planta cuadrada, que albergan pequeñas dependencias en su interior, es el caso de la Torre de Fuencubierta (Torredonjimeno) (Lám. 20) y la de Triana o Valcotón (Castillo de Locubín) (Lám. 2l), etc., ambas ubicadas en zonas llanas y tierras fértiles. Por el contrario, junto a ellas se documentan torres de planta circular, emplazadas en la cumbre de elevados cerros, caracterizados por una acusada orografía. Por lo general cabe definirlas como torres de mampostería irregular de base maciza, en cuyo inte- rior se construía una dependencia de reducidas dimensiones. Se trata de atalayas de control espacial, que aparte de vigilar el tránsito que discurría por los caminos de la zona, avisaban de cualquier inminente peligro a las fortificaciones cercanas. Entre ellas destacamos la Torre del Algarrobo (Lám. 22) o bien las numerosas torres construidas en las inmediaciones de Martos, Alcaudete y Castillo de Locubín (CEREZO Y ESLAVA, 1989; ESLAVA, 1999 a y b), como la Torre del Moro (Alcaudete) (Lám. 23). Son numerosos los ejemplos conservados en la zona, pero también es significativa la cantidad de casos desaparecidos de los que tan sólo se conserva el topónimo o escasas referencias documentales de difícil localización. Entre ellas destacamos:

\begin{tabular}{|c|c|c|}
\hline Torre & Término Municipal & Estado de Conservación \\
\hline Cerro de la Atalaya & Fuensanta de Martos & Topónimo \\
\hline Torre del Algarrobo & Fuensanta de Martos & Torre Circular \\
\hline Atalaya de la Carrasca & Martos & Topónimo \\
\hline Atalaya de Martos & Martos & Topónimo \\
\hline Castillejo de Belda & Martos & Topónimo \\
\hline Cortijo de la Torre & Martos & Topónimo \\
\hline Torre de Don García & Martos & Topónimo \\
\hline Torre del Corral & Martos & Topónimo \\
\hline Torreblanca & Santiago de Calatrava & Topónimo \\
\hline La Torre & Santiago de Calatrava & Topónimo \\
\hline El Castillejo & Santiago de Calatrava & Topónimo \\
\hline Torre del Cortijo Blanco & Torredonjimeno & Topónimo \\
\hline Torre del Marroqín & Castillo de Locubín & Torre Circular \\
\hline Torre del la Encina Hermosa & Castillo de Locubín & Torre Circular \\
\hline Torre de la Cogolla & Castillo de Locubín & Torre Circular \\
\hline Torre del Puerto & Castillo de Locubín & Torre Circular \\
\hline Torre de los Ajos & Alcaudete & Torre Circular \\
\hline Torre de los Mesegares & Alcaudete & Torre Circular \\
\hline Torre de la Harina & Alcaudete & Torre Circular \\
\hline Torre del Moro & Alcaudete & Torre Circular \\
\hline
\end{tabular}


Un papel secundario dentro del esquema defensivo establecido, lo protagonizarían algunos molinos fortificados ${ }^{18}$, como el Molino del Castillo (Martos) y del Cubo (Torredonjimeno) (Lám. 24 y 25) ${ }^{19}$. Estas estructuras tendrían una triple funcionalidad, por un lado servirían como refugio para campesinos y molineros, protegerían la producción agrícola, y finalmente contribuirían al control territorial de la zona.

La distribución espacial de estas fortificaciones evidencia la existencia de una frontera entre calatravos y musulmanes, en la que pueden diferenciarse dos momentos cronológicos.

- La primera fase, comprendería desde 1228, fecha de la entrega del lqlīm de Mārtūs a la Orden por Fernando III, y las posteriores anexiones, de los Iqlims de Porcuna y Víboras ${ }^{20}$. Esta frontera, que ya estudiamos hace algunos años (CASTILLO ET ALII, 1989, CASTILLO, 1998) se mantuvo activa hasta la conquista de Arjona (1244). El análisis del territorio muestra como los musulmanes, ante el inminente peligro que suponía el avance cristiano, incrementaron de forma significativa el número de sus fortificaciones. Pero si reducimos la escala del territorio analizado podemos observar, como el área inter- media entre las defensas calatravas y islámicas, configura un hinterland, que aproximadamente coincide con el valle del Arroyo Salado de Porcuna.

- La Segunda Fase (I244 - 1247), coincide cronológicamente, con varios hechos significativos, por un lado con la conquista de Alcaudete, Arjona y Jaén. Lo que dio lugar al incremento sustancial de las posesiones de la Orden, y al traslado de la línea fronteriza hacia el Sur, ubicándose entre Alcaudete, Castillo de Locubín, Alcalá la Real y Sierra Mágina.

No obstante, el control de la Campiña de Jaén por parte de los cristianos, generó nuevas transformaciones en la organización territorial de la Orden de Calatrava. En este sentido, como consecuencia de la implantación de la primera línea fronteriza, algunas de las posesiones que desde el Emirato Omeya habían formado parte de los Iqlïms de Märtüs y Bulküna, tras la cesión de éstos a la Orden, permanecieron bajo la autoridad musulmana integrándose en los distritos de Ŷayyān y Arŷūna, lo que provocó profundos cambios en la organización administrativa y territorial de estas demarcaciones. Sin embargo, una vez contro-

turaba en dos salas abovedadas, separadas por un gran de un gran arco de ladrillo, la más pequeña, cubierta con bóveda de cañón, se convierte en zona de tránsito, ya que en ella se localizaba la escalera de acceso a la segunda planta. Junto a ella, nos encontramos con una gran sala, la más importante, cubierta con una bóveda vaída de ladrillo, iluminada y ventilada con cuatro aspilleras. La segunda planta, muy destruida y sin cubierta, estaba compuesta por una única dependencia. La torre estaba protegida por un pequeño recinto rectangular de mampostería irregular, que a modo de falsabraga o antemuro servía para controlar y defender la puerta principal. Como recinto externo, este castillo reaprovecha antiguas estructuras de fortificación ciclópeas pertenecientes a un recinto ibero-romano, que pudo ser utilizado como basamento de su muralla. CASTILLO ARMENTEROS, JC. "Pequeños asentamientos agrícolas" Fuensanta. En VV.AA. Jaén pueblos y ciudades. Tomo III, Jaén (I997), pág. I073.

I8Este papel defensivo también ha sido resaltado por otros autores FLORES SÁNCHEZ, LF. "Molinos medievales fortificados, los grandes ignorados". En Actas del Congreso Internacional de Fortificaciones en el entorno del Bajo Guadalquivir. Alcalá de Guadaíra (200I), pp. 247-253.

19CANO CARRILLO, J. ; ALCÁZAR HERNÁNDEZ, EM. Y MONTILLA TORRES, I. “El molino fortificado del Cubo: Un molino hidráulico harinero del siglo XV'.' En Campaña juvenil de protección del Patrimonio Tecnológico de Andalucía. Sevilla (1994), pp. 287-309.

20El asentamiento de Víboras no aparece considerado como cabecera de lqlīms en la relación de distritos administrativos andalusíes establecida por J. Aguirre (1982) para la Cora de Jaén. Sin embargo, el propio autor ha incidido en varias ocasiones, en el escaso número de distritos existentes en esta Cora en comparación con los contabilizados para Coras vecinas como la de Granada, por lo que ha sugerido la posibilidad de que existieran un mayor número de estos. No obstante, la donación a la Orden de Calatrava en 1228 del distrito de Martos, y de las villas de Porcuna y Viboras para cuando fuesen conquistadas, recogida en las fuentes cristianas, podría indicarnos que las dádivas realizadas por Fernando III, tenían como objetivo entregar a la Orden una amplia área fronteriza formada en gran parte por los territorios que constituyeron los distritos administrativos de Martos, Porcuna y Víboras. Los cuales tras la donación formaron demarcaciones territoriales individualizadas (encomiendas), y cuyos límites con las tierras del realengo fueron refrendados en diferentes deslindes realizados por Fernando III con el asesoramiento de población musulmana (A.H.N. I25I; GONZÁLEZ, 1980; CASTILLO, LARA Y CASTILLO, 1989; MONTES, 1993). 
lada la Campiña por los ejércitos cristianos, surgen diversos conflictos, generados por la indefinición de los límites territoriales que separaban los territorios de las encomiendas calatravas y los pertenecientes a los Concejos de Jaén y Arjona. En este marco de confusión de términos, los calatravos reclamaban la entrega de las posesiones que formaron parte las antiguas demarcaciones territoriales islámicas, y que debido a las fluctuaciones fronterizas quedaron integradas en los territorios del realengo. Esta situación de indefinición territorial incrementó la confusión y el conflicto, hasta el punto que Fernando III en 125I ordenó, por un lado, el deslinde de los términos entre Martos, Jaén y Locubín, y por otro, los de Arjona, Martos y Porcuna ${ }^{21}$. Para realizar esta labor se solicitó la colaboración y el asesoramiento de pobladores musulmanes. El resultado del deslinde fue volver a plasmar sobre el territorio la estructura administrativa y fiscal existente en la zona entre los siglos IX y X. Sin embargo, tras la conquista definitiva de todo este ámbito espacial (s. XIII), los calatravos llevan a cabo una nueva organización del espacio, que consistió en fragmentar los grandes distritos islámicos en unidades territoriales de menor tamaño (Encomiendas de Lopera, Torre del Cañaveral, Subclavería), con el objetivo de ejercer un mayor control territorial.

Sin embargo, esta frontera no se extinguió tras los grandes avances territoriales obtenidos por los ejércitos castellanos durante los siglos XIII y XIV, ya que en la segunda mitad del siglo $X \mathrm{~V}$, volverían a activarse estas líneas fronterizas, como consecuencia de los enfrentamientos nobiliarios desarrollados durante el reinado de Enrique IV, que enfrentó a los partidarios del rey (Miguel Lucas de Iranzo y Beltrán de la Cueva), apoyados por el Concejo de Jaén y los seguidores de una coalición nobiliaria encabe- zada por D. Pedro Pacheco, Marqués de Villena y D. Pedro Girón, Maestre de Calatrava, participando activamente en el conflicto los miembros de la Orden (CARRIAZO, 1940; CUEVAS, DEL ARCO Y DEL ARCO, 200I; TORAL, 1984; RODRÍGUEZ, 1996).

\section{LAS TRANSFORMACIONES INTRODUCIDAS EN LAS FORTIFICACIONES ISLAMICAS. APORTACIONES DESDE LA INVESTIGACION ARQUEOLOGICA}

A continuación haremos una revisión de los resultados obtenidos en recientes investigaciones arqueológicas efectuadas en las fortificaciones de varios de los principales centros de las encomiendas del Alto Guadalquivir. Los estudios arqueológicos confirman la enorme transformación que sufren las primitivas fortificaciones islámicas tras su incorporación al señorío calatravo.

\section{El sistema defensivo de la villa de Alcaudete}

En Alcaudete se configuro una encomienda singular, debido básicamente a su escasa continuidad cronológica ${ }^{22}$, dentro de un marco geográfico de primera índole, la frontera castellano-nazarí.

La presencia de la Orden de Calatrava en la villa se desarrolla en tres momentos diferentes:

- Primera Etapa: Se produce en la segunda mitad del Siglo XIII, iniciándose tras la conquista del núcleo islámico ${ }^{23}$, y la correspondiente configuración del señorío y la encomienda.

\footnotetext{
21 lbidem.

22RODRÍGUEZ-PICAVEA MATILLA, E. “ Génesis y evolución del señorío....”. Opus Cit., pág. I 57.

23Algunos autores consideran que la toma de Alcaudete por los cristianos se produjo en 1245, o incluso antes en I242 (RUIZ, I980). Sin embargo, como ha señalado Rodríguez-Picavea (1994) será a finales de I245, cuando Fernando III donaba la villa y castillo de Alcaudete a la Orden de Calatrava, para cuando fuesen conquistados.
} 
- Segunda Etapa: Acaecida tras su perdida en $1300^{24}$, y su posterior recuperación en $1312^{25}$. Caracterizada con la desaparición del señorío, percibiendo la Orden tan solo derechos eclesiásticos.

- Tercera Etapa: A mediados del siglo XIV, la villa volvió efímeramente al poder calatravo, y lo hizo en función del conflicto que enfrentó a Pedro I y Enrique II Trastámara. Pedro I con el objetivo de atraerse partidarios a su causa, dona a la Orden en 1350 el castillo y villa de Alcaudete con todos sus términos (RODRÍGUEZ-PICAVEA, 1994; MATELLANES, 1994). Sin embargo, la victoria de Enrique II, supuso el fin definitivo de la presencia Calatrava en Alcaudete.

Tras la consolidación de la dinastía Trastámara, la nobleza comienza a monopolizar ciertos espacios de poder. En este marco privilegiado, D. Alfonso Fernández de Montemayor, Adelantado Mayor de la Frontera (1 380), obtuvo importantes beneficios, entre ellos la donación en mayorazgo del señorío de Alcaudete por parte de Juan I en 1385. A partir de este momento la villa quedó adscrita al señorío de los Montemayor (RIVAS, 1992; 1994).

Las defensas de este núcleo de población se encuentran distribuidas por la cumbre del cerro a cuyos pies se dispone de forma anular el actual el caserío de Alcaudete. Su indiscutible emplazamiento estratégico le ha permitido ejercer un amplio control de las principales vías de comunicación que unían Córdoba, Jaén y Granada.

Los restos arqueológicos más antiguos hallados en el cerro del castillo, pertenecen a época islámica (ss. VIII - X), momento en el que se inicia la construcción de una cerca defensiva, utilizada por los habitantes de la zona para refugiarse en caso de peligro. Se trataba básicamente de efímeras estructuras defensivas, posiblemente de tapial de tierra, que se adaptaban a la acusada orografía del terreno. Sin embargo, entre los ss. XI - XII, se modifican estas defensas articulándose lo que será el germen de la fortaleza actual, es decir, la creación de una gran muralla que circunda el núcleo de población, y la construcción de un alcázar en la cumbre del cerro (Fig. I3; Lám. 26). Según las investigaciones en curso, en el interior de esta última apenas se construyeron edificaciones, tan solo alguna dependencia utilizada como almacén, y en aquellos espacios donde los acusados desniveles así lo aconsejaban, se edificaron varios aljibes, que permitiría a la población resistir largos periodos de asedio.

Durante esta época, Alcaudete se identifica en las fuentes como Hiṣn al-Qabḍāq, un núcleo fortificado perteneciente a la Cora de Ilbirra (Granada), y dependiente del partido de Alcalá la Real (Qal’at Yaḥsüb), del que formaba parte de su estructura defensiva junto con otros castillos y atalayas distribuidas por todo el territorio.

Como hemos indicado durante este período, el núcleo de población se rodea de una cerca o muralla construida con tapial de tierra sobre basamento de mampostería, que se auxiliaba con pequeñas torres de planta cuadrada. En la cumbre del cerro se edifica un alcázar con idéntico material, adaptándose perfectamente a la orografía del terreno, aprovechando incluso algunos escarpes naturales como elementos defensivos (Fig. 13).

La conquista cristiana provocó una nueva reestructuración de las defensas de la villa, así, por ejemplo, la cerca o muralla, que circundaba la zona habitada se reviste de muros de mampostería, lo que supone un reforzamiento de las antiguas estructuras, que a partir de estos momentos incrementan su resistencia

24En el año 1300, Muhammad II toma Alcaudete y ordenó la reparación de sus defensas y su aprovisionamiento con armas y víveres, estableciendo en ella un ribat (MARTíNEZ, 1932). De esta manera se puso fin por primera vez a la encomienda.

25En 1312 Alcaudete es recuperado por el infante Don Pedro y convertido por Alfonso XI en villa de realengo (MATELLANES, 1994). 
ante posibles ataques con piezas de artillería. Junto a ello, se amplían también el número de torres que la defienden. Por el contrario, el antiguo alcázar mantendrá en líneas generales, su antigua fisonomía, aunque siendo utilizado ahora como antemuro y basamento de un nuevo castillo. Ya que, en su interior los calatravos edifican una nueva fortaleza (Láms. 26 y 27), separada de la primitiva por un reducido pasillo (Liza). Para ello derriban parte de las murallas islámicas hasta quedar reducidas a una cerca de dos o tres metros de altitud (Falsabraga), con ello se configuraba una liza entre ambos lienzos, con la que se pretendía incrementar la inexpugnabilidad de la fortaleza, al tiempo que su escasa altura facilitaba a la guarnición el uso de todo tipo de armamento defensivo (Lám. 28, 29 y 30).

El acceso al interior del conjunto fortificado seguía un exhaustivo proceso de control, diseñado sobre el terreno, mediante el cual una vez flanqueadas las puertas de entrada, todos los caminos posibles conducían a la zona de Santa María (Fig. I3), donde se encontraba el sendero que conectaba con el castillo. Una vez en él nos adentrábamos en la liza, recorriendo un amplio tramo de la misma hasta llegar a la puerta principal (Lám. 27). Tan solo la guarnición usaría otras alternativas que comunicaban la fortaleza con el núcleo de población sin tener que penetrar y recorrer la liza.

El nuevo castillo, edificado en mampostería irregular, tiene planta poligonal (Figs. 13 y |4), adaptada perfectamente a la orografía del terreno. A su interior se ingresaba por dos puertas, la puerta principal se situó en el extremo Norte, estando defendida por dos torres de planta cuadrada con sus esquinas externas redondeadas, mientras que la poterna o puerta falsa se localiza en el extremo Sureste.

Una vez franqueada la puerta principal, se accedía directamente a un pasillo-foso fortificado, definido por las murallas del propio castillo y por otros lienzos que intentan aislar y defender una zona central, que se encuentra más elevada que es el resto de la fortaleza, encumbrada en un promontorio rocoso. De esta manera, el área central se configura a modo de una amplia terraza, donde se localizaban los elementos más representativos de la fortificación.

En el interior localizamos varios aljibes, todos ellos emplazados en las zonas de tránsito: El primero, situado en las proximidades de la puerta principal (Fig. I 4), ocupa la planta inferior de un edificio que se adapta perfectamente a la roca, presenta planta cuadrada y a su interior se accedía a través de un vano situado en un lateral. Este aljibe estaba cubierto por una bóveda vaída de ladrillo, que soportaba una estancia rectangular, utilizada como cuerpo de guardia, ya que su puerta se abre directamente al adarve, lo que permitía a los centinelas alcanzar cualquier punto de la fortaleza rápidamente.

El segundo se localiza en el área de las caballerizas, adosado a la entrada de las mismas; presenta planta rectangular cubierta con bóveda de cañón construida de ladrillo. El acceso a su interior se efectuaba a través de un pequeño pozo abierto en la bóveda en uno de sus extremos. El sistema de captación de agua para este aljibe es muy peculiar, ya que era recogida de la cubierta del refectorio y conducida hasta unas pequeñas pero profundas arquetas de decantación, que permitían la introducción de agua limpia a la cisterna.

Sobre el lienzo meridional se apoya un edificio de planta rectangular (Fig. 14) estructurado en dos niveles:

- Al primero, que ocupa el nivel inferior, se accedía después de atravesar el pasillo-foso, está cubierto con una bóveda de cañón y consta de cinco aspilleras alargadas, que permitían la iluminación y la ventilación del interior, así como la defensa del lienzo sobre el que descansa. Ejercía la función de caballerizas.

- Al nivel superior o refectorio se accedía desde la terraza superior o central gracias a un amplio vano, que dejaba paso a un espacio diáfano, cubierto por una estructura de madera. Esta sala esta comunicada directamente con el adarve del lienzo meridional a través de una pequeña puerta. La habitación contaba con un banco corrido, 
posiblemente de ladrillo, apoyado en sus muros, y con un pavimento, también de ladrillo, dispuesto a espiga, sustituido posteriormente por una gruesa capa de mortero de yeso ${ }^{26}$.

En la parte central del castillo se localiza la Torre del Homenaje (Lám. 31 ; Fig. 14), último reducto de resistencia, fue construida en la zona más elevada del promontorio rocoso sobre el que se asienta la fortaleza, quedando aislada del resto, lo que le permite adquirir cierto grado de autonomía funcional o autosuficiencia, marcada por fuertes desniveles rocosos que la circundan. Tiene perfil troncocónico y planta rectangular. Internamente se estructura en tres niveles:

- La planta inferior o almacén: se accedía a través de una trampilla abierta en la bóveda de cañón de piedra que cubre la estancia. La cual presenta un banco corrido adosado a sus muros, que servía para depositar los recipientes de almacenaje. Sin embargo, esta dependencia también sería utilizada como aljibe, ya que en ella, se guardaba el agua de lluvia que se recogía en la parte superior, y canalizada mediante un tubo formado por atanores de cerámica que, embutido en uno de los muros de la torre, conducía el preciado líquido hasta el interior, donde era recogido en grandes tinajas o incluso depositado en su suelo de la estancia, el cual había sido preparado para tal fin, ya que fue construido con una gruesa capa de mortero de cal, que al entrar en contacto con el banco lateral, formaba una pequeña cuenca, evitando así la perdida de agua.

- En la Primera Planta se encuentra la puerta de acceso al interior de la torre. La función de la estancia era permitir la comu- nicación y la conexión con las demás dependencias. El sistema de acceso desde el exterior a la torre está muy destruido, pero consistía en un patín o estructura rectangular adosada a la torre, construida con mampostería, donde se embutía una angosta escalinata, que permitía alcanzar la puerta, situada en alto.

- La Tercera Planta era utilizada como la residencia del comendador, por tanto la zona privilegiada de la fortaleza. Está cubierta con bóveda de cañón de ladrillo, al igual que el nivel anterior. Su ventilación e iluminación se lleva a cabo a través de cuatro ventanas-miradores, construidas con dos arcos de herradura divididos por un parteluz, elementos que evidencian su claro uso residencial.

Tras la toma de Granada y la adscripción de la villa al señorío de Montemayor, la fortaleza pierde su función militar. Los señores de Alcaudete, transformarán el antiguo castillo en residencia particular ${ }^{27}$.

\section{Las fortificaciones de la Encomienda de la Peña de Martos}

Como ya hemos señalado, esta encomienda se constituye tras la entrega que Fernando III realiza a la Orden en 1228 de la fortaleza de Martos con todos sus términos. Martos fue una importante ciudad ibero-romana, la Augusta Gemela Tuccitana (Tucci), con una estructura compleja y jerarquizada, que desde el punto de vista defensivo se organizó en dos áreas (Lám. 5): por un lado la Peña, un elevado macizo rocoso, que sin lugar a dudas puede ser considerado como uno de los principales hitos estratégicos de la Campiña de Jaén; y por otro, el amplio espolón sobre el que se asienta el

26CASTILLO ARMENTEROS, JL. "Gran fortaleza”. Alcaudete. En VV.AA. Jaén pueblos y ciudades. Tomo I, Jaén (1997), pág. 2 I I; CASTILLO ARMENTEROS, JL. "La Orden de Calatrava en el Castillo de Alcaudete". En VV.AA. Visitas al Patrimonio Histórico de Jaén 94199, Colegio Oficial de Arquitectos de Jaén. Jaén (2000), pp. 148 - 153.

27Transformaciones que han sido tratadas ampliamente en nuestro trabajo CASTILLO RMENTEROS, JC. Y CASTILLO ARMENTEROS, JL. "Aportaciones arqueológicas al estudio de las fortificaciones señoriales del Alto Guadalquivir (Jaén) entre los siglos XV y XVI". Mil anos de Fortificaçoes na Península Ibérica e no Magreb (500-1500): Actas do Simposio Internacional sobre Castelos. Lisboa (200I) pág. $719-732$. 
primitivo núcleo urbano, situado en la propia ladera de la Peña, ocupando cotas altimétricas inferiores. No obstante, ambos conjuntos se enlazaron en la Baja Edad Media a través de varios lienzos de muralla.

Aunque los estudios arqueológicos realizados en este municipio no se han extendido al recinto amurallado, contamos con algunos estudios específicos del mismo, que evidencian la existencia de una compleja estructura defensiva $^{28}$, compuesta por una cerca de mampostería irregular intercalada con torres cuadradas y semicirculares. Ocupando la zona más elevada de este espolón rocoso, se localiza la alcazaba, un nuevo recinto amurallado, delimitado por una vaguada, que le eleva también sobre el resto del caserío. Este nuevo espacio amurallado, se define como un conjunto rectangular, que ocupa el antiguo solar de la primitiva acrópolis iberoromana, convertida posteriormente en alcazaba por los musulmanes entre los siglos XI-XIII (Lám. 32). Inicialmente ambos elementos defensivos se edificaron, como la mayor parte de las fortificaciones de la zona, en tapial de argamasa, siendo revestidos en mampostería tras la conquista cristiana, ampliándose sus posibilidades defensivas con torres macizas de planta cuadrada y circular. Ocupando la zona más elevada de la alcazaba, se edificó un alcázar, del que tan solo se conserva una esbelta torre de Homenaje.

Por lo que respecta a la fortaleza emplazada en la cumbre de la Peña (Lám. 33), ocupa una amplia meseta, con una apreciable inclinación Sur - Norte. Tampoco en ella se han efectuado trabajos arqueológicos, tan solo varios estudios superficiales, que han puesto de manifiesto la importancia y la riqueza de este conjunto arqueológico ${ }^{29}$. Esta fortificación ocupa toda la meseta de la cumbre, con lo cual aprovecha las fuertes pendientes y la acusada orografía como elementos defensivos naturales (Hișn). Inicialmente esta cualidad permitía su fácil defensa, pero paulatinamente fue dotándose de un recinto amurallado que circundó toda la meseta, configurando de esta manera una fortaleza de planta irregular.

Tras la conquista, los caballeros calatravos, siguiendo una costumbre muy extendida por todo el Alto Guadalquivir, modifican ampliamente este Hișn, que convierten en una de las principales fortalezas de la Campiña, desde la cual mantendrían contactos visuales con la mayor parte de las posesiones de la Orden. La reestructuración de la fortificación consistió en reutilizar las antiguas defensas sobre las que se edifican un primer recinto amurallado, dotado de torres defensivas de plantas cuadradas y circulares (Fig. 15; Lám. 34)., algunas de ellas construidas en época islámica. Al interior se accedía a través de una torre puerta (ESLAVA, 1990). Paralelamente, en la zona más elevada se construyó un alcázar, de planta irregular, donde destaca una gran torre de Homenaje rectangular (Fig. 15, Lám. 35, 36 y 37), organizada en tres pisos, el inferior posiblemente utilizado como aljibe, se encuentra enterrado, conservando su bóveda de cañón. Este conjunto quedó aislado del resto de la meseta a través de un amplio foso (Fig. 15, Lám. 38).

En el extremo Noroeste del recinto de mayor tamaño, se edificaron don grandes depósitos de agua, uno a modo de balsa, del que parten dos canalizaciones. Mientras que el segundo, fue cubierto con bóvedas de arista de ladrillo (Lám. 39). En el interior de este amplio recinto se conservan restos de varias dependencias que futuros trabajos de excavación podían relacionar con almacenes, cocinas, etc..

\section{El Castillo de Lopera}

El primitivo asentamiento islámico de Lopera fue fortificado entre los siglos $\mathrm{XI}-\mathrm{XIII}{ }^{30}$ con la construcción de un recinto que cerraría el

28SALVATIERRA CUENCA, V. (Ed.) Guía arqueológica de la Campiña de Jaén. Granada (1995), pp. 126 - 132.

29ESLAVA GALÁN, J. "El castillo de La Peña de Martos y la Orden de Calatrava”. Boletín del Instituto de Estudios Giennenses, N I 40, Jaén (1990), pp. 149-160; SALVATIERRA CUENCA, V. (Ed.) Guía arqueológica de... , Opus Cit. pp. I3I - 132.

30Para mayor conocimiento de la evolución de este núcleo de población puede consultarse nuestro trabajo de difusión publicado en 
caserío y un alcázar situado en la zona más elevada de la población. De estos elementos son muy escasos los indicios conservados, ya que la muralla fue destruida en 1930 (VALDECANTOS, 1998), y el alcázar, enormemente transformado por la Orden de Calatrava .

Esta fortaleza presenta un primer recinto externo de planta pentagonal (Fig. 12), construido en mampostería irregular, con cinco torres macizas en sus esquinas, tres de planta semicircular y dos cubos rectangulares, que en algunas ocasiones se complementan en su base con un pequeño talud o alambor. Todas ellas están coronadas con una terraza a la que se accede a través de los adarves 16):

Al interior se accedía por dos puertas (Fig.

- I: La Puerta Principal se situaba en el lienzo Este, se encuentra defendida por dos torres y configurada por un arco de medio punto de dovelas de arenisca, que descansan sobre dos columnas de mármol, que flanquean esta entrada. En el centro del vano encontramos otro arco de medio punto elaborado con ladrillo macizo, en el cual se coloca la puerta de dos hojas de madera, encajadas en sus respectivas ranguas. Previamente como medio de defensa de este acceso, se construye en su vertical y a nivel de adarve, una ladronera soportada por cuatro ménsulas, así como una buhedera u orificio situado en el intradós del pasaje de la puerta (Lám. 15).

-2: Según JL. Pantoja (1993), pudo existir una posible Poterna o puerta falsa en el lienzo Oeste, en su lugar, actualmente se localiza un gran portón de acceso a la plaza de armas. Esta sería de menor tamaño, que la principal, siendo utilizada para uso privado de la guarnición.

El interior se organiza entorno a un amplio patio de armas, en cuyo centro se construyó un Segundo Recinto o Alcázar (Fig. 16, Láms. 40 y
4I), configurado por dos grandes torres unidas por dos lienzos de murallas flanqueantes. El sistema defensivo de estos lienzos consiste en un matacán o largo antepecho voladizo sobre el adarve, soportado por arcos de medio punto y contrafuertes, con suelo aspillerado para controlar el pie de muro (Figs. 16, 17 y 18; Lám. $41)$. Este adarve tiene una coronación de similares características al recinto externo, es decir antepecho almenado y aspillerado.

No obstante, los dos elementos que destacan dentro de este alcázar son dos esbeltas torres, la primera de ellas se ubica en el extremo Oeste, siendo utilizada para defender el acceso al interior del alcázar, ya que la puerta principal del mismo se ubica en uno de sus laterales. Esta torre, conocida popularmente como la Torre de San Miguel, tiene planta rectangular, y fue construida con mampostería irregular, reforzando sus esquinas con sillarejo a soga y tizón. Está coronada con un antepecho almenado y aspillerado, así como por una ladronera ubicada en su cara Oeste, que defendía la puerta de acceso al alcázar. Interiormente se organiza en dos plantas abovedadas.

Frente a ella, y ocupando el extremo Este, se localiza la torre de Homenaje, conocida como Torre de Santa María, que tiene planta rectangular con laterales flanqueantes. Está defendida, como la de San Miguel, por antepechos almenados y aspillerados. Presenta en tres de sus frentes, ladroneras de ménsulas de arenisca, sobre las que descansan antepechos de mampostería mixta. Interiormente se organiza en dos niveles, el primero se identifica con un oratorio construido por el Comendador de Lopera D. Juan Pacheco en I535 (PANTOJA, 1993). Presenta bóveda esquifada con una pequeña zona absidal, sus frentes estaban decorados con yeserías renacentistas en las que se alternan la heráldica y motivos religiosos, vegetales y geométricos, junto a ellas en la propia bóveda aparecían diversas inscripciones pintadas, ya desafortunadamente desaparecidas. Posiblemente

la Colección Jaén pueblos y ciudades, Tomo V, pp. II7।-1 I73; y el articulo "Organización militar del espacio de la Orden de Calatrava: El castillo de Lopera" XI Jornadas sobre Historia de Lopera, Jaén, pp. 9 - 37. 
en el siglo XVI se abre la actual puerta de acceso al interior de esta capilla, creándose un cobertizo o pórtico, con artesonado de madera, soportado por columnas y ménsulas de arenisca decoradas.

También en el patio del Alcázar se llevo a cabo una importante intervención encaminada a transformar la primitiva fortaleza en residencia señorial. De esta manera se redujeron las dimensiones la antigua plaza de armas, edificándose un pequeño patio porticado, que según la documentación del siglo $X V$, servía como eje articulador, entorno al cual se ubicaban diversas dependencia.

En 1459 y 1492 el castillo presentaba un lamentable estado de conservación, como manifiestan varios documentos redactados por los freyres visitadores de la Orden de Calatrava, documentación que ha sido analizada por $\mathrm{M}$. Ruiz Calvente (1990). Entre ellos destaca, por su riqueza en detalles, el elaborado por Frey Bartolomé de Almodovar y Frey Juan Mora el día 23 de Marzo de 1459 (A.H.N., I459; CALVENTE, 1990).

\section{La estructura defensiva de la Villa de Sabiote}

Los análisis arqueológicos efectuados en la misma hasta el momento han sido escasos, tan sólo los trabajos desarrollados en la explanada ubicada frente al Castillo (SALVATIERRA Y CHOCLÁN, 1986; HORNOS ET ALII, 1987), y lOS efectuados en el interior de la fortaleza (CASTILLO ET ALII, 1999). Estos estudios ponen de manifiesto la significativa transformación que sufrió esta fortaleza a lo largo de la Edad Media.

Las fuentes árabes de principios del S. XII denominan a esta población con el nombre de Hișn Sabiyūto (VALLVÉ, 1969). A finales del S. XII o inicios del S. XIII, Yãqūt cita la fortaleza de Sibyawt o Sabiyūt como perteneciente al distrito de Ubbaḍat (Úbeda) (AGUIRRE, 1982).
Los sondeos estratigráficos desarrollados tanto dentro como fuera del castillo han documentado materiales cerámicos de época Emiral, aunque no relacionados con estructuras de hábitat o fortificación, por lo que pudieron pertenecer a un Hișn-refugio (Fig. 19) emplazado en un punto elevado y de fácil defensa, utilizado como refugio de los habitantes de varias alquerías del Valle del Guadalimar. Este núcleo fue enormemente modificado entre los siglos XI - XIII. Las excavaciones arqueológicas han documentado los restos de diversos edificios, correspondiente a la retícula interna de un núcleo dotado de una muralla de tapial (SALVATIERRA Y CHOCLÁN, 1986).

Fernando III tomará la ciudad entre 1227 y 1229, durante las operaciones militares en la Loma de Úbeda (AGUIRRE Y JIMÉNEZ, 1979; RUIZ, 1989), no obstante, fue su sucesor, Alfonso $X$, quien en 1257 la entregó a la Orden Militar de Calatrava en compensación por la villa y castillo de Almoguera (SOLANO, 1978).

La conquista cristiana, provoca un abandono rápido de la ciudad, hecho que se observa en algunas de estas viviendas donde la marcha de la población islámica fue rápida y violenta, documentándose algunos niveles de incendio y abandono de objetos y útiles diversos. Este despoblamiento determino que el asentamiento fuese sometido a una profunda transformación interna, entre las que cabría destacar la superposición sobre el antiguo caserío de una nueva retícula urbana. La repoblación de Sabiote trajo consigo un significativo crecimiento de la población en dirección Oeste, dotándose de un nuevo cinturón de murallas de mampostería, defendida por torres de planta cuadrada. A su interior se accedía por cinco puertas: P. Canal, P. Santos, P. San Sebastián, P. de la Villa y P. del Tejar (Fig.22). Asimismo, se construyeron nuevos espacios de culto, con sus correspondientes necrópolis, como la Iglesia de Santa María del Cortijo, edificada en las inmediaciones del castillo ${ }^{31}$, etc. Pero sobre todo, este abandono

\footnotetext{
3I Iglesia y necrópolis que fueron documentados en diversas campañas de excavación arqueológica, SALVATIERRA, V. Y CHOCLÁN, C. "Excavaciones arqueológicas en Jaén: Sabiote". Actas del V Coloquio Internacional de Historia Medieval de Andalucía. Córdoba (1986) pp. 787-791.
} 
determinó, que la Orden de Calatrava construyera una fortificación situada en el extremo Noreste del Hișn (Figs.20 y 21; Lám. 42), que destruirá gran parte de su estructura interna. La fortaleza fue edificada en mampostería, presenta planta rectangular con torres cuadradas en cada ángulo, y dos más en el lienzo Norte. Para su construcción se aprovechan algunos elementos de fortificación islámicos (lienzos Norte y Este del antiguo Hișn), que son revestidos con amplios forros de mampuestos irregulares.

Al interior (Fig. 2I) de la fortaleza se accedía a través de la puerta principal localizada en el extremo Noroeste, protegida por dos torres. Desde ella y accediendo al interior (dirección Este), se estableció un camino-foso (Lám. 43) protegido por el lienzo Norte del castillo y el muro perimetral del Patio de Armas. El pasillo o foso sigue siempre en dirección este hasta llegar a una torre, desde la cual se permitía el acceso al interior de la plaza de armas. Posiblemente debió existir un acceso directo desde la villa al interior del castillo, que podría localizarse en el lienzo Sur.

El castillo de Sabiote sufrirá restauraciones en 1533 y $\mathbf{1 5 3 5}$, un poco antes de la gran transformación que se realizará en la fortaleza, tras ser comprada por Francisco de los Cobos (RUIZ, 1989). Las obras fueron programadas por el Consejo de la Orden de Calatrava. De esta manera, por Real Provisión de su Majestad se libran por los señores del Consejo de las Ordenes, la concesión de cien mil maravedies al alcaide del castillo y fortaleza de Sabiote, Frey Juan de la Tovilla, para realizar las obras más necesarias. La inspección de los trabajos la efectúa el I 4 de julio de 1535 el Comendador Frey Hernando Chacón, el cual recomendará nuevas obras. La documentación hace mención a una serie de restauraciones puntuales en algunos elementos, al tiempo que nos indica los nombres de las diferentes torres que la componen: Torre del Homenaje o del León (Fig. 2I) que podría corresponderse con la torre de la esquina Suroeste, siguiendo en dirección Este se localizaría la puerta de entrada a la fortaleza protegida por una torre que llevaría su nombre (esquina Sureste), de esta torre y tomando dirección Norte encontraríamos la torre del Espolón (esquina Noreste), de ella parte un lienzo de muralla con sentido Este, que nos conduce a la torre del Baluarte y otro, con dirección Oeste, en el cual se localizan tres torres dos de ellas sin denominar y la tercera que coincide con la esquina Noroeste llamada de la Puerta de la Canal, porque a ella se adosaba una de las entradas a la ciudad. Existiría una última torre que se ubica dentro de la fortaleza y que hemos identificado con la torre que controla el camino-foso.

Sabiote perteneció a la Orden Militar de Calatrava hasta finales del S. XV o principios del XVI, momentos en los que es vendida por Don Alonso de Baeza a Don Francisco de los Cobos, por la cantidad de 18 millones de maravedís. A partir de aquí, el nuevo propietario encarga a Andrés de Vandelvira y al ingeniero Benedetto de Ravena la reforma del castillo para transformarlo en un majestuoso palacio renacentista (CHUECA, 1971; RUIZ, 1989; CASTILLO ET ALII, 1999; COOPER, 199I) (Láms. 42 y 44).

\section{BIBLIOGRAFIA}

AGUIRRE, FJ. (1982) "El Jaén islámico". WV.AA. Historia de Jaén. Jaén, pp. 163 - 200.

AGUIRRE SÁDABA, FJ. y JIMÉNEZ MATA, MC. (1979) Introducción al Jaén Islámico. Jaén.

ARCHIVO HISTÓRICO NACIONAL Consejo Órdenes Militares, Leg. 6105, No 4

ARCHIVO HISTÓRICO NACIONAL, Órdenes Militares, Calatrava, Registro de Escrituras de Calatrava, Tomo III, Sign. 1342 C, fol. 59.

ARCHIVO HISTÓRICO NACIONAL, Órdenes Militares, Calatrava, carpeta 422, R-76.

ARCHIVO HISTÓRICO NACIONAL ( 299 ), Órdenes Militares, Calatrava, carpeta 427, Documento 155.

ARCHIVO HISTÓRICO NACIONAL ( 1228). Órdenes Militares, Calatrava, Documentos Reales, Nº 62 y No 93.

ARCHIVO HISTÓRICO NACIONAL (I25I) Órdenes Militares, Calatrava, R.76.

ARCHIVO HISTÓRICO NACIONAL ( 1459). Órdenes Militares, Calatrava, Consejo. Legajo 6109, Expediente $N^{\circ}$ 39, Folio 236. 
ARCHIVO HISTÓRICO NACIONAL: Órdenes Militares, Calatrava, Cap. 43I- N 225.

ARCHIVO HISTÓRICO NACIONAL, Órdenes Militares, Registro de escrituras de la Orden de Calatrava III, Sign. 1343.

AYALA, C. de (1993) "Las fortalezas castellanas de la Orden de Calatrava en el siglo Xll". En la España Medieval, 16, Madrid, pp. 9-35.

AYALA, C. de (1996) "Las Órdenes Militares y la ocupación del territorio manchego (siglos XII - XIII)". IZQUIERDO, R. Y RUIZ, F. (Coord.) Alarcos 1 195. Actas del Congreso Internacional conmemorativo del VIII Centenario de la Batalla de Alarcos. Cuenca, pp. 47-104.

AYALA, C. de (1999) "Comendadores, encomiendas. Orígenes y evolución en las Órdenes Militares castellanos leonesas de la Edad Media". En FERNÁNDEZ, ICF. (Ed.) Ordens Militares. Guerra, religiâo, poder e cultura. Actas do III Encontro sobre Ordens Militares. Lisboa, pp. I0 I - 147.

AYALA, C. de (2003) Las órdenes militares hispánicas en la Edad Media (siglos XII-XV). Madrid.

BALLESTEROS, M. (1953) "La conquista de Jaén por Fernando III el Santo". Cuadernos de Historia de España. Instituto de Historia de España. Buenos Aires, pp. 63-1 38.

CANO CARRILLO, J. ; ALCÁZAR HERNÁNDEZ, EM. Y MONTILLA TORRES, I. ( 1994) "El molino fortificado del Cubo: Un molino hidráulico harinero del siglo XV". En Campaña juvenil de protección del Patrimonio Tecnológico de Andalucía. Sevilla, pp. 287-309.

CARRIAZO, J. de M. (194I) Hechos del Condestable D. Miguel Lucas de Iranzo. Madrid.

CASTILLO ARMENTEROS, JL. (1997) "Gran fortaleza". Alcaudete. En W.AA. Jaén pueblos y ciudades. Tomo I, Jaén, pp. $210-211$.

CASTILLO, JL. (2000) "La Orden de Calatrava en el Castillo de Alcaudete". En W.AA. Visitas al Patrimonio Histórico de Jaén 94 / 99, Colegio Oficial de Arquitectos de Jaén. Jaén, pp. 148 - 153.

CASTILLO, JL.; CASTILLO, JC.; SALVATIERRA, V. Y CHICA, P. (1999) "Diagnosis arqueológica en el Castillo de Sabiote (Jaén). Estudios preliminares a elaboración de un proyecto de restauración". Anuario Arqueológico de Andalucía 1994. Sevilla, Tomo III, pp. 278 - 285.

CASTILLO ARMENTEROS, JC. (1997) "Historia y Arqueología Medieval. Indicios de poblaciones". Lopera. En V.AA. Jaén, pueblos y ciudades. Tomo V. Diario Jaén, Jaén, pp. 177| - 1773.

CASTILLO, JC. (1997) "Un baluarte de la Orden de Calatrava". Torredonjimeno. En VV.AA. Jaén pueblos y ciudades, Tomo VI, Jaén, pp. 2497 - 2499.

CASTILLO, JC. (1997) "Pequeñas alquerías". Jimena. En V.AA. Jaén pueblos y ciudades. Tomo IV, Jaén, pp. I5701573.
CASTILLO, JC. (1998) "La conquista castellana del Alto Guadalquivir y la organización política: el realengo y el señorío bajo Fernando III". SALVATIERRA, V. (Ed.) Hispania, al-Andalus, Castilla. Jornadas Históricas del Alto Guadalquivir. Jaén, pp. 159 - 180.

CASTILLO, JC. Y CASTILLO, JL. (200I) "Aportaciones arqueológicas al estudio de las fortificaciones señoriales del Alto Guadalquivir (Jaén) entre los siglos XV y XVI". Mil anos de Fortificaçoes na Península Ibérica e no Magreb (500- 1500): Actas do Simposio Internacional sobre Castelos. Lisboa, pp. 719-732.

CASTILLO, JC:; CASTILLO, JL.; PÉREZ, MC. Y ALCÁZAR, EM. (1989) "Sistemas fronterizos en la Campiña Giennense". Arqueología Espacial, № 13, Fronteras, Teruel, pp. 207-2। 8.

CASTILLO, JC. Y CASTILLO, JL. ( 1997) "Castillo de Alcaudete". En V.AA. Los castillos a través de la historia. Jornadas Europeas de Patrimonio Histórico. Sevilla, pp. I42-145.

CASTILLO, JC.; LARA, JC. Y CASTILLO, JL. " La delimitación occidental del lqlim de Jaén: documentos escritos, Toponímia y Arqueología". III Congreso de Arqueología Medieval Española, Tomo II, Oviedo, pp. 369-376.

CASTILLO, J.C. Y ZAFRA, J. (I 994) "Alcaudete, un intento de proyecto integrado". VV.AA. Alcaudete en su historia. Alcaudete, pp. 13-25.

CEREZO, F. Y ESLAVA, J. (1989) Castillos y atalayas del Reino de Jaén. Jaén.

CHOCANO VAÑÓ, F. (200I) "Planos del Castillo y Casa Tercia de Lopera". En XII Jornadas Historia, Cultura y Sociedad de Lopera. Jaén, pp. 73-89.

CHUECA GOITIA, F. (197I) Andrés de Vandelvira, arquitecto. Jaén.

COOPER, E. (|99|) Castillos señoriales en la Corona de Castilla. Junta de Castilla y León.

CUEVAS, J. DEL ARCO, J. Y DEL ARCO, J. (200 I) Relación de los hechos del muy magnifico e mas virtuoso señor, el señor don Miguel Lucas muy digno Condestable de Castilla. Jaén.

DEL BARCO, A. (1987) 2000 Años de la fundación de la Colonia Augusta Gemina Tuccitana. Edición Facsímil. Excmo. Ayuntamiento de Torredonjimeno.

ESLAVA GALÁN, J. (1990) "El castillo de La Peña de Martos y la Orden de Calatrava". Boletín del Instituto de Estudios Giennenses, N 140, Jaén, pp. I49-160.

ESLAVA GALÁN, J. (1999) Los castillos de Jaén. Granada.

ESLAVA GALÁN, J. (1999) Castillos y atalayas del Reino de Jaén. Granada.

FLORES SÁNCHEZ, LF. (200I) "Molinos medievales fortificados, los grandes ignorados". En Actas del Congreso Internacional de Fortificaciones en el entorno del Bajo Guadalquivir. Alcalá de Guadaíra, pp. 247 - 253. 
GARCÍA FITZ, F. (1998) Castilla y León frente al Islam. Estrategias de expansión y tácticas militares (siglos XI XIII). Sevilla.

GARCÍA FITZ, F. (1998) "Pora acreçentamiento de nuestros regnos. Las funciones ofensivas de los castillos de frontera". En BARRIO, JA. Y CABEZUELO, JV. (Eds.) La fortaleza medieval. Realidad y símbolo. Murcia, pp. 75 - 89.

GARCÍA FITZ, F. (200I) "Guerra y fortificaciones en contextos de frontera. Algunos casos ibéricos de la Plena Edad Media". Mil anos de fortificaçoes na Península Ibérica e no Magreb (500-1 500): Actas do Simposio Internacional sobre Castelos. Lisboa (200I), pp. 519 - 532.

GONZÁLEZ IIMÉNEZ, M. (1993) "Algunas cuestiones en torno a los señoríos andaluces siglo XIII". En SARASA, E. Y SERRANO, E. (Eds.) Señorío y feudalismo en la Península Ibérica, I, Zaragoza, pp. 535 - 55 I.

GONZÁLEZ JIMÉNEZ, M. (1995) "La obra repobladora de Fernando III en los reinos de Jaén y Córdoba". Fernando III y su época. Actas de las IV Jornadas Nacionales de Historia Militar. Sevilla, pp. 287 - 312.

GONZÁLEZ JIMÉNEZ, M. (2000) "El final de la expansión: Las Órdenes Militares en Andalucía (1225 - 1350)". En IZQUIERDO, R. Y RUIZ, F. Las órdenes militares en la Península Ibérica. Volumen I: Edad Media. Cuenca, pp. 6II-634.

GONZÁLEZ, T. (1833): Colección de privilegios, franquezas, exenciones y fueros, concedidas a varios pueblos y corporaciones de la Corona de Castilla, copiadas de orden de S.M. de los registros del Real Archivo de Simancas. IV Madrid.

GONZÁLEZ, J. (1946) "La conquistas de Fernando III en Andalucía". Hispania, № XXV, Madrid, pp. 5I5-605.

GONZÁLEZ, J. (195I) El repartimiento de Sevilla. I. Madrid.

GONZÁLEZ, J. (1980) Reinado y diplomas de Fernando III. Córdoba.

HORNOS, F.; SALVATIERRA, V. Y CHOCLÁN, C. (1987) "Actividad de limpieza, consolidación y sondeos estratigráficos en la explanada frente al Castillo de Sabiote. Jaén". Anuario Arqueológico de Andalucía 1986, Sevilla, Tomo III, pp. 210 - 215.

IZQUIERDO; R. ( 1995): "El poblamiento en La Mancha en el siglo XIl”. ZOZAYA, J. (Ed.) Alarcos' 95. El fiel de la balanza. Junta de Comunidades de Castilla - La Mancha, pp. 99-1 12.

IZQUIERDO, R. (2000)"El espacio de las Órdenes Militares: planteamientos para un análisis arqueológico". IZQUIERDO, R. Y RUIZ, F. Las Órdenes Militares en la Península Ibérica. Volumen I: Edad Media, Cuenca, pp. 33-56.

LIZCANO, R. ( 1993):"'Memoria de excavación arqueológica: Castillo de Torredonjimeno (Jaén). Campaña de 1990". Anuario Arqueológico de Andalucía 1991, Tomo III, Cádiz, pp. 292-304.
LIZCANO, R.; AGUAYO, M.; ARAQUE, D.; HERNÁNDEZ, M.; IZQUIERDO, M. Y RUIZ, J. (I993):" $2^{a}$ Campaña de excavaciones arqueológicas en el Castillo de Torredonjimeno (Jaén)". Anuario Arqueológico de Andalucía 1991, Tomo III, Cádiz, pp. 305 - 310

MARTÍNEZ ANTUÑA, M. (1932) "Conquista de Quesada y Alcaudete, por Muhammad II de Granada". Religión y Cultura, 20 (1932), pp. 386-395.

MATELLANES, JV. (200I): "Las fortalezas de Segura de la Sierra: aproximación a un marco de organización del espacio (I 235- I 350)". Actas del IV Curso de Cultura Medieval. Seminario: La fortificación Medieval en la Península Ibérica. Aguilar de Campoo, pp. 213 - 218.

MATELLANES MECHAN, JV. (1994). "El realengo en Alcaudete (13 |2-1385)". Alcaudete en su historia. Excmo. Ayuntamiento de Alcaudete. (Alcaudete, Jaén), pp. |8|190.

MEDINA CASADO, M. Y PANTOJA VALLEJO, JL. (1996) Apunte histórico de Lopera. Lopera.

MENDOZA GARRIDO, JM. (1996) "El sistema de encomiendas en la Orden de Calatrava (ss. XII-inicios del XIII)". IZQUIERDO, R. Y RUIZ, F. (Coord.) Alarcos I 195. Actas del Congreso Internacional conmemorativo del VIII Centenario de la Batalla de Alarcos. Cuenca, pp. 315 - 329.

MENÉNDEZ PIDAL, R. (1955) Primera crónica General de España. Madrid.

MERCADO EGEA, J. (1997) Santisteban del Puerto. Historia y Diplomática hasta finales del s. XV. Jaén.

MOLERO, JM. (1993): "Sistemas de defensa y control en el Campo de San Juan: del dominio musulmán al cristiano (siglos X-XIII)". IV Congreso de Arqueología Medieval Española, Tomo II, Alicante, pp. 400-402.

MONTES NIETO, F. (1993) La Orden de Calatrava en la Villa de Porcuna (15/5-1558). Porcuna.

ORTEGA, II. de; ALVÁREZ, JF. Y ORTEGA, P. de (|76|) Bullarium Ordinis Militiae de Calatrava. Barcelona, Edic. El Albir, 1981.

PANTOJA VALLEJO, J.L. ( 1993) "El castillo-fortaleza de Lopera. Apuntes para su historia". IV Jornadas sobre Historia de Lopera. Jaén, pp. 31 - 52.

RADES Y ANDRADA, F. de (I752) Crónica de la Orden Militar de Calatrava, Toledo.

RIVAS MORALES, A. (1992) Historia de Alcaudete. Granada.

RIVAS MORALES, A. (1994) "El señorío en Alcaudete: origen y constitución del mismo". VV.AA. Alcaudete en su historia. Alcaudete, pp. 197-206.

RODRÍGUEZ MOLINA, J. (1974-75) "Las Ordenes Militares de Calatrava y Santiago en el Alto Guadalquivir (siglos XIII - XV)". Cuadernos de Estudios Medievales, IIIII, Granada, pp.. 59 - 83. 
RODRÍGUEZ MOLINA, J. (1978) El reino de Jaén en la Baja Edad Media. Aspectos demográficos y económicos. Granada.

RODRÍGUEZ MOLINA, J. ( 1982) "Jaén. Organización de su tierra y hombres (siglos XIII - XVI)". WV.AA. Historia de Jaén. Jaén, pp. 204 - 263.

RODRÍGUEZ MOLINA, J. (1996) La vida de la ciudad de Jaén en tiempos del Condestable Iranzo. Jaén.

RODRÍGUEZ-PICAVEA MATILLA, E. (1990). "Génesis y evolución del señorío calatravo en la villa de Alcaudete". En WV. AA. Alcaudete en su historia. Alcaudete, pp. I57179.

RODRÍGUEZ-PICAVEA, E. (1994) La formación del feudalismo en la meseta meridional castellana. Los señoríos de la Orden de Calatrava en los siglos XII-XIII. Madrid.

RODRÍGUEZ-PICAVEA MATILLA, E. (1994). “Un ejemplo de aculturación cristiano-feudal en la frontera nazarí. La Orden de Calatrava en Alcaudete". Actas del II Congreso de Historia de Andalucía. Historia Medieval. Córdoba.

RODRÍGUEZ-PICAVEA, E. (200I) "Fortalezas y organización territorial en el Campo de Calatrava (siglos XIIXV)". Actas do Simposio Internacional sobre Castelos. Mil anos de fortificaçoes na Península Ibérica e no Magreb (500-1 500). Lisboa, pp. $623-632$.

RUIZ CALVENTE, M. (1989) "El castillo-palacio de la Villa de Sabiote (Jaén). Estudio histórico artístico". Revista Castillos de España, Nº 98, pp. 17 - 30.

RUIZ CALVENTE, M. (1990) "Aportación documental sobre las fortalezas calatravas de Porcuna, Lopera, Arjona, Arjonilla e Higuera de Arjona; años |459-| 494". Aspectos geográficos e históricos de la ciudad de Andújar y su comarca. Granada, pp.| 30 - |5|.

RUIZ POVEDANO, JM. (1980) "Poblamiento y Frontera. La política repobladora de Alfonso XI en la villa de Alcaudete". Boletín del Instituto de Estudios Giennenses, 101, Jaén, pp. $65-76$.
SALVATIERRA CUENCA, V. (Ed.) (1995) Guía arqueológica de la Campiña de Jaén. Granada.

SALVATIERRA, V. Y CHOCLÁN, C. ( 1986 ) "Excavaciones arqueológicas en Jaén. Sabiote". V Coloquio Internacional de Historia Medieval de Andalucía. Córdoba, pp. 787-790.

SOLANO, E. (1978) La Orden de Calatrava en el siglo XV. Sevilla.

TORAL, E. (1987) Jaén y el Condestable Miguel Lucas de Iranzo. Jaén.

VALDECANTOS, (1998) Castillos de Jaén. Descubre el pasado de una tierra fronteriza. León.

VALERA, E. (1996-1997) "La estructura castral Santiaguista en la Sierra de Segura durante el siglo XIII: aproximación a su tipología". Historia Medieval. Anales de la Universidad de Alicante, II, Alicante, pp. 587 - 598.

VALLVÉ BERMEJO, J. (1969) "La división territorial en la España musulmana. La Cora de Jaén". Al-Andalus, Nº 34, pp. $55-82$.

VANDERFORD, K.H. (Ed.) (1984) Setenario. Barcelona.

VILLEGAS, LR. (1991) "Las estructuras de poder de la Orden de Calatrava. Una propuesta de análisis". Historia, Instituciones y Documentos, I8, Sevilla, pp. 467 - 504.

VILLEGAS DÍAZ, LR. Y GARCÍA SERRANO, R. (1976) "Relación de los pueblos de Jaén, ordenadas por Felipe II". Boletín del Instituto de Estudios Giennenses, № 87, Jaén, pp. 9 - 302.

XIMENA JURADO, M. de. Antigüedades de Jaén. Manuscrito $n^{\circ} 1.080$ de la Biblioteca Nacional, Madrid. 


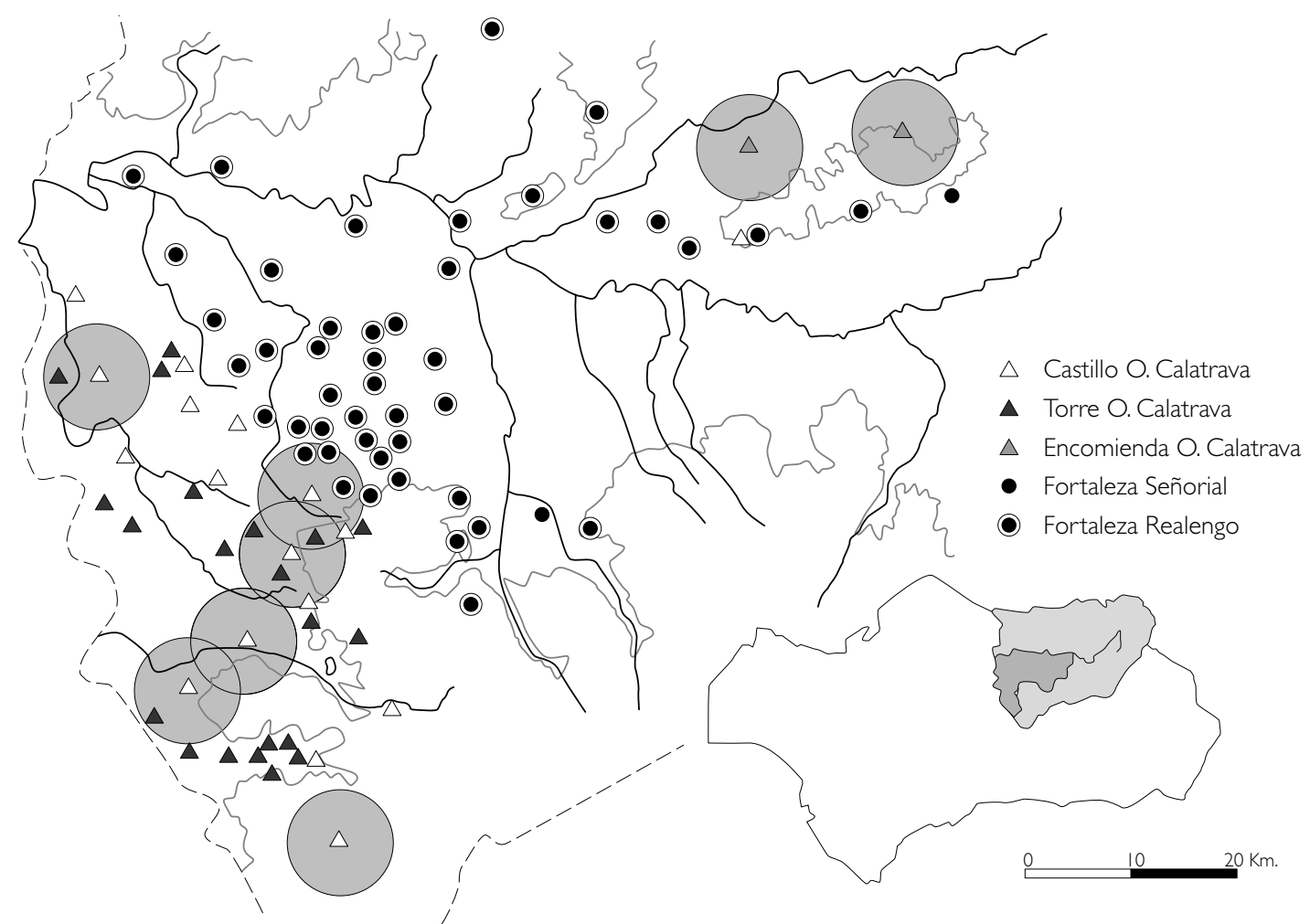

Fig. I. Fortalezas Orden de Calatrava S. XIII

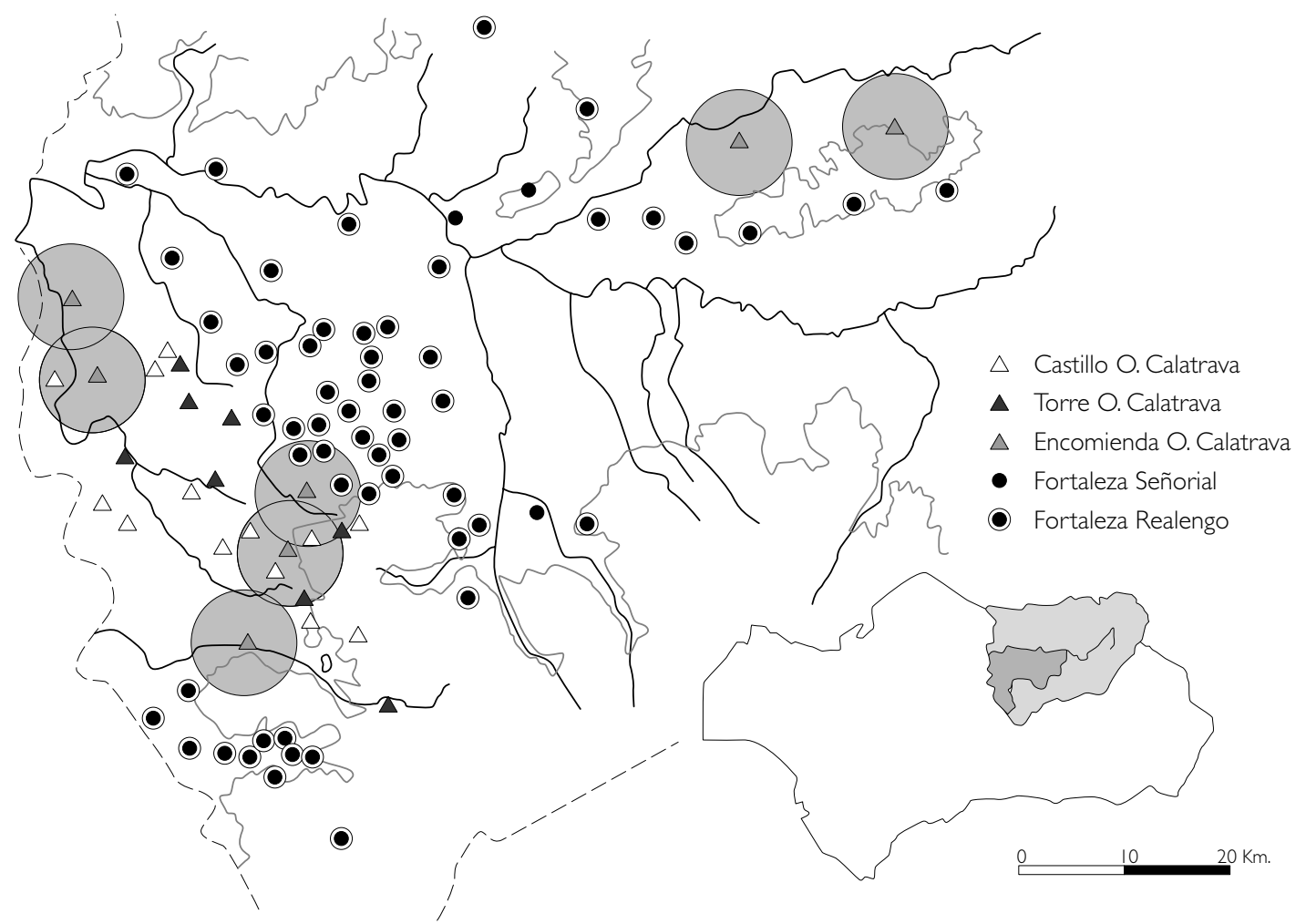

Fig. 2. Fortalezas Orden de Calatrava S. XIV 


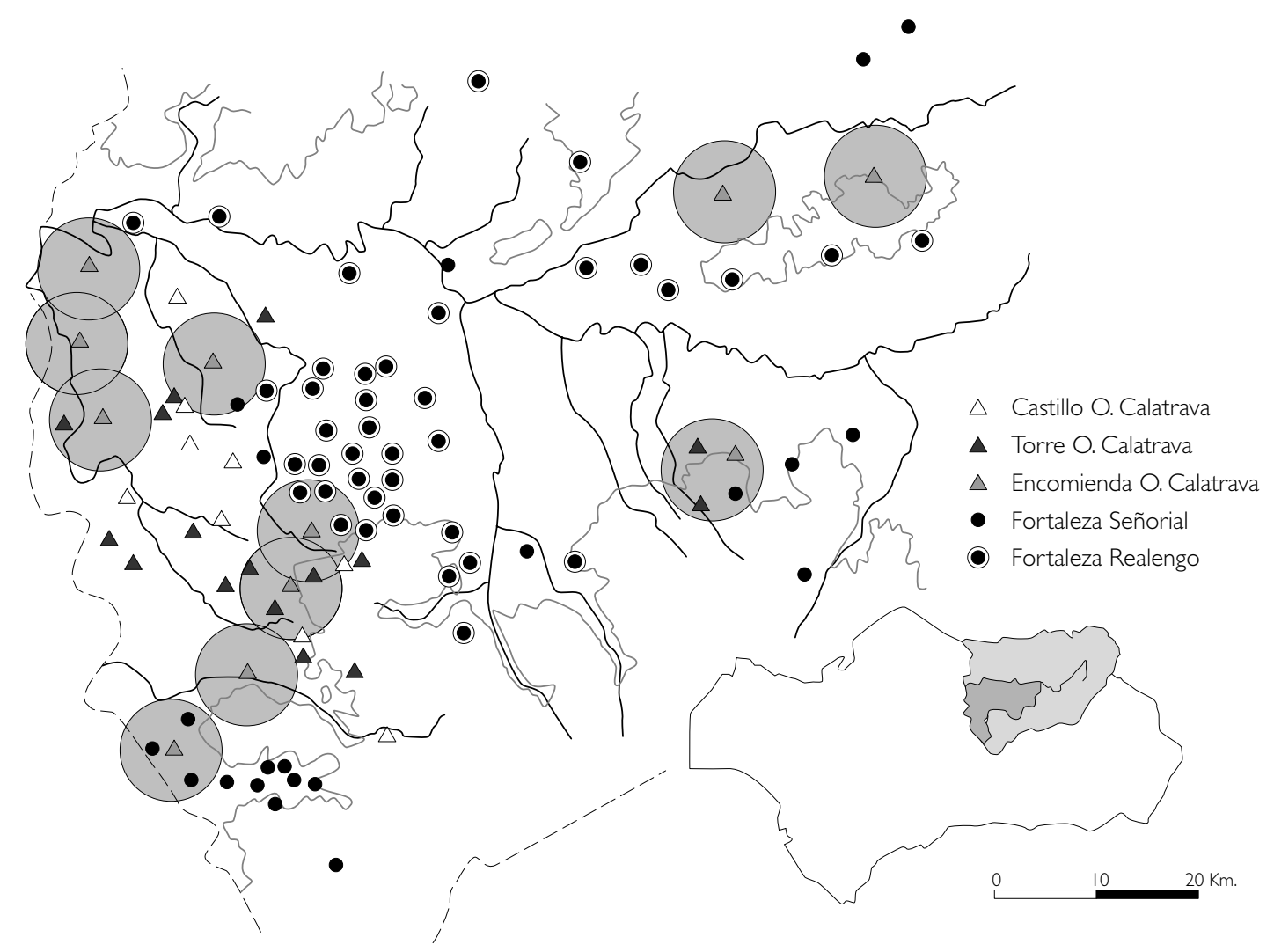

Fig. 3. Fortalezas Orden de Calatrava S. XV

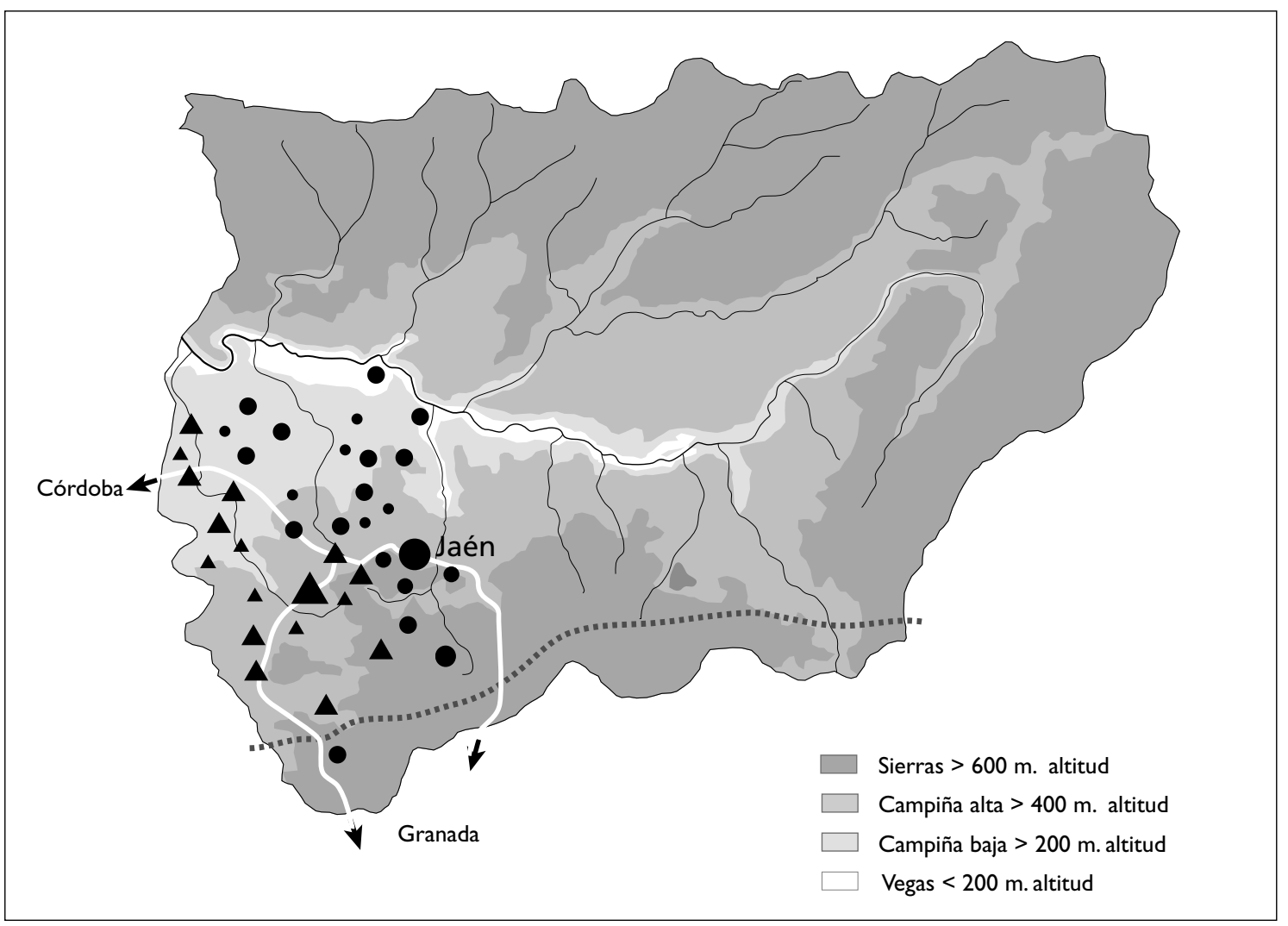

Fig. 4. Fortalezas y vías de comunicación 


\section{Benciated}

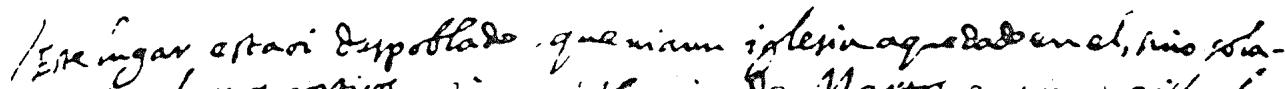

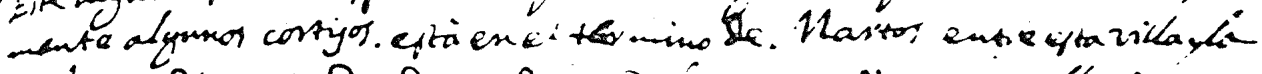

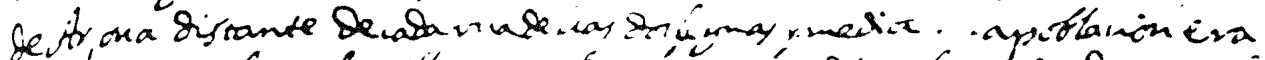

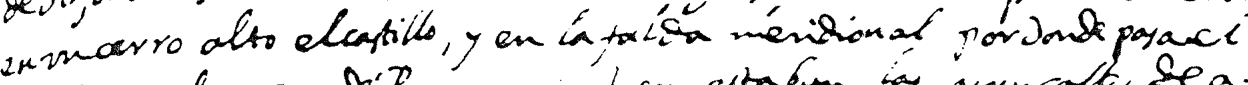

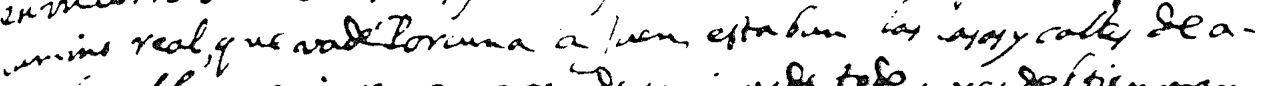

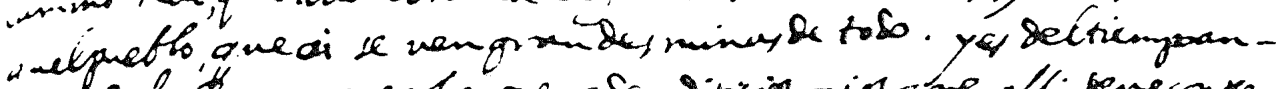

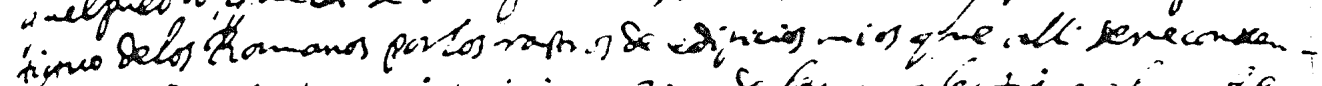

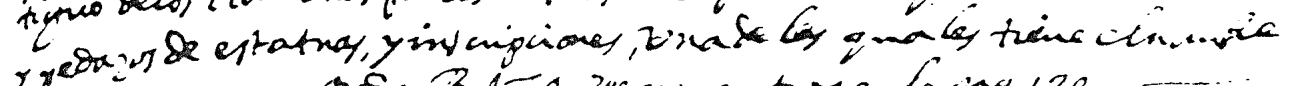

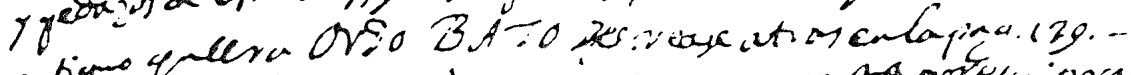

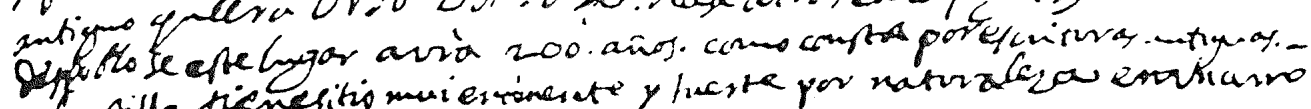

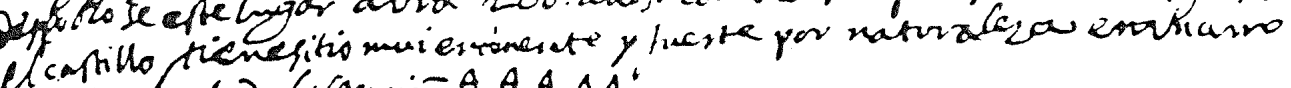

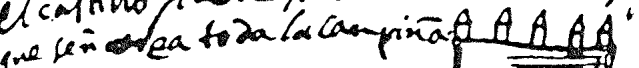

$$
1
$$

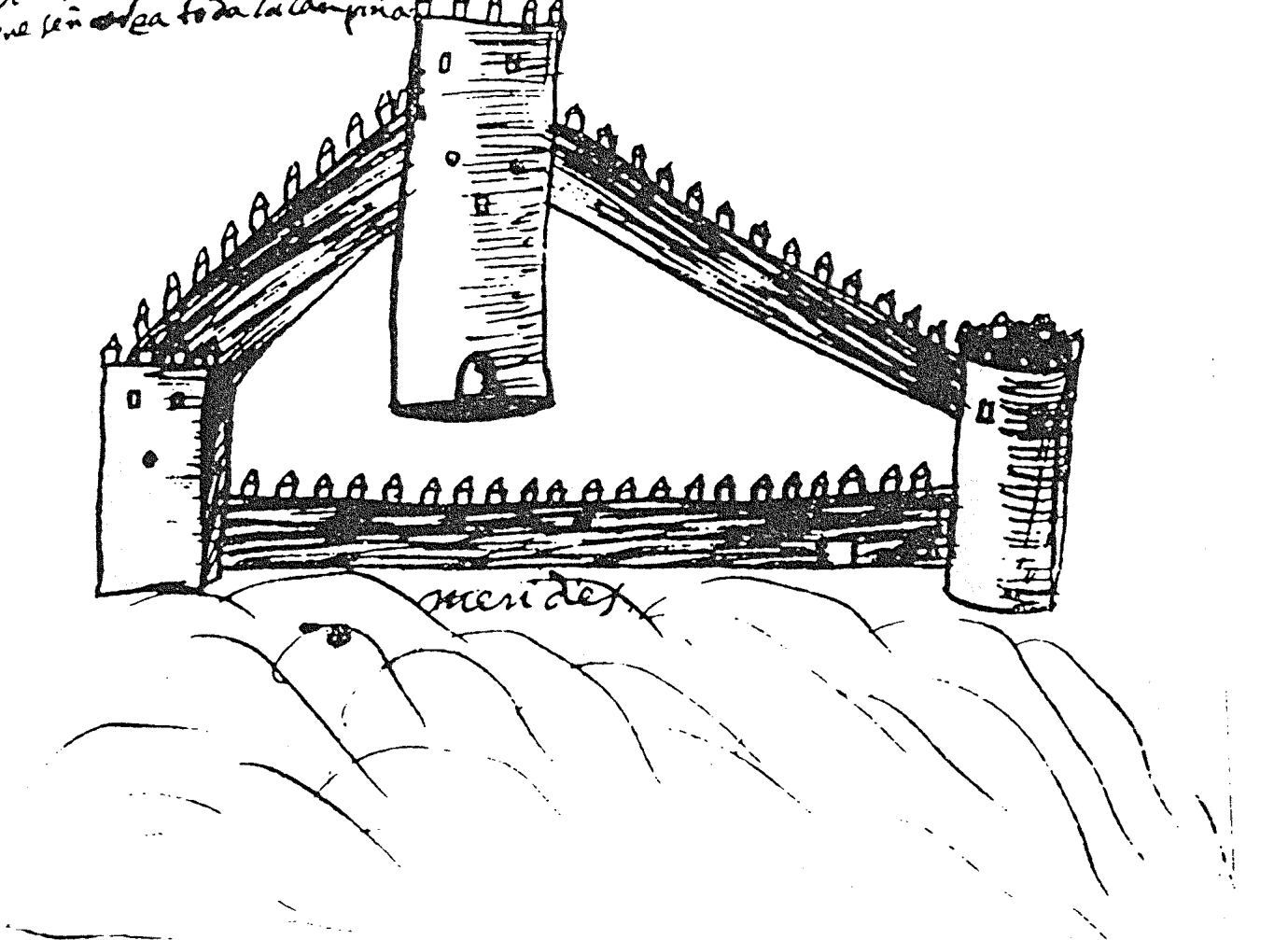

Fig. 5. Castillo de Torrebençala según Ximena Jurado 


\section{Cotrufes:}

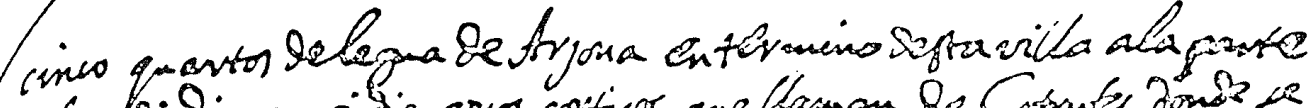

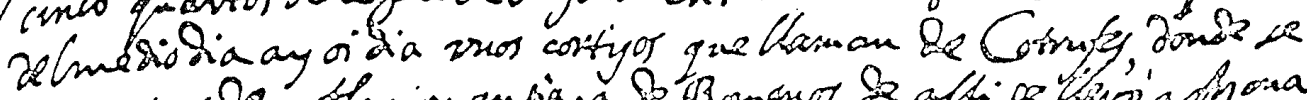

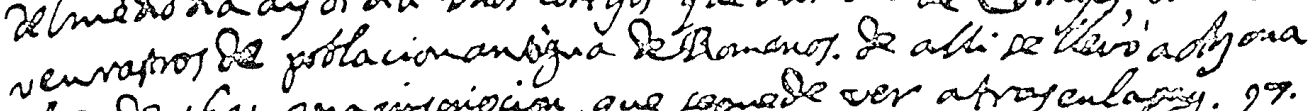

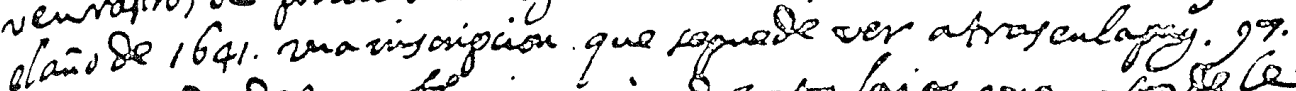

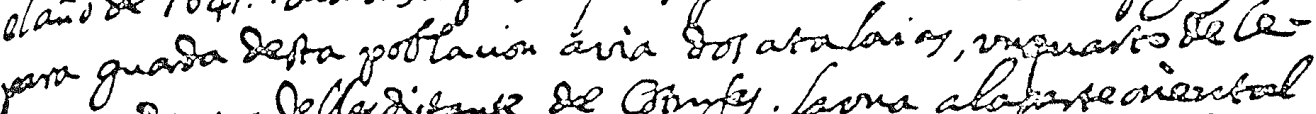

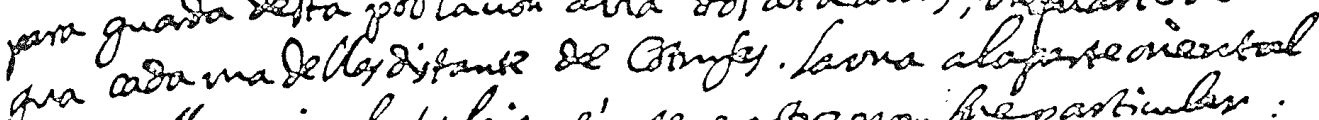

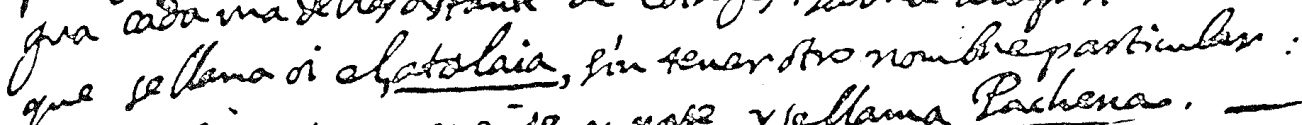

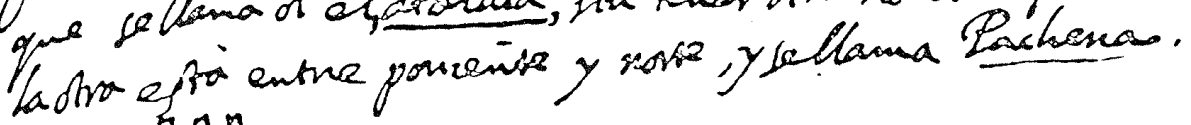
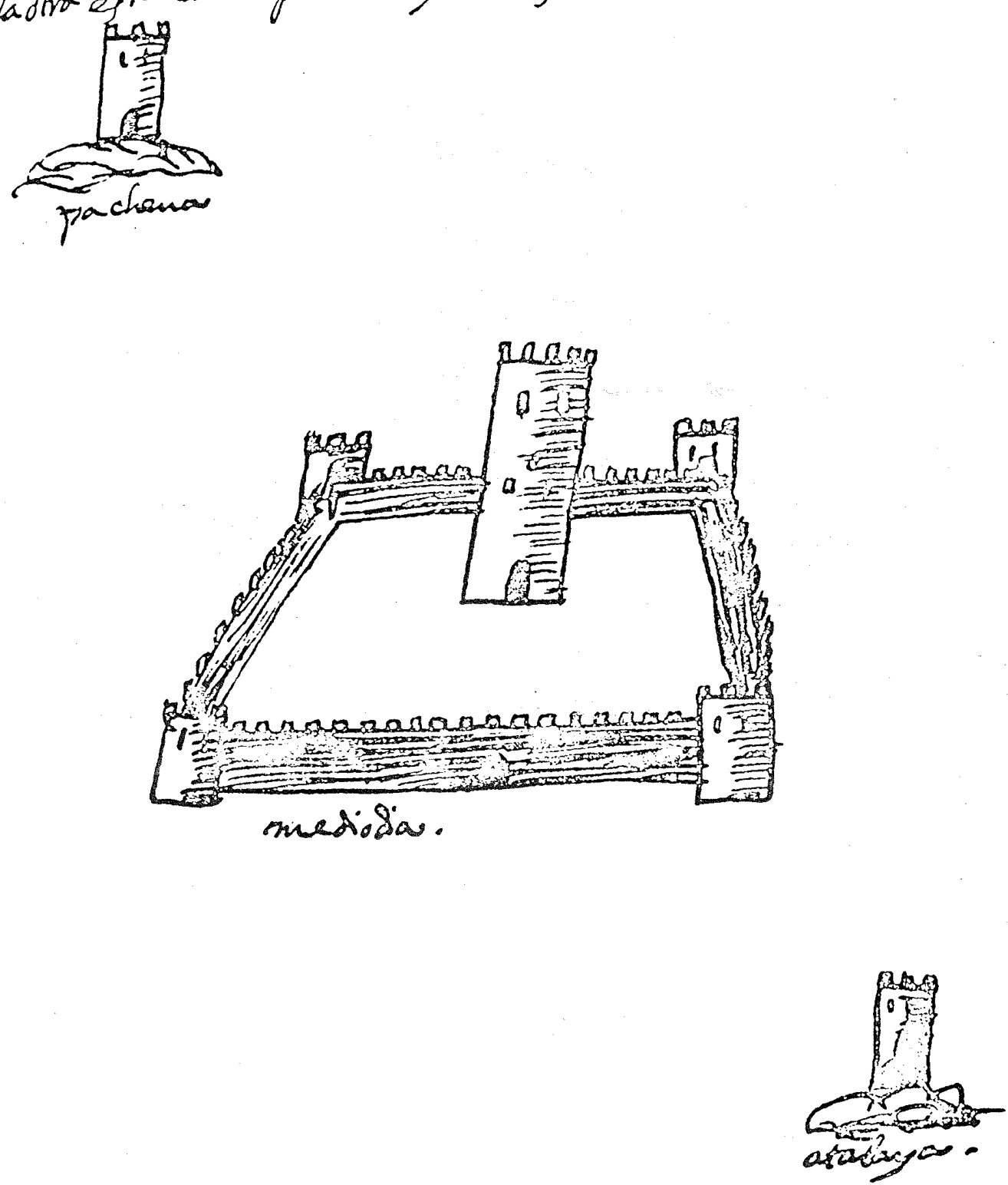

Fig. 6. Castillo de Cotrufes según Ximena Jurado 


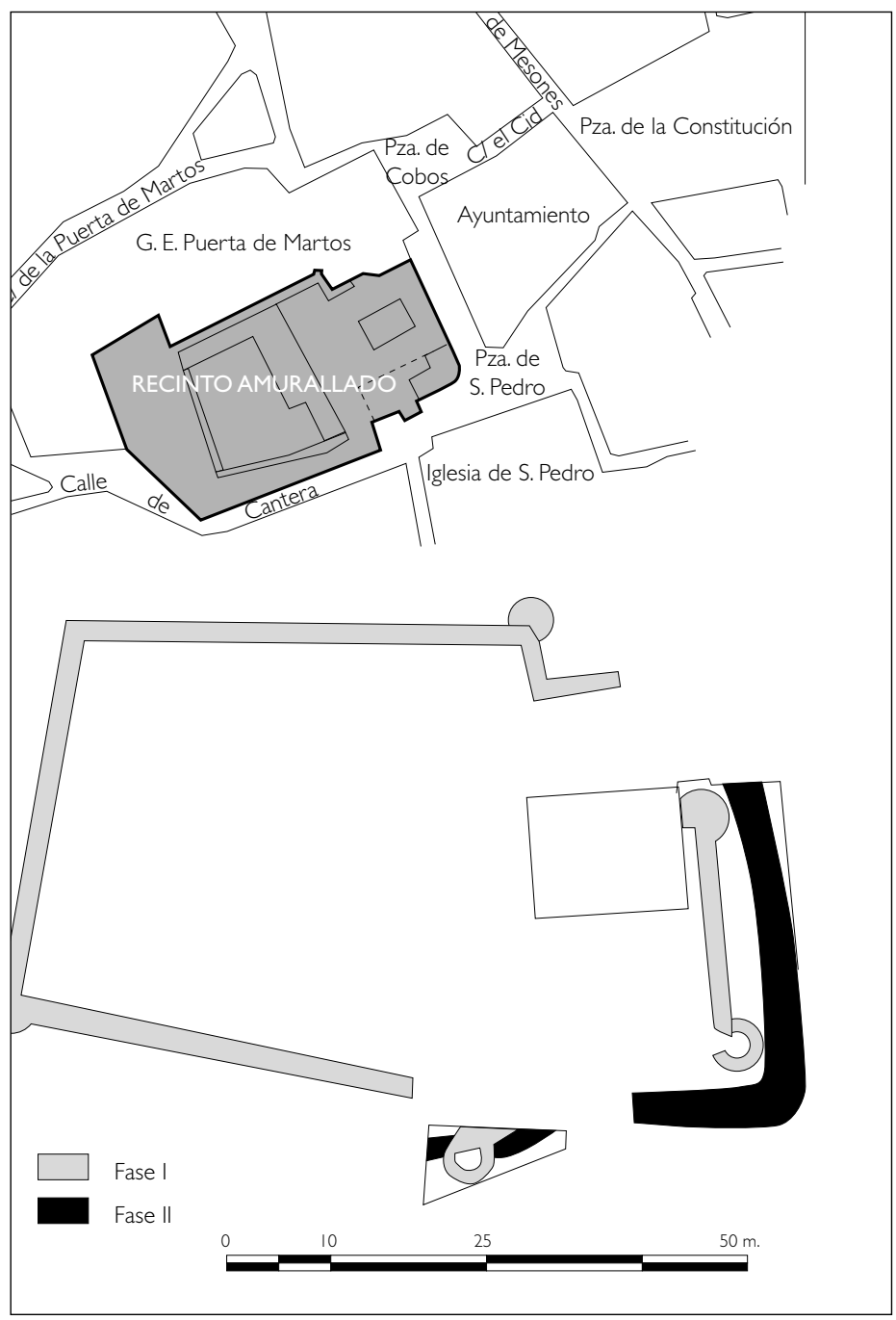

Fig. 7. Castillo de Torredonjime-

no según R. Lizcano

Fig. 8. Reconstrucción del Castillo de Torredonjimeno

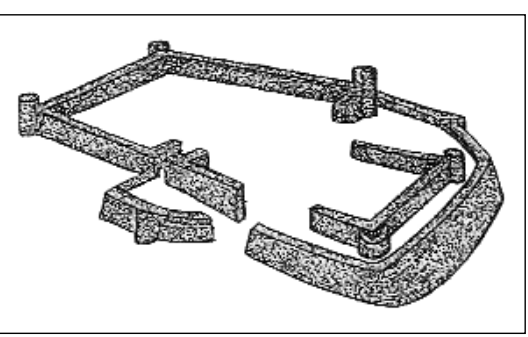

Fig. 9. Planta de Torre Circular del Castillo de Torredo

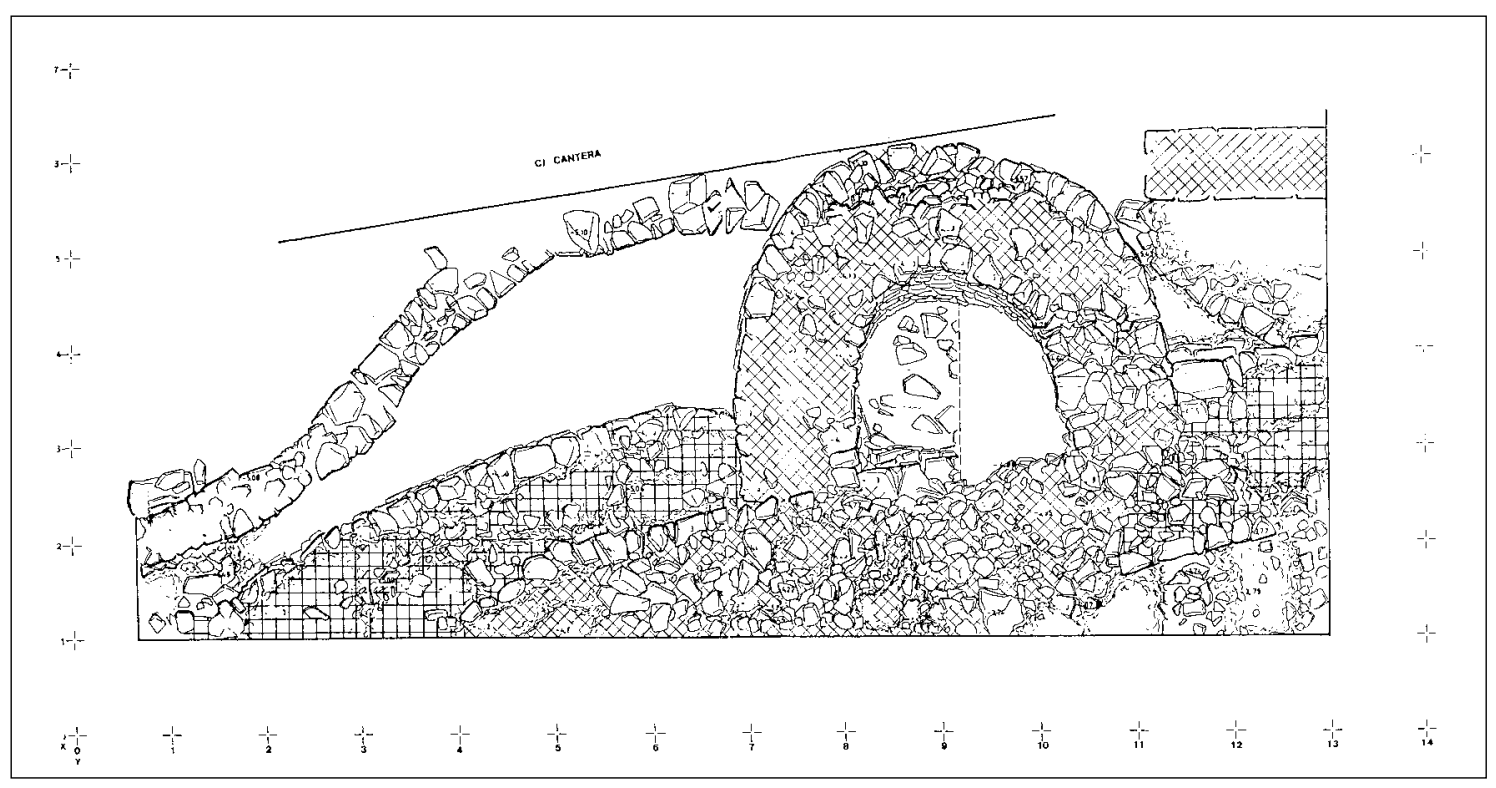




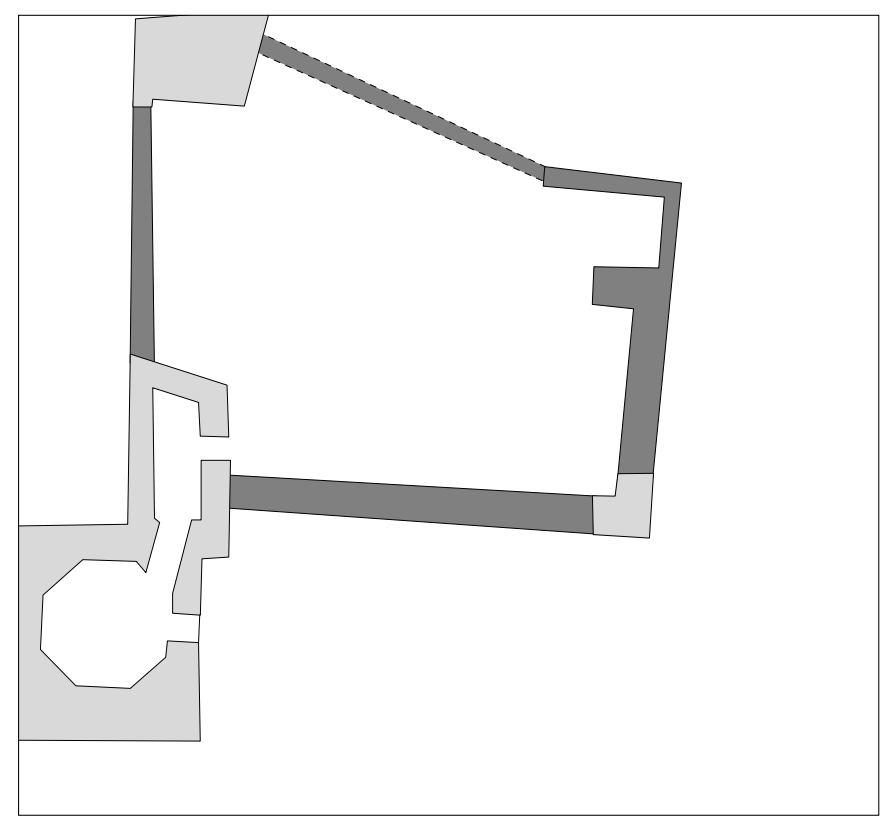

Fig. I0. Castillo de Jimena

Fig. I I. Recinto

Amurallado de Porcuna según V. Salvatierra

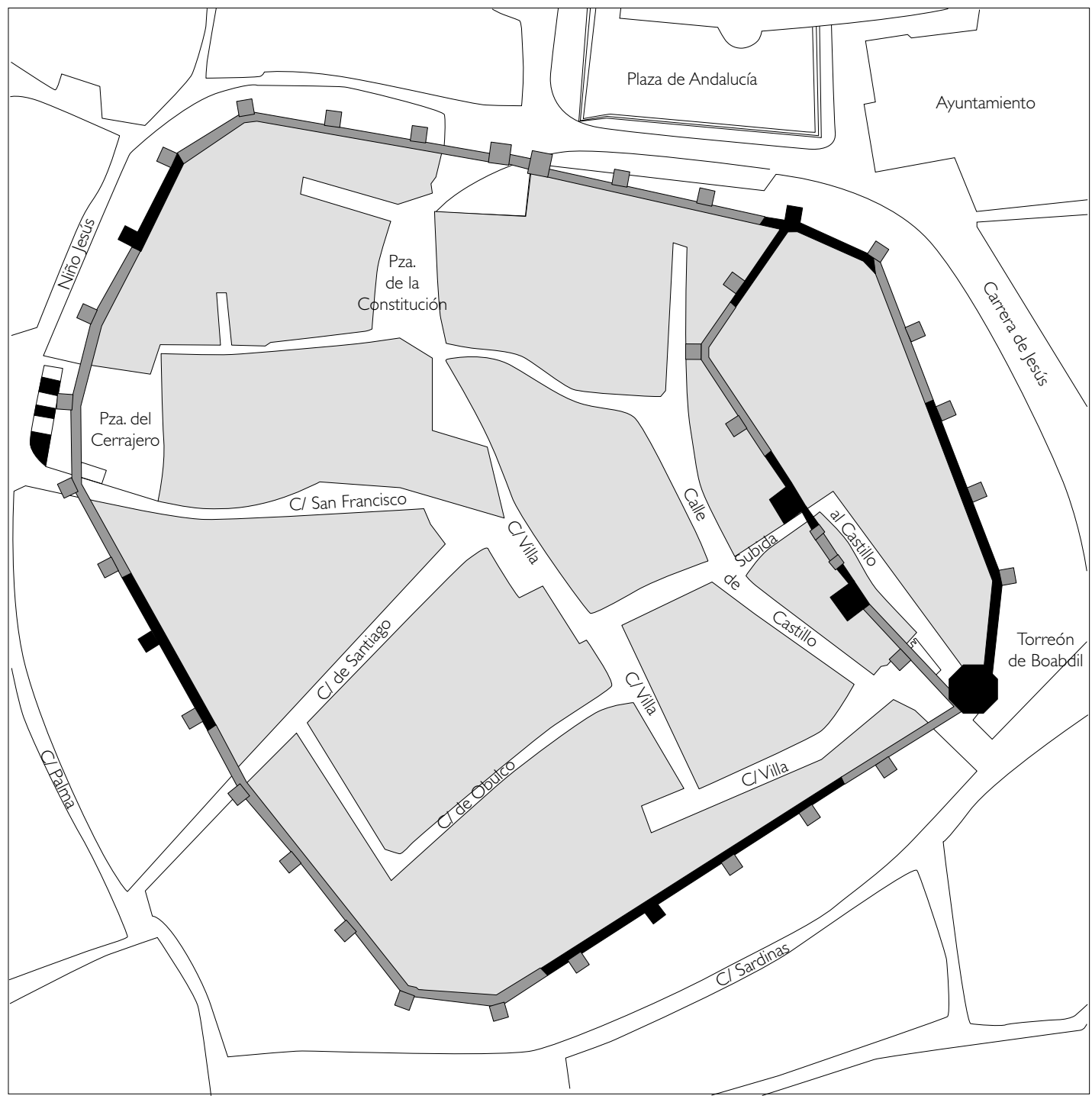




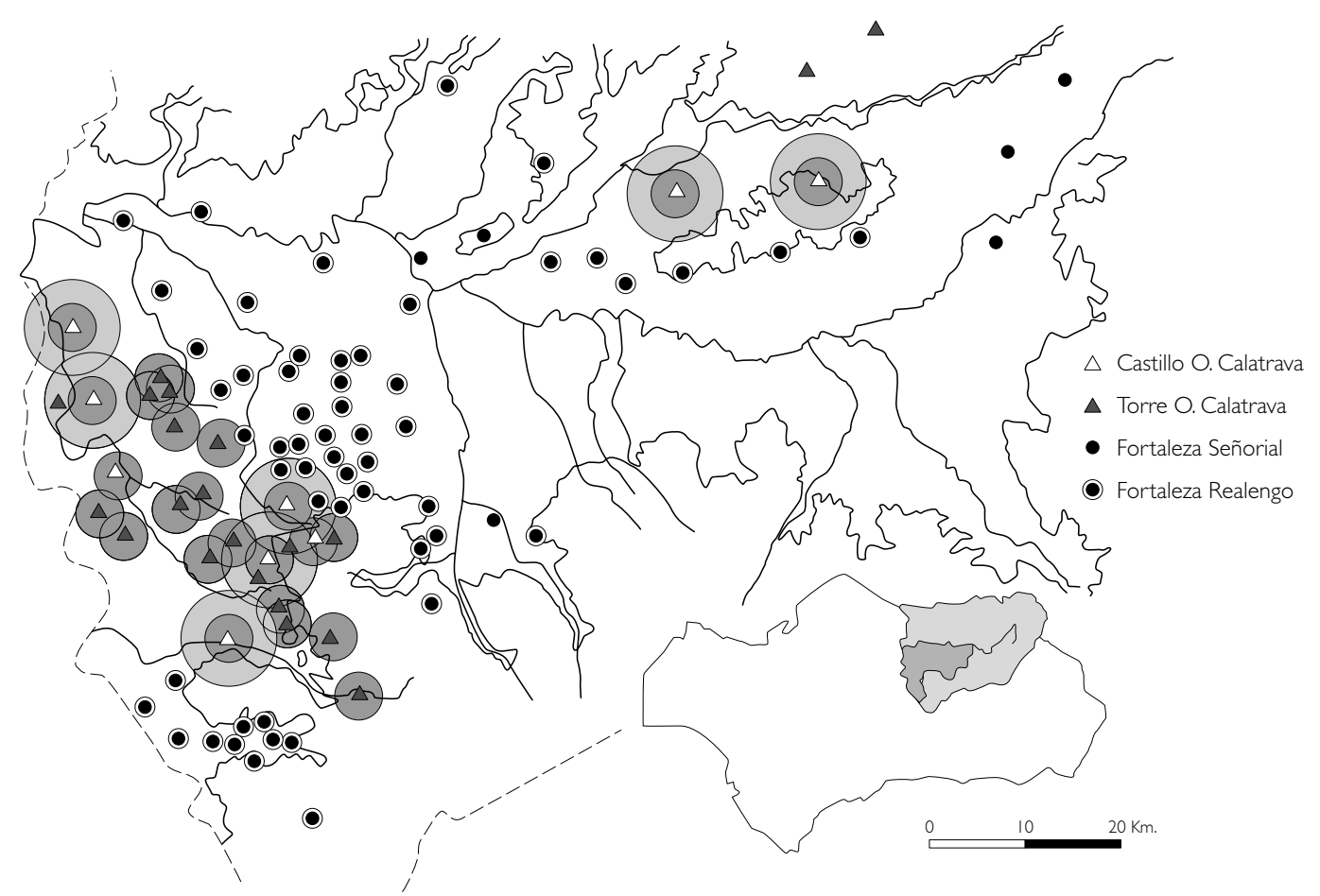

Fig. 12. Control Visual de las fortalezas Calatravas.

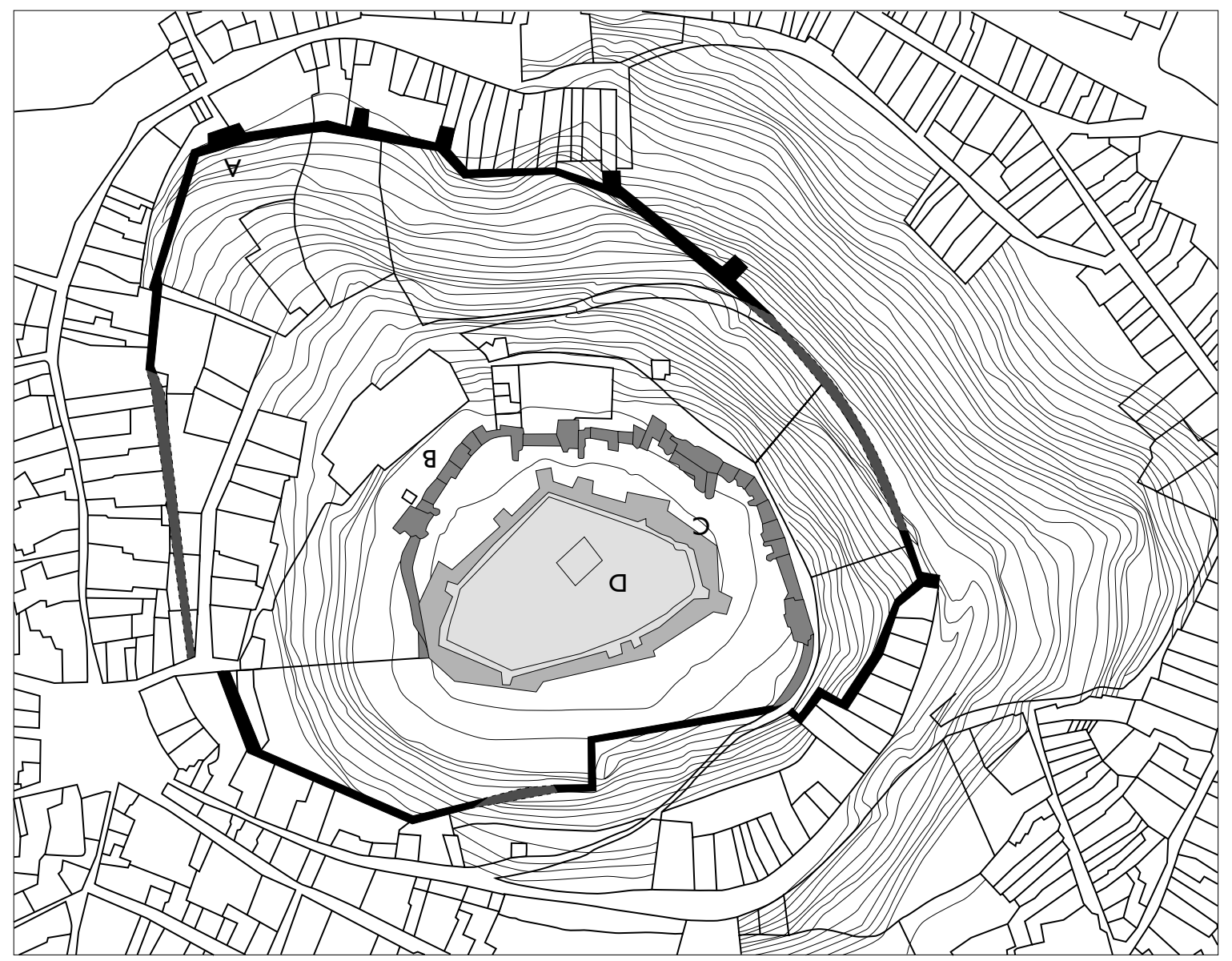

Fig. 13. Estructuras defensivas de la Villa de Alcaudete 


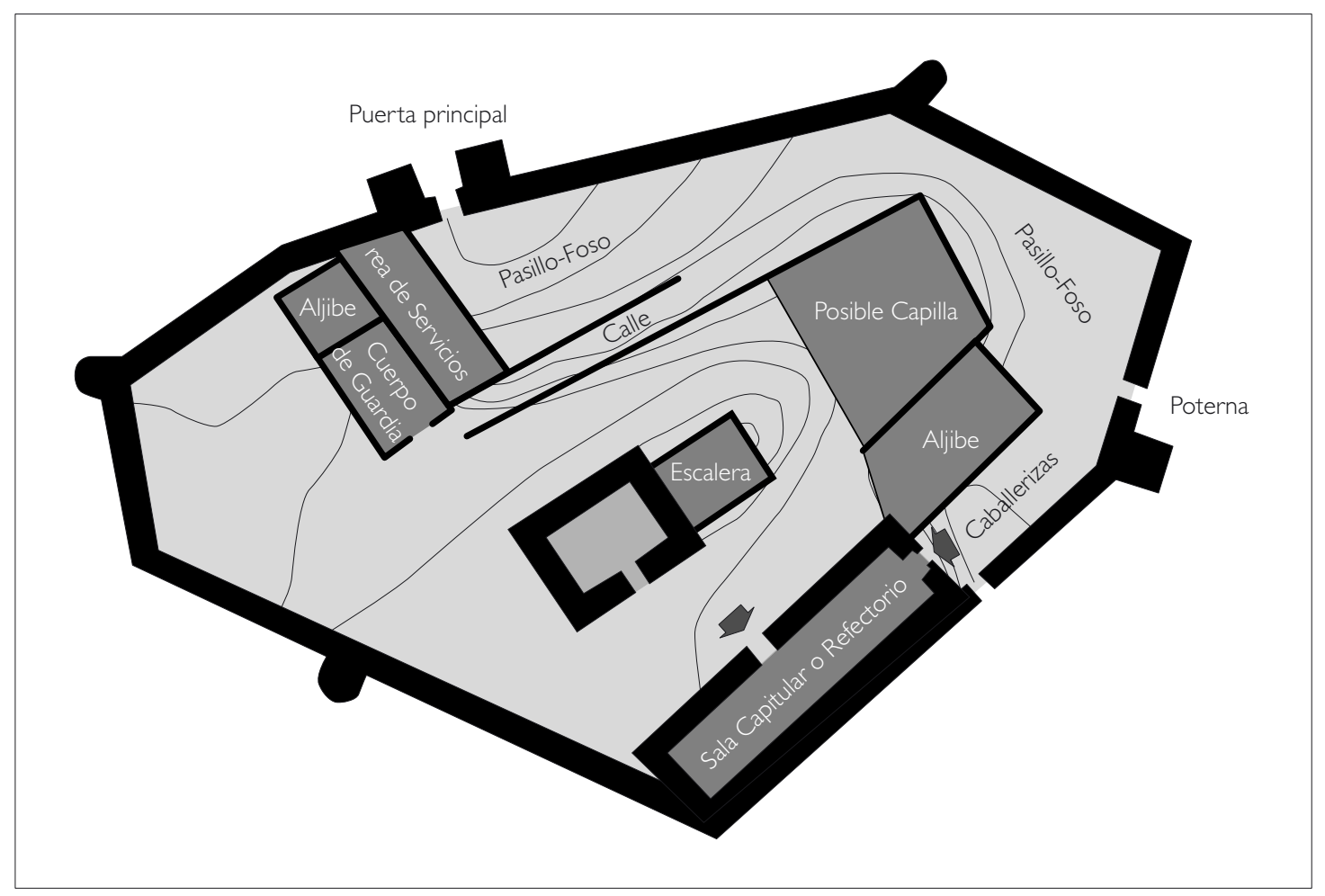

Fig. 14. Castillo de Alcaudete

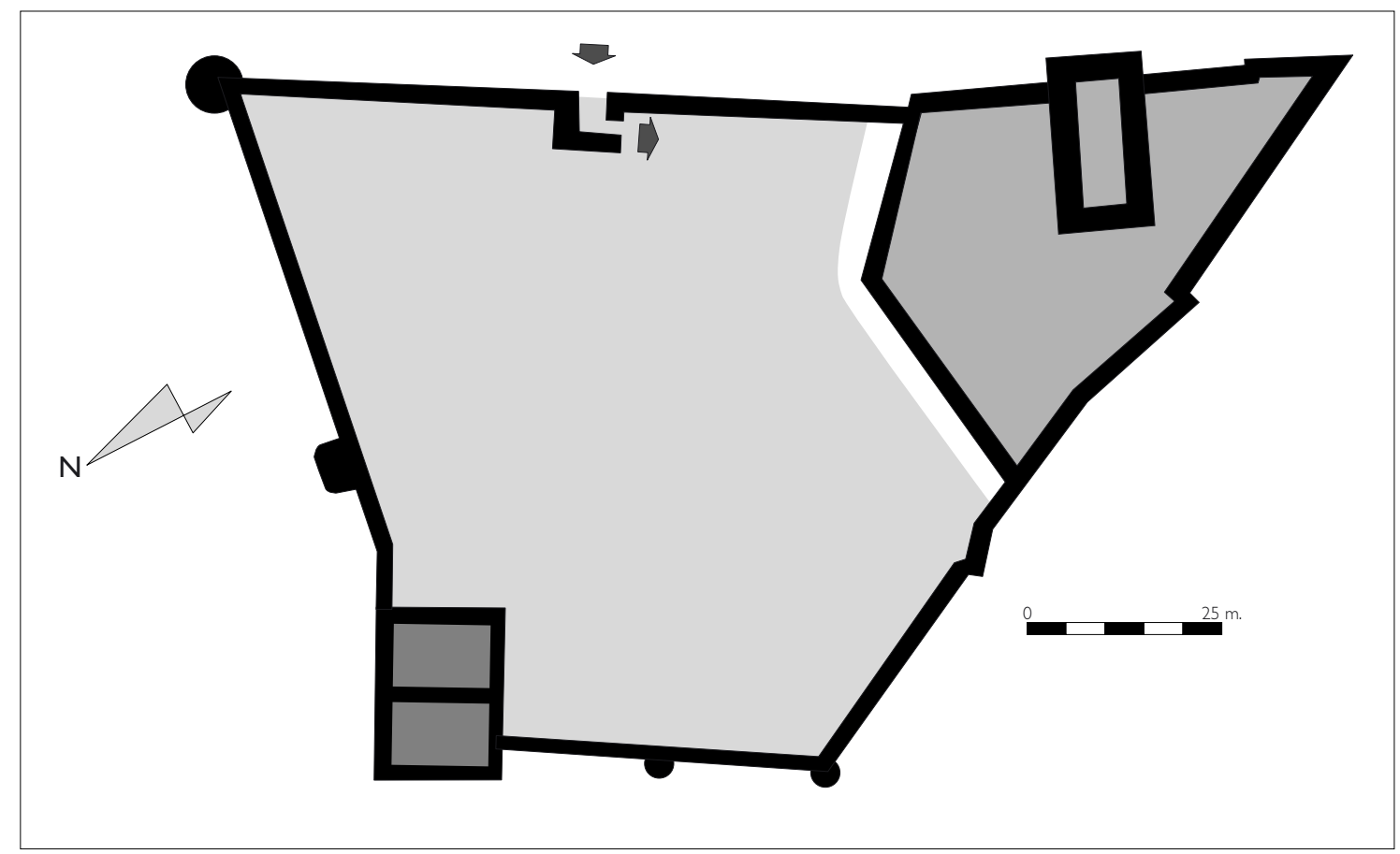

Fig. 15. Castillo de la Peña de Martos según J. Eslava (1990). 


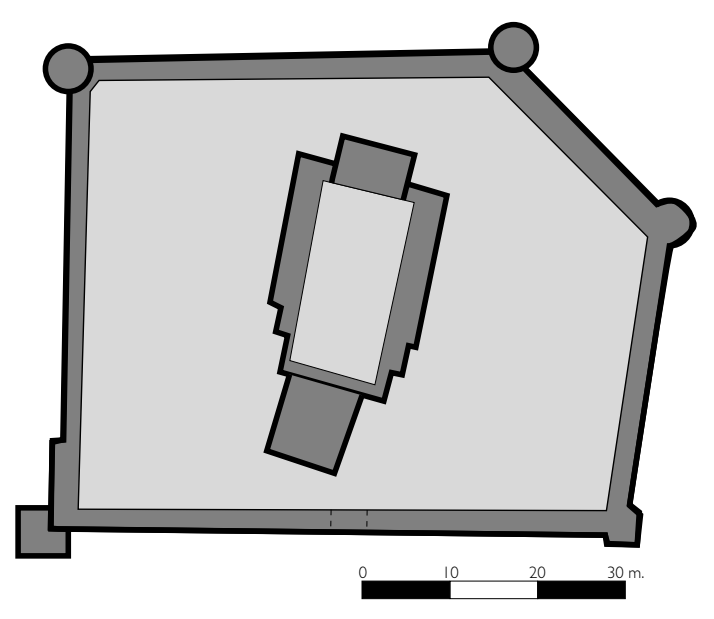

Fig. 16. Castillo de Lopera

según F. Chocano (200I)

Fig. I7. Alcázar de la Fortaleza de Lopera según F. Chocano
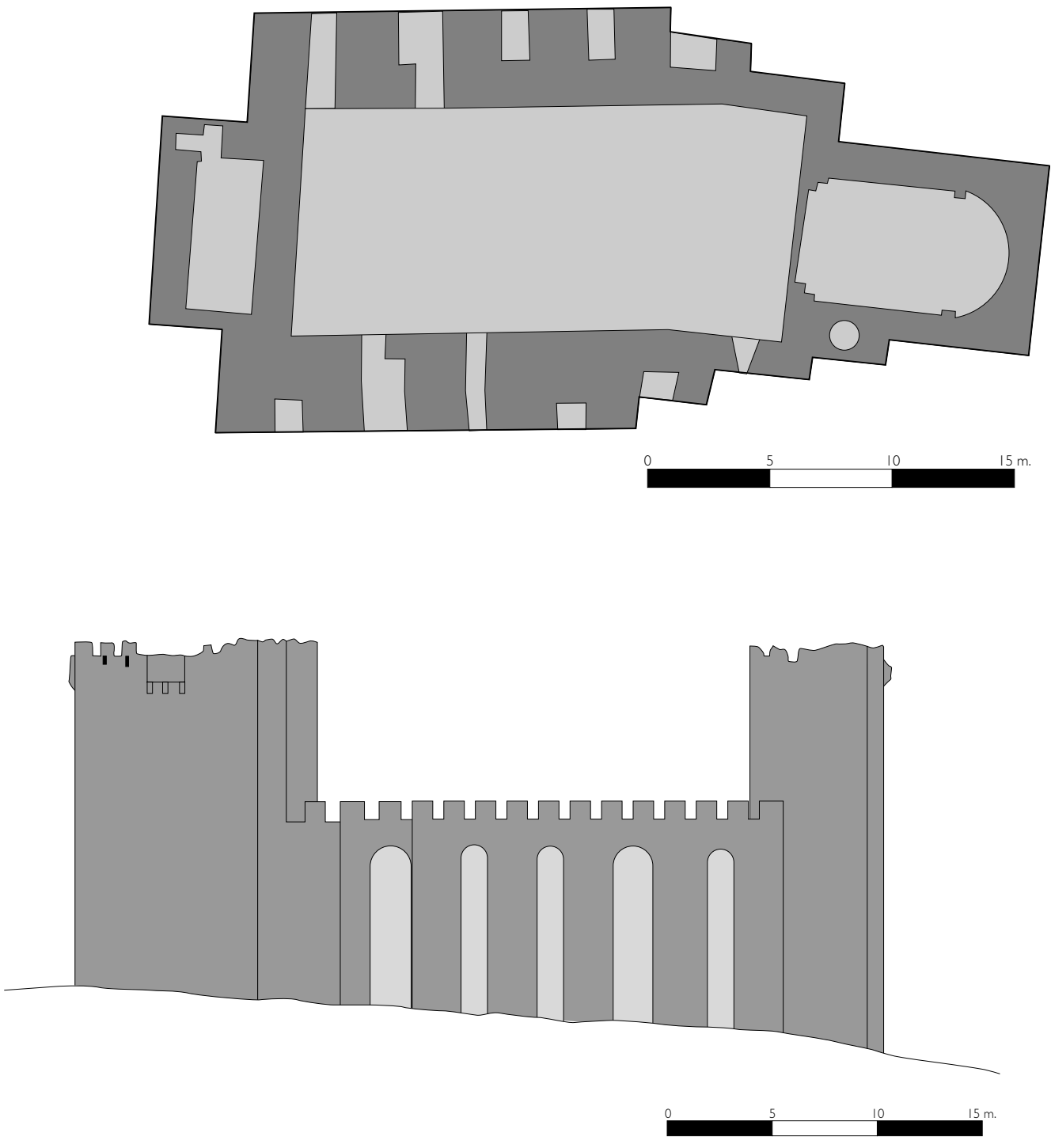

Fig. 18. Alcázar de la Fortaleza de Lopera según F. Chocano 


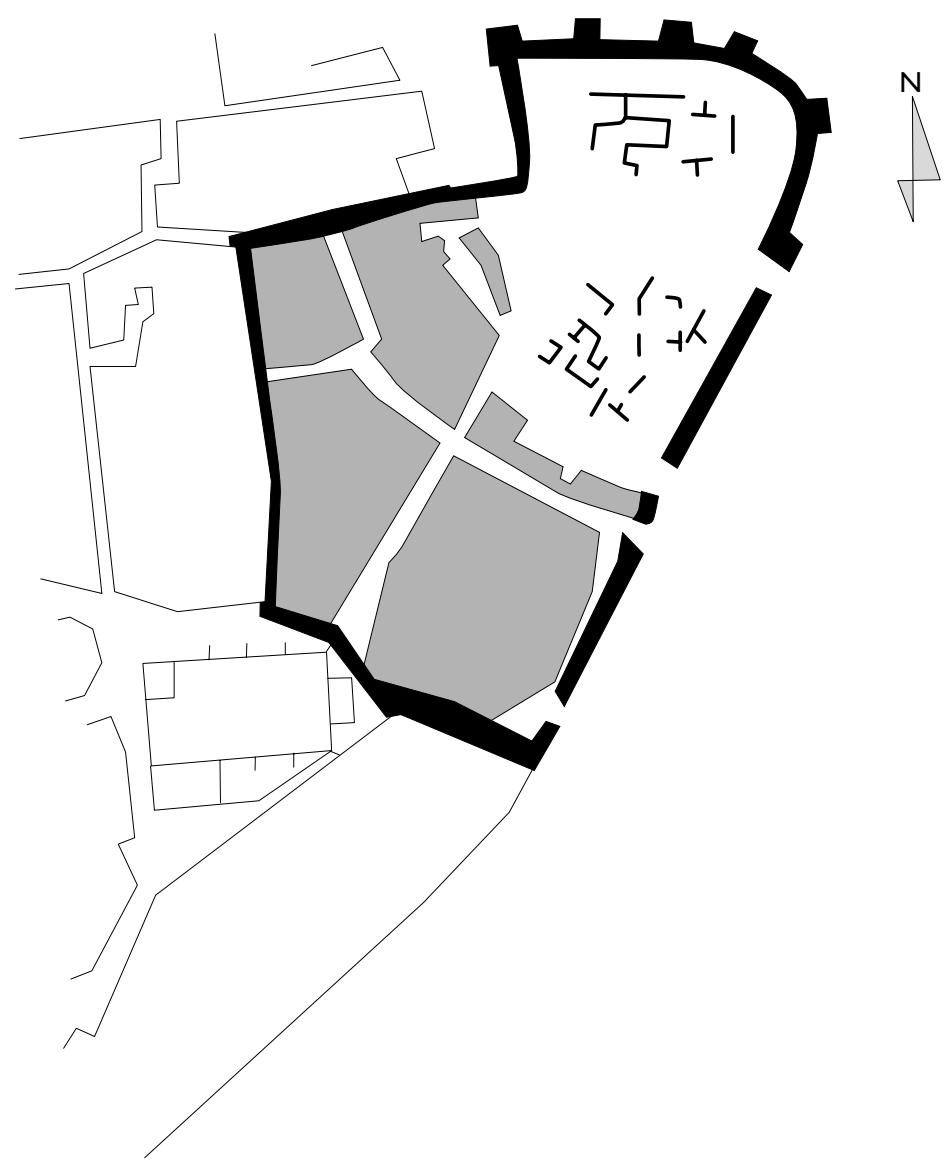

Fig. 19. Hișn Sabiyūto (s. VIII - XII)

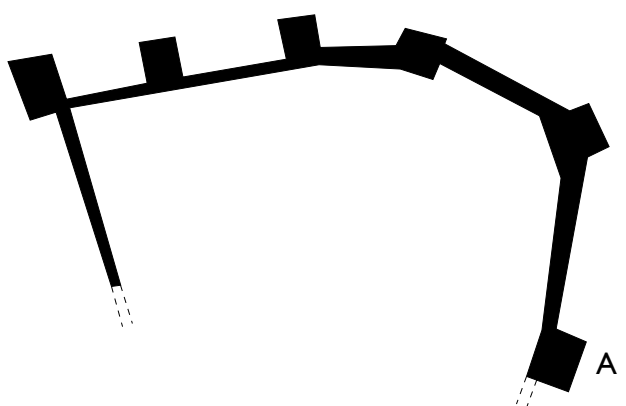

Reconstrucción hipotética de parte de las murallas islámicas
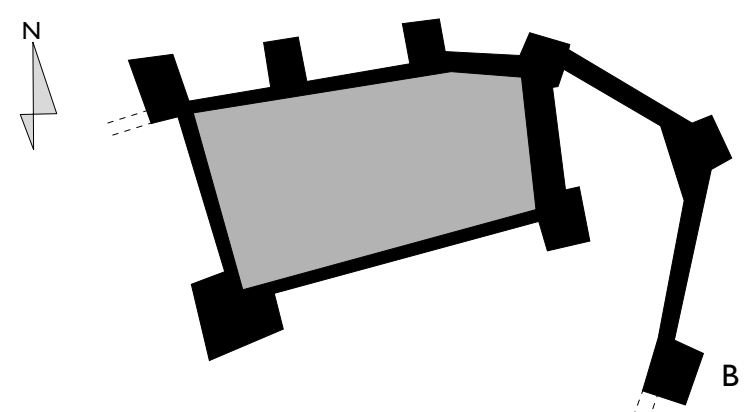

Reconstrucción hipotética del castillo calatravo

Fig. 20. La transformación de Hișn Sabiyuto (s. XIII) 


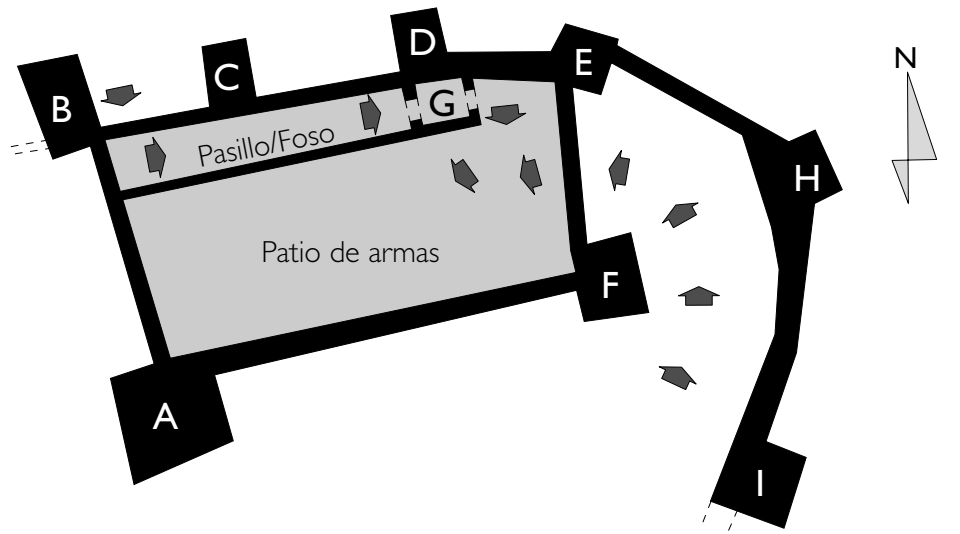

CASTILLO SEGÚN LA DOCUMENTACIÓN I533-I535
A:Torre del Homen
B:Torre de la Canal
E:Torre del Espolón
F:Torre de la Puerta
G:Torre del Patio
$\mathrm{H}$ :Torre del Baluarte
C-D-I: Sin determinar

Fig. 2 I. Castillo Calatravo de Sabiote

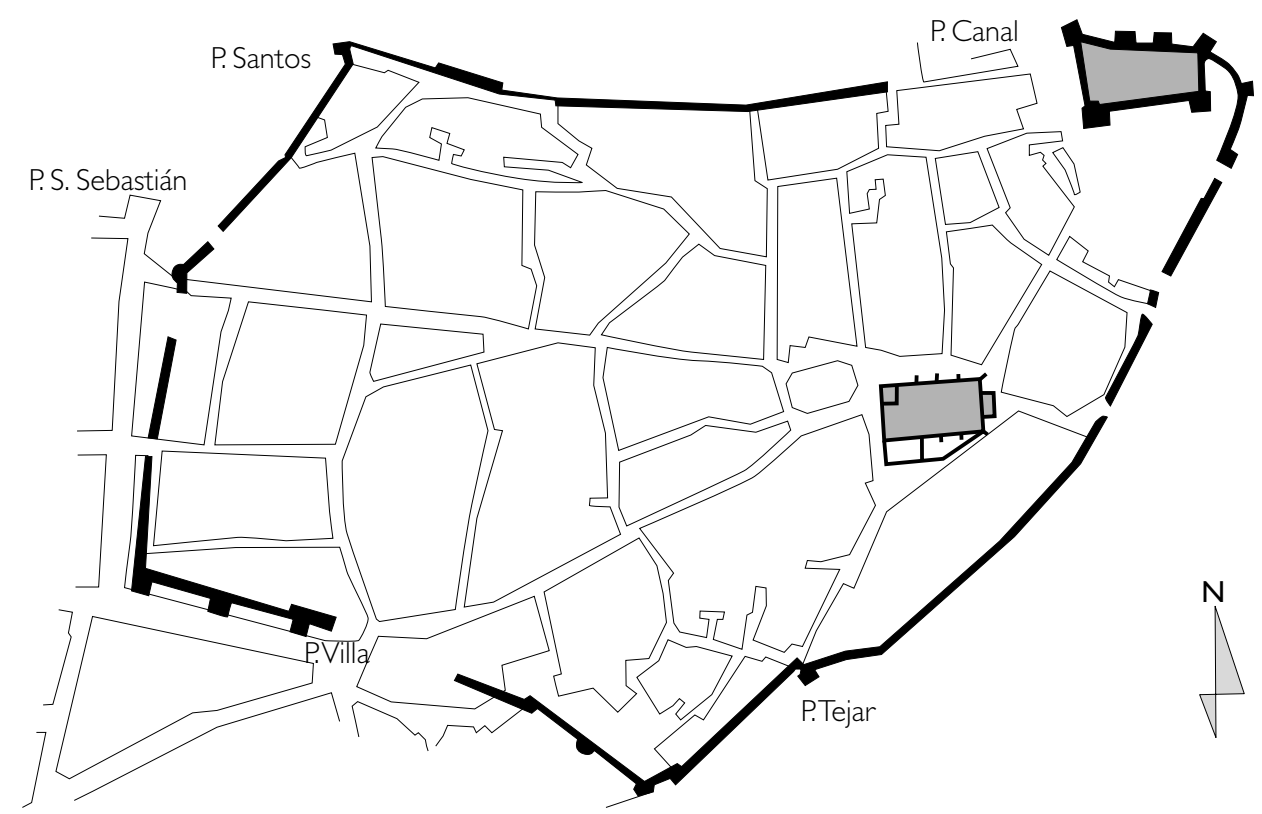

Fig. 22. Fortificaciones de la Villa de Sabiote 


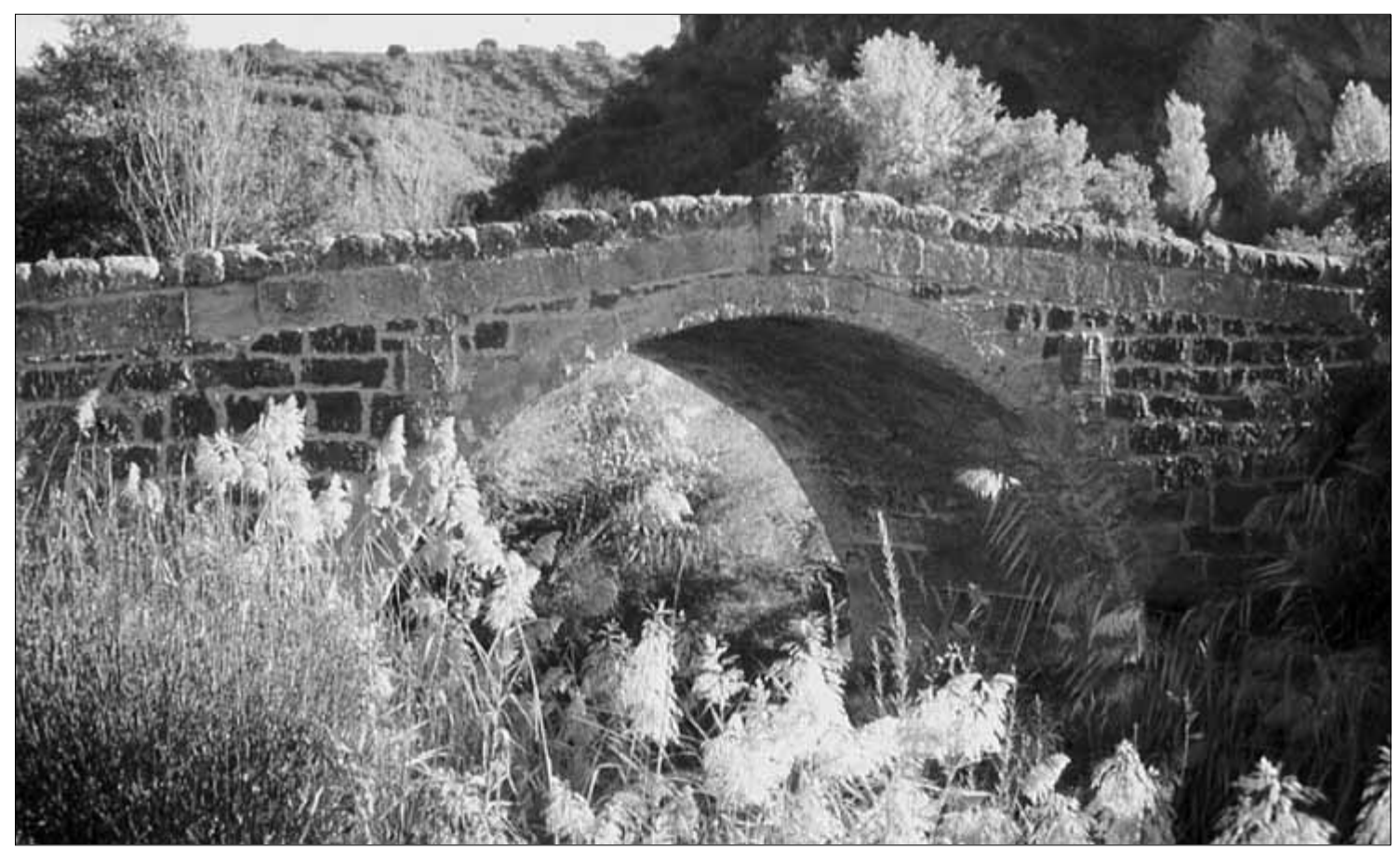

Lam. I. Puente de Martos

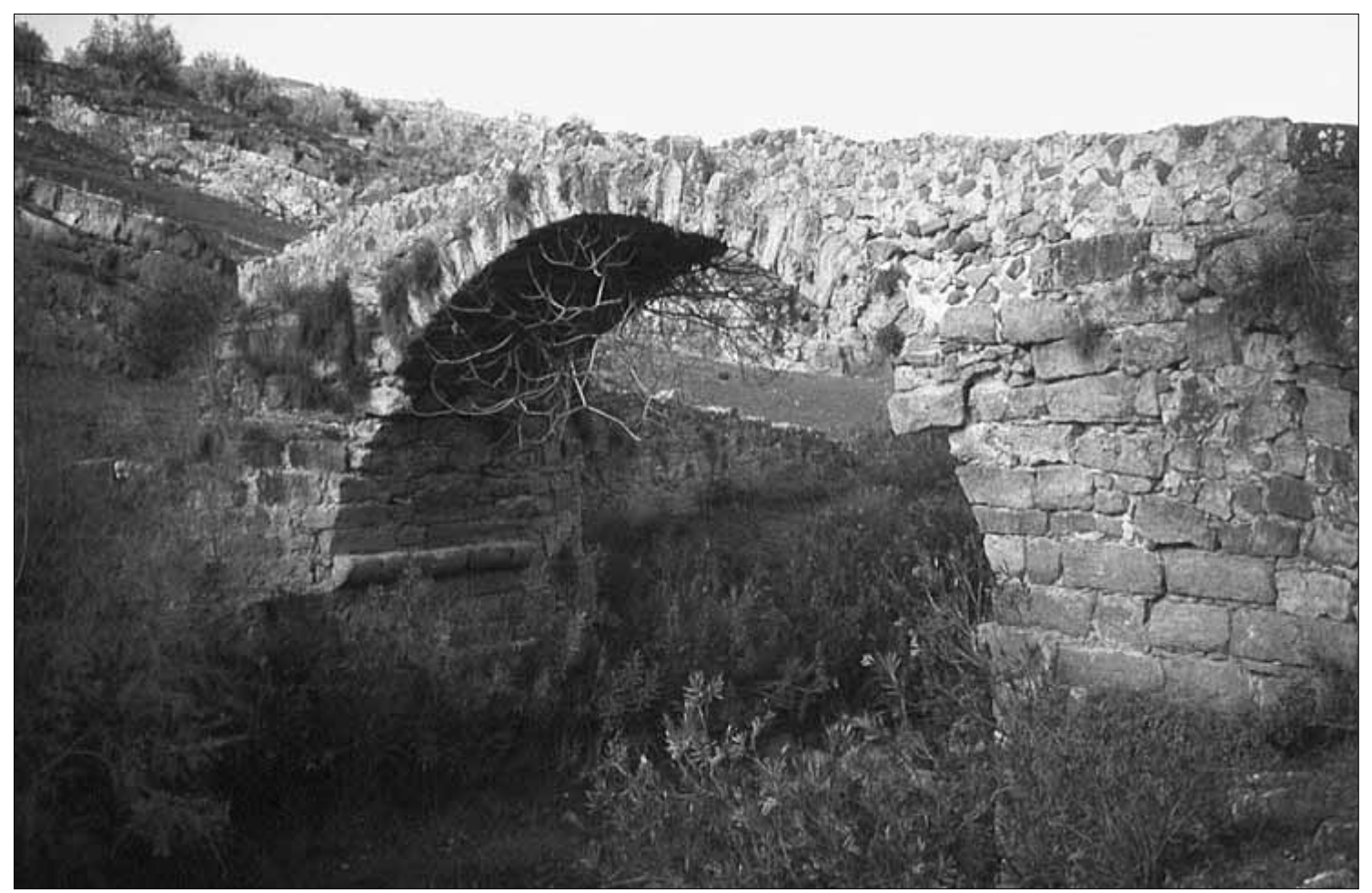

Lam. 2. Puente de Alcaudete 


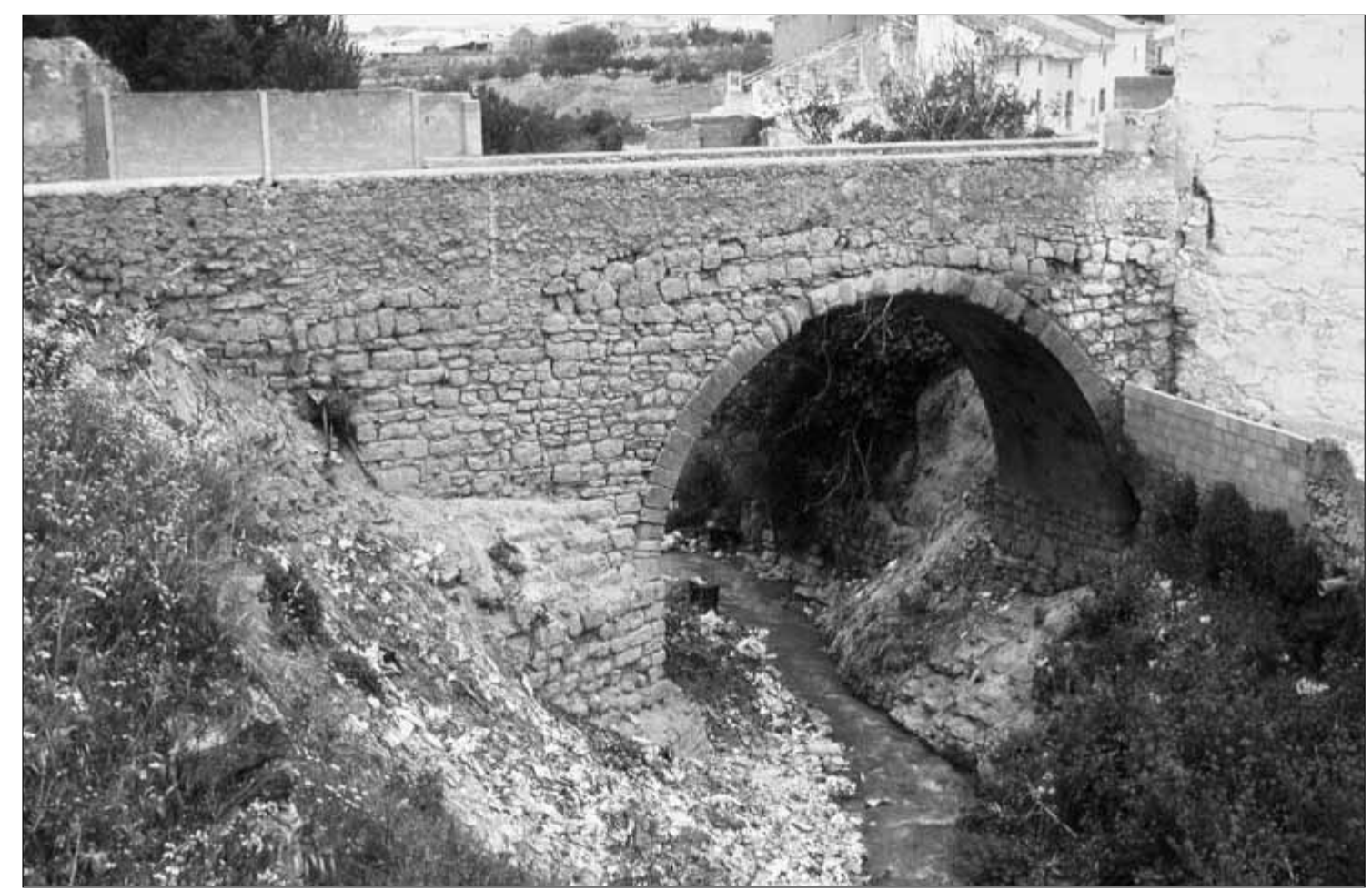

Lam. 3. Puente de Torredonjimeno

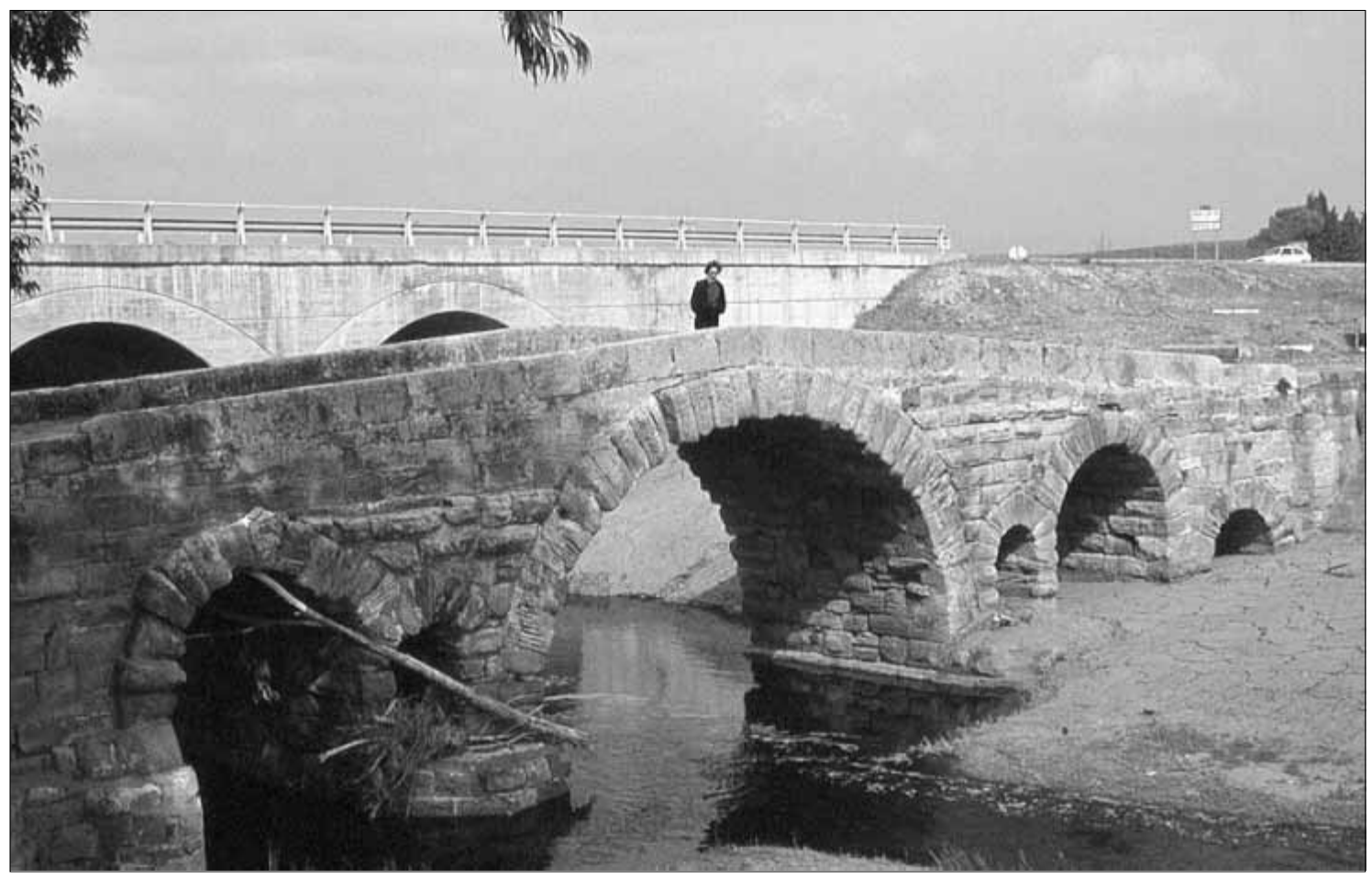

Lam. 4. Puente de Lopera 


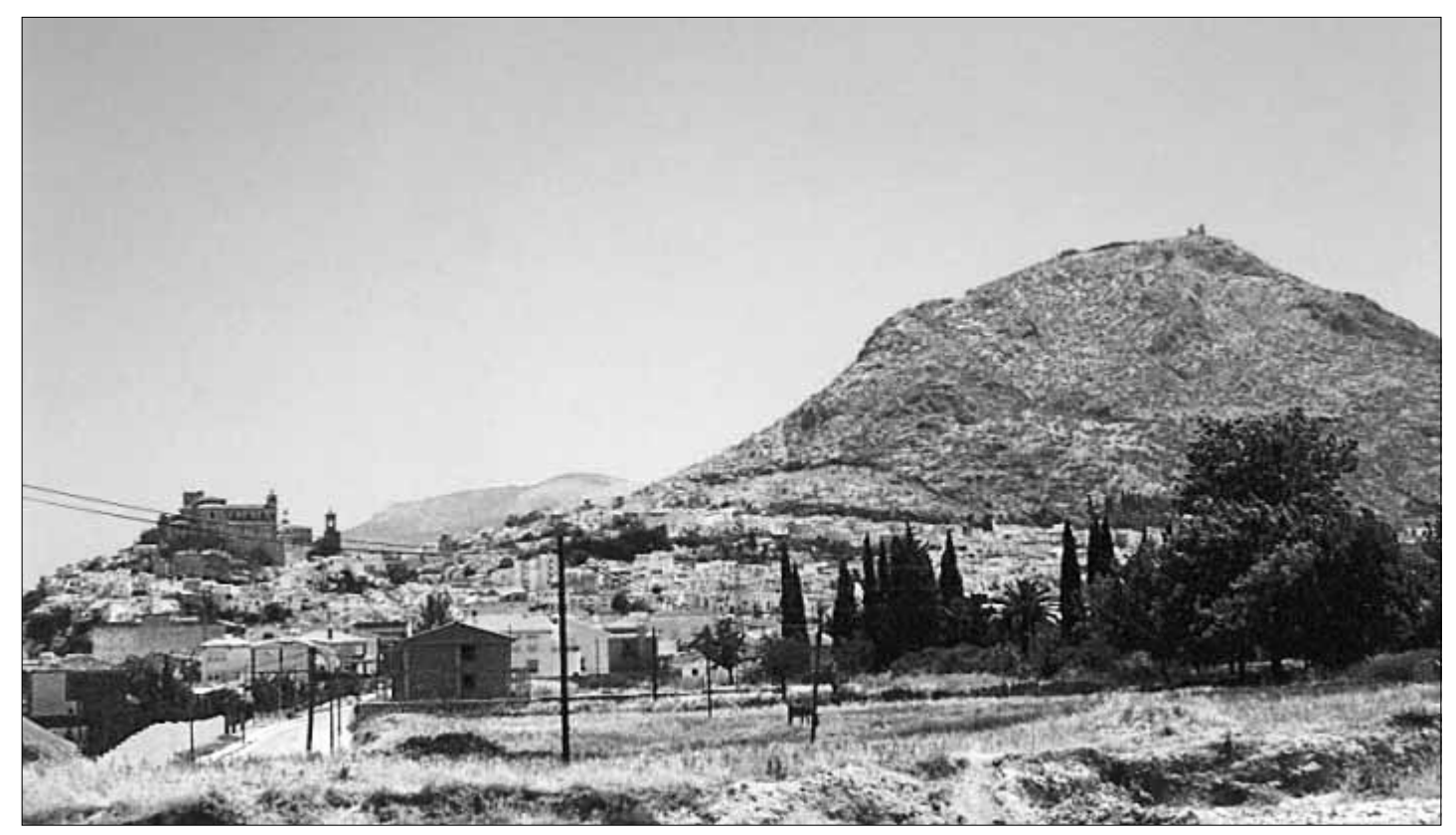

Lam. 5. Martos

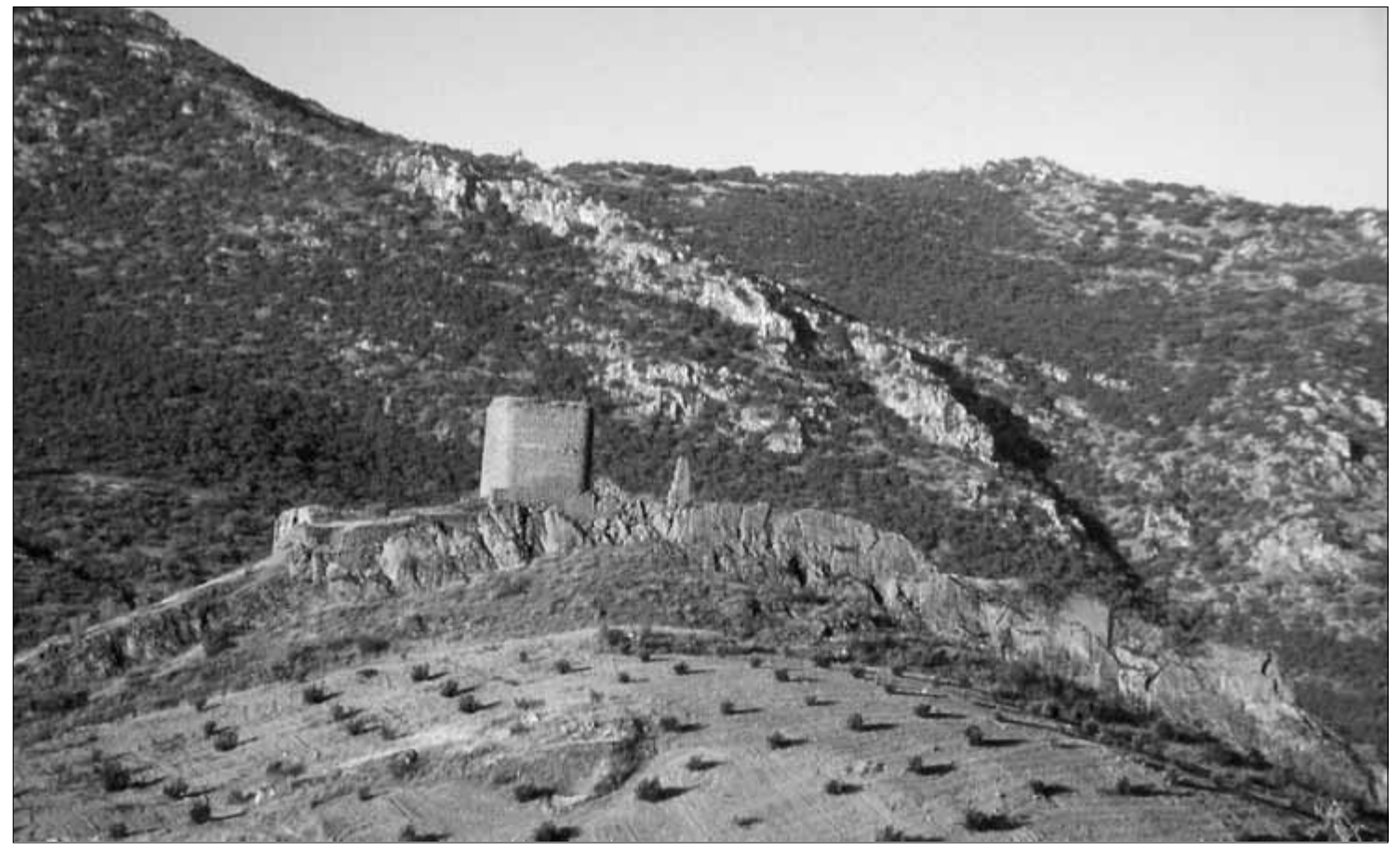

Lam. 6. Castillo de Víboras 


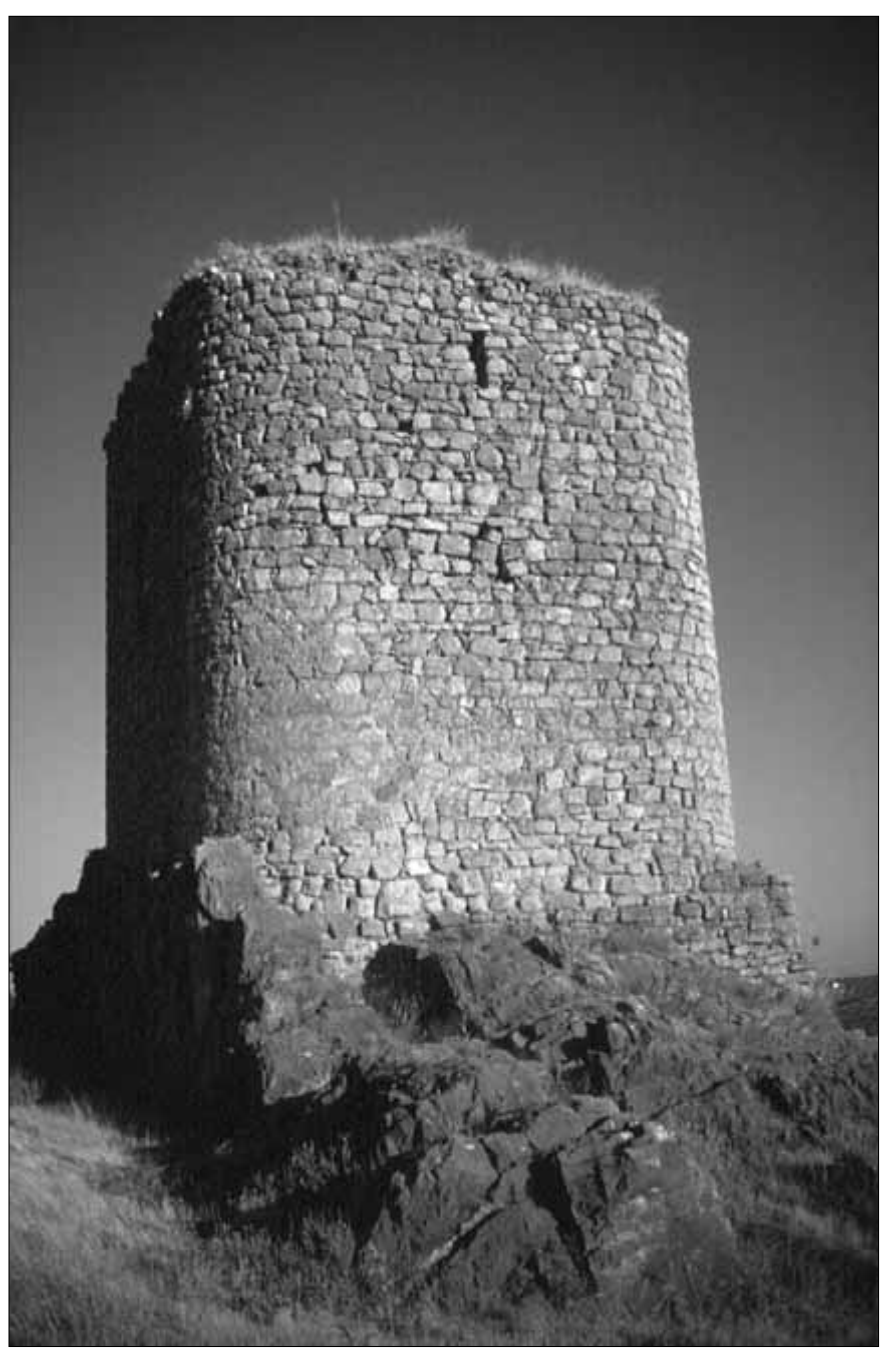

Lam. 7. Torre del Homenaje

del Castillo de Víboras

Lam. 8. Alcaudete

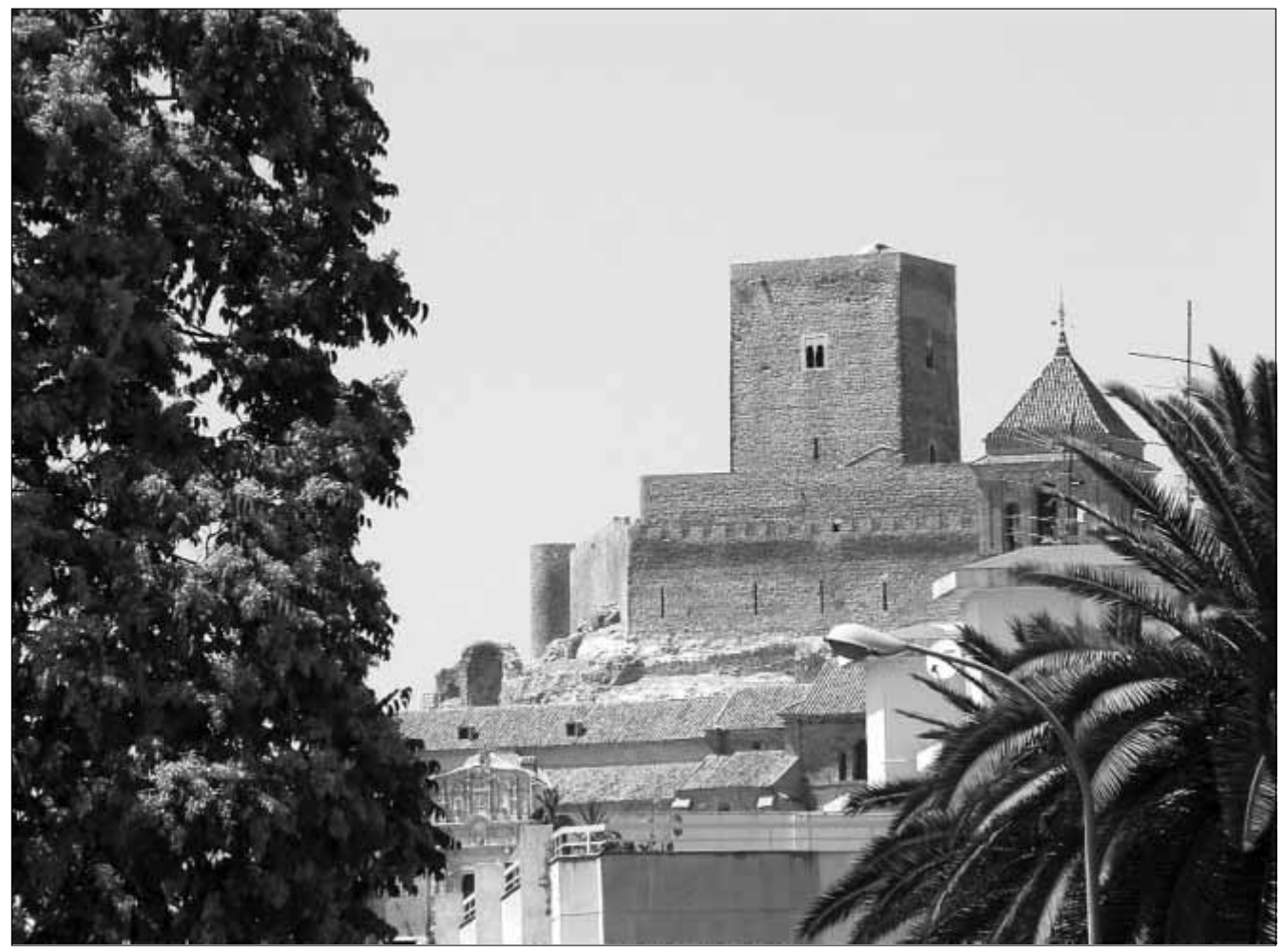




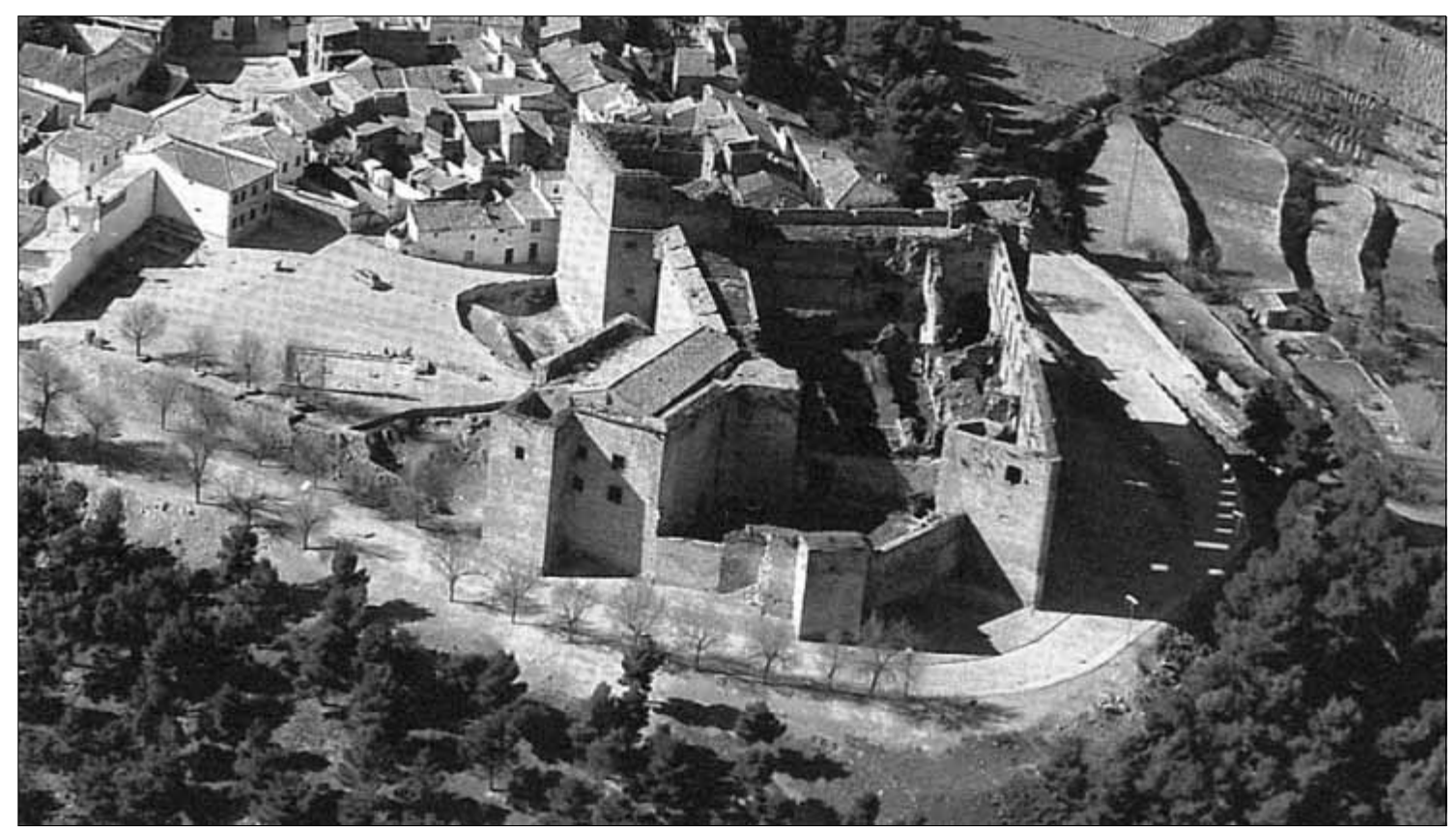

Lam. 9. Castillo de Sabiote

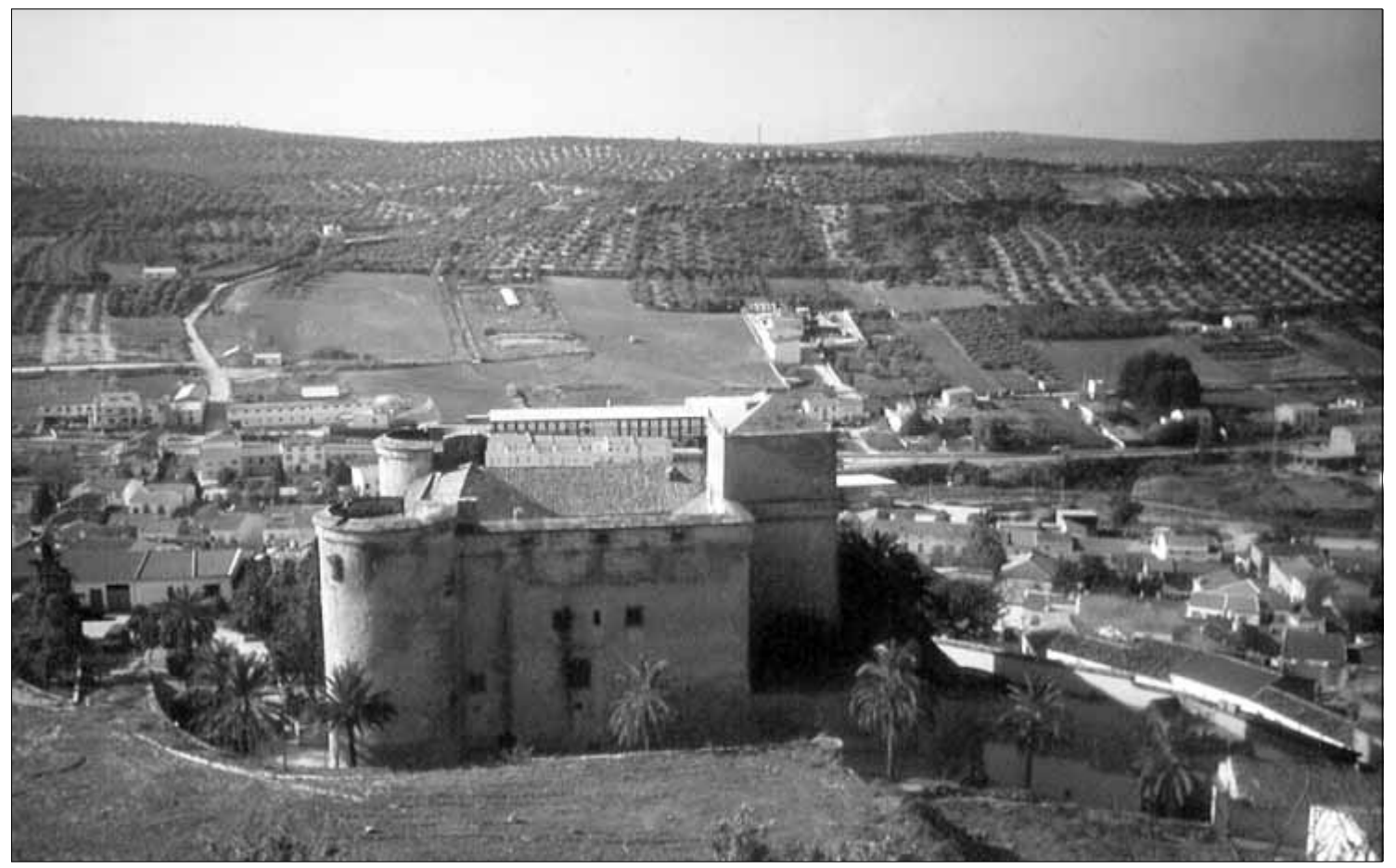

Lam. I0. Castillo de Canena 


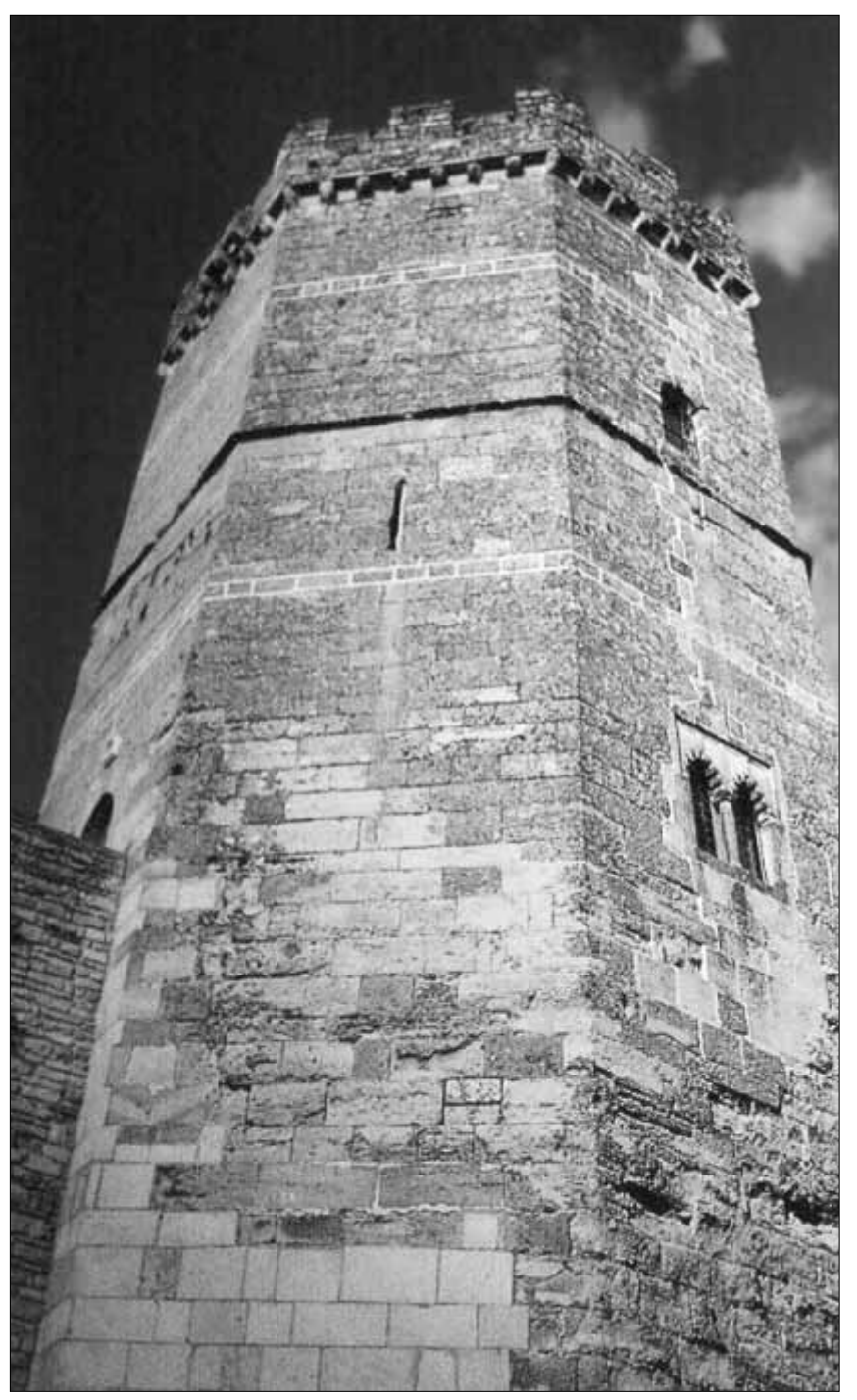

Lam. II. Torre del

Homenaje del Castillo

de Porcuna

Lam. I2. Castillo de Torredonjimeno

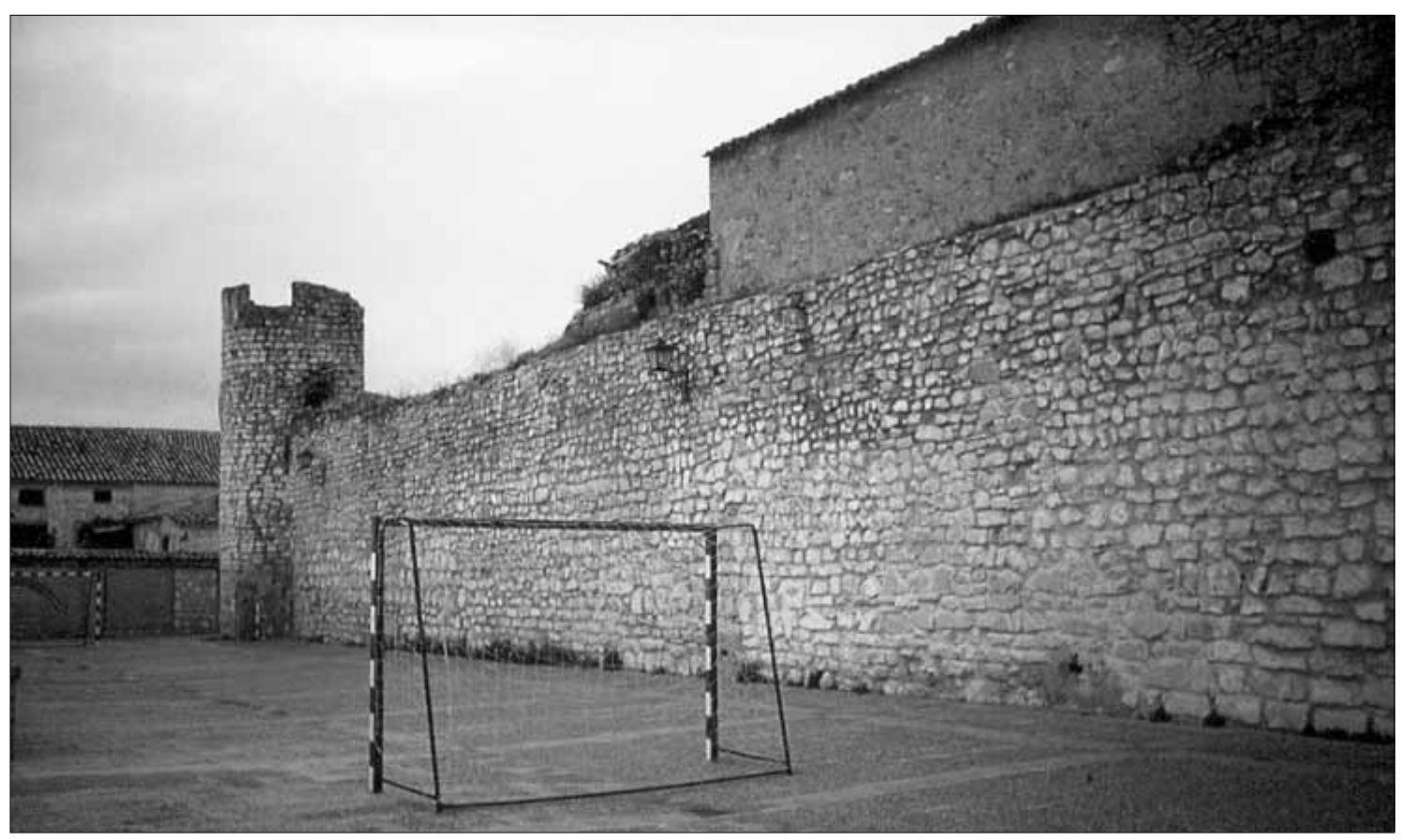




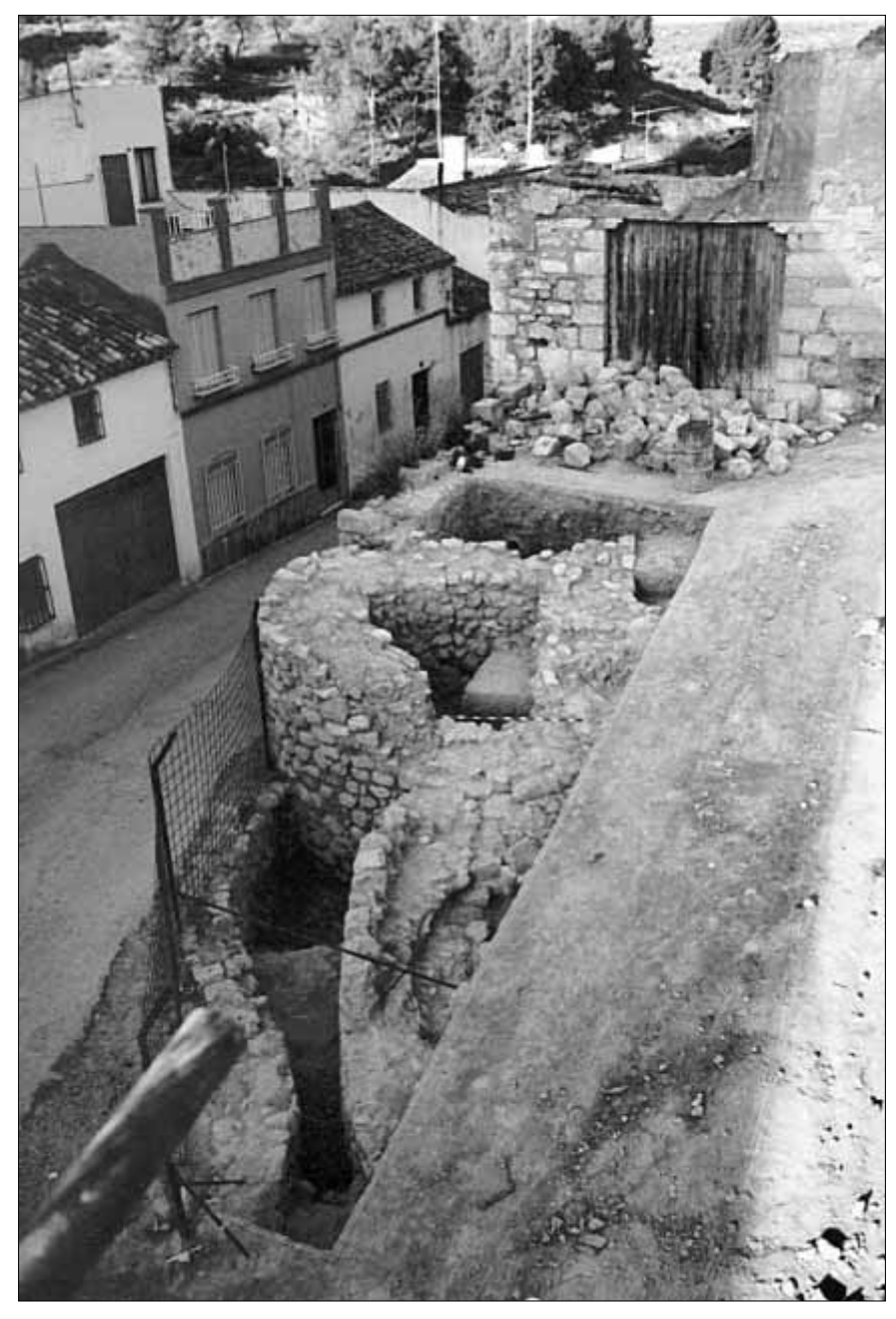

Lam. I3. Castillo de Torredonjimeno

Lam. 13. Castillo de Torredonimeno

\section{.}

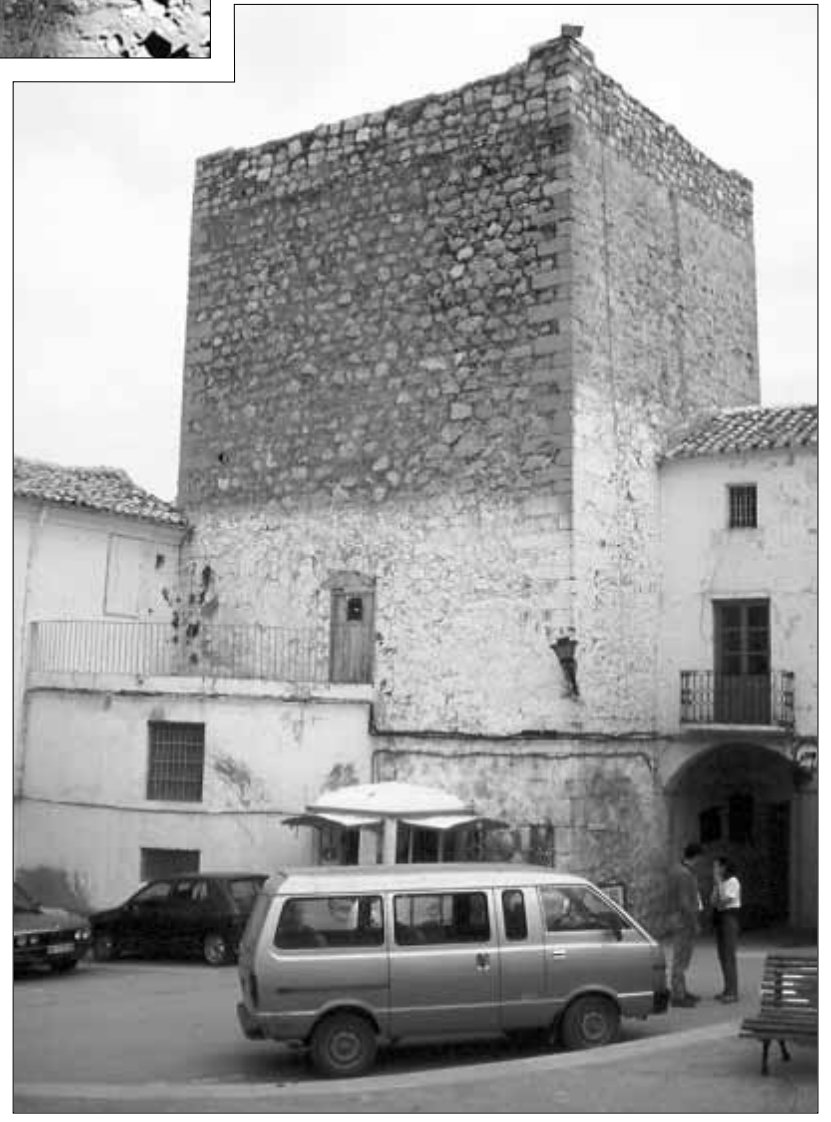

Lam. I4. Torre del Homenaje del Castillo de Jimena 


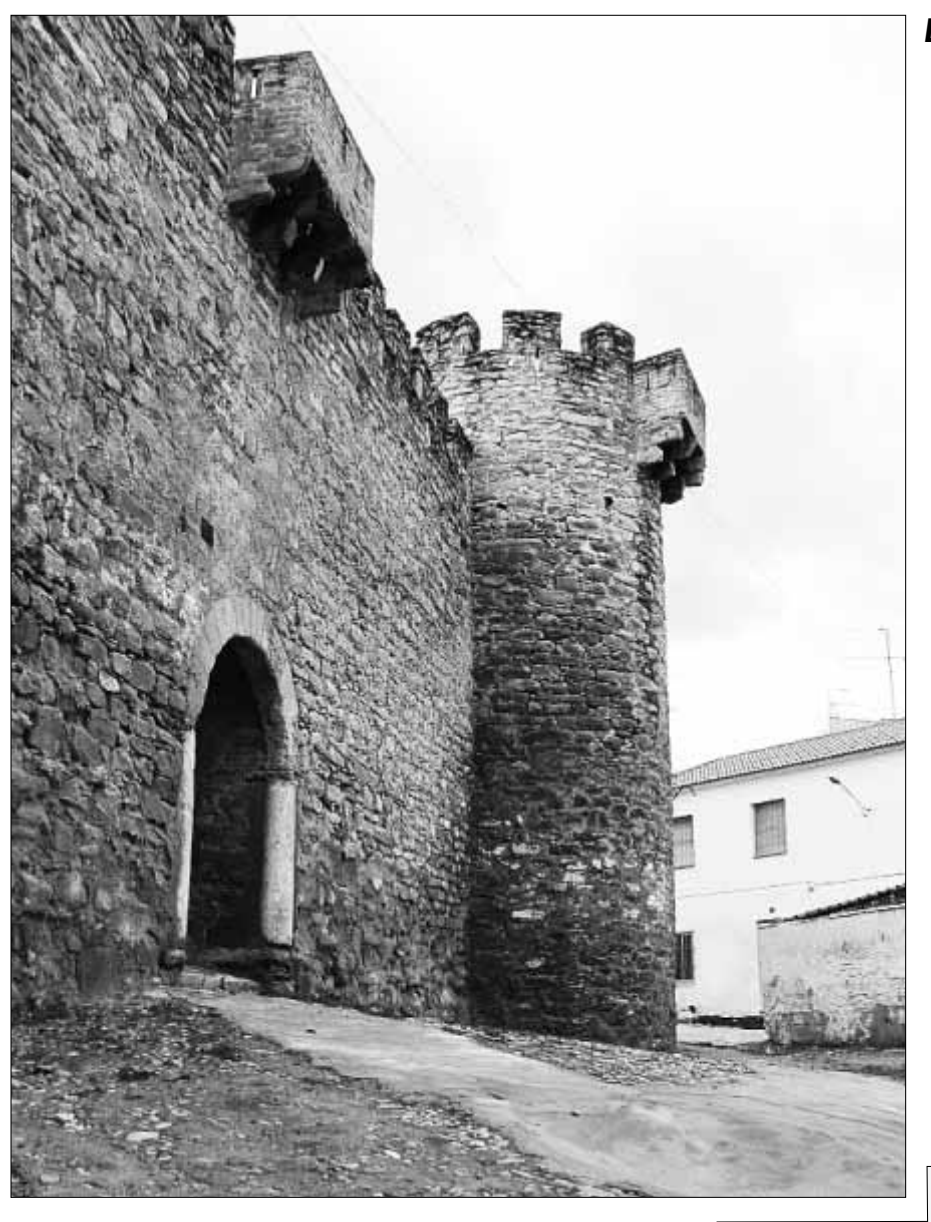

Lam. I5. Castillo de Lopera
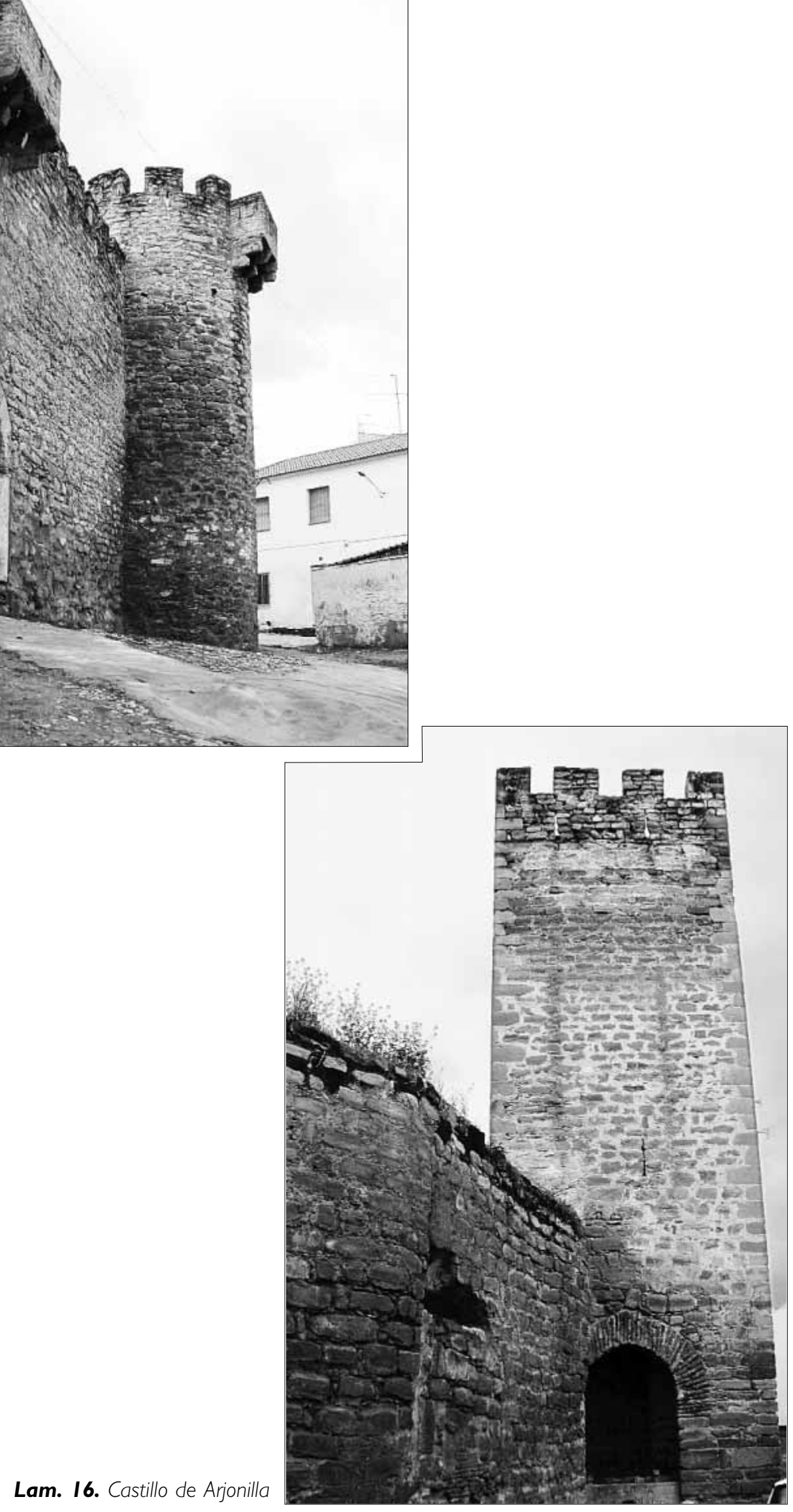
Lam. I 7. Castillo de

Higuera de Calatrava

Lam. I8. Castillo

de Torrevieja

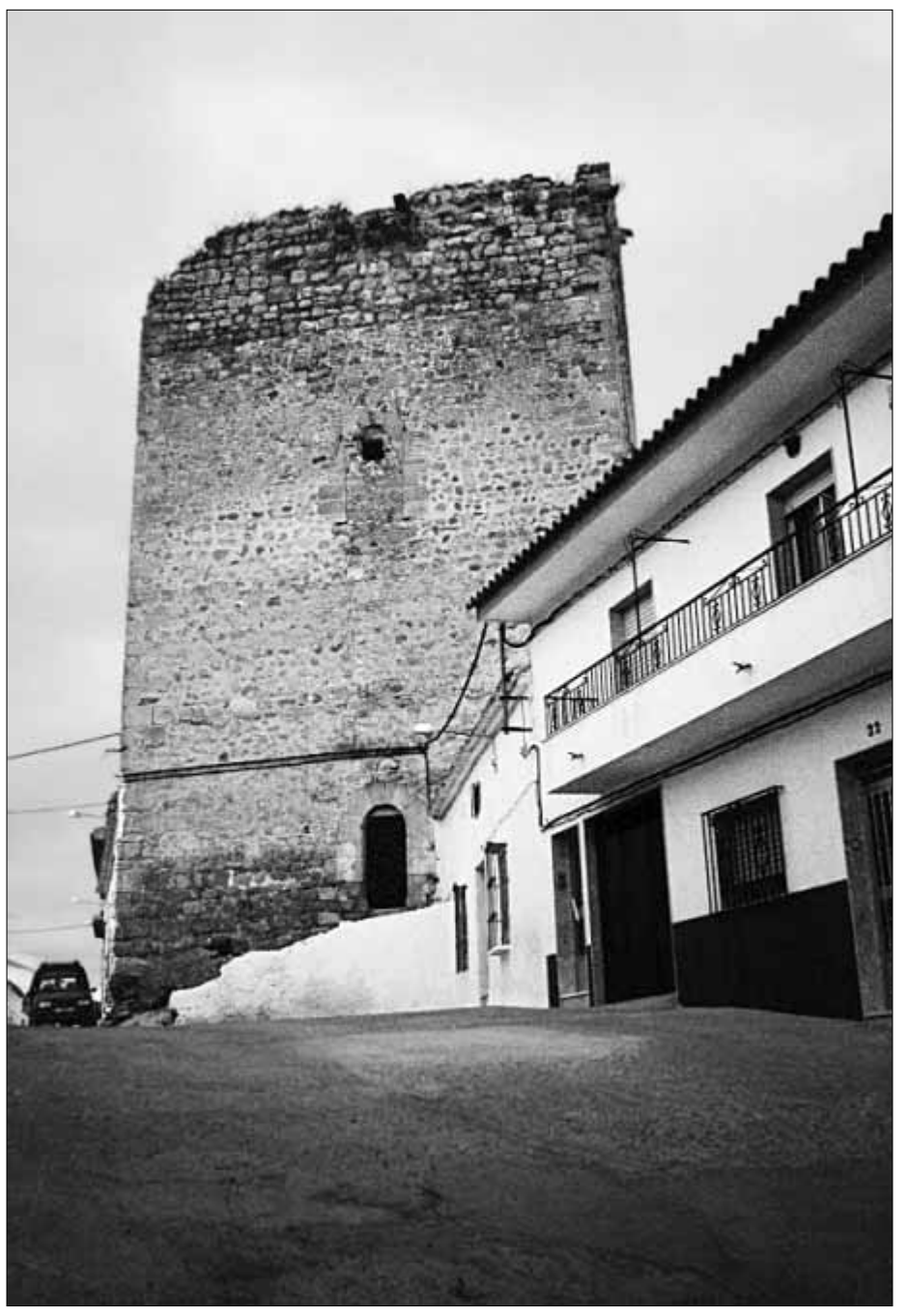

(Fuensanta)

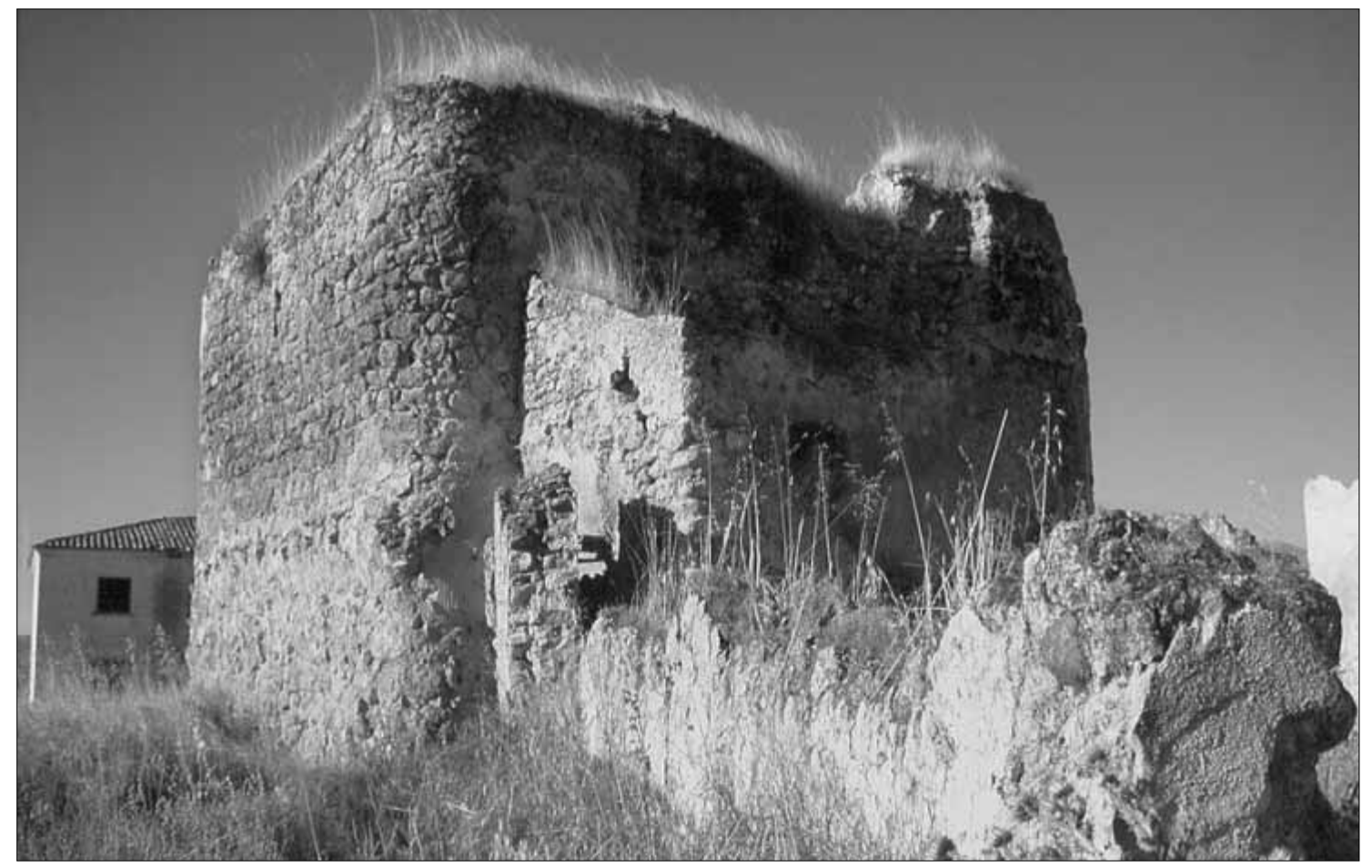




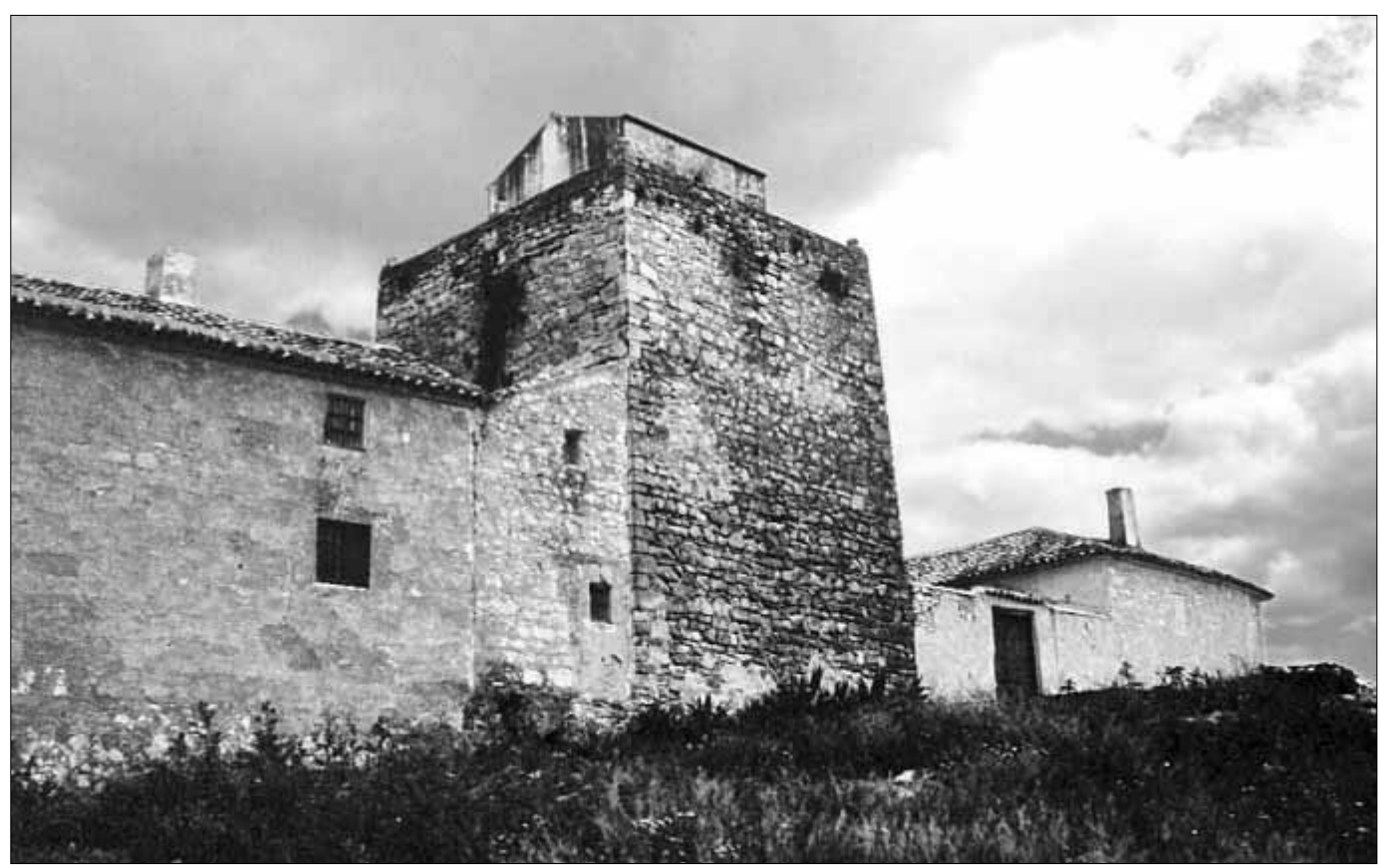

Lam. 19. Castillo de Torre Alcázar (Torredonjimeno)

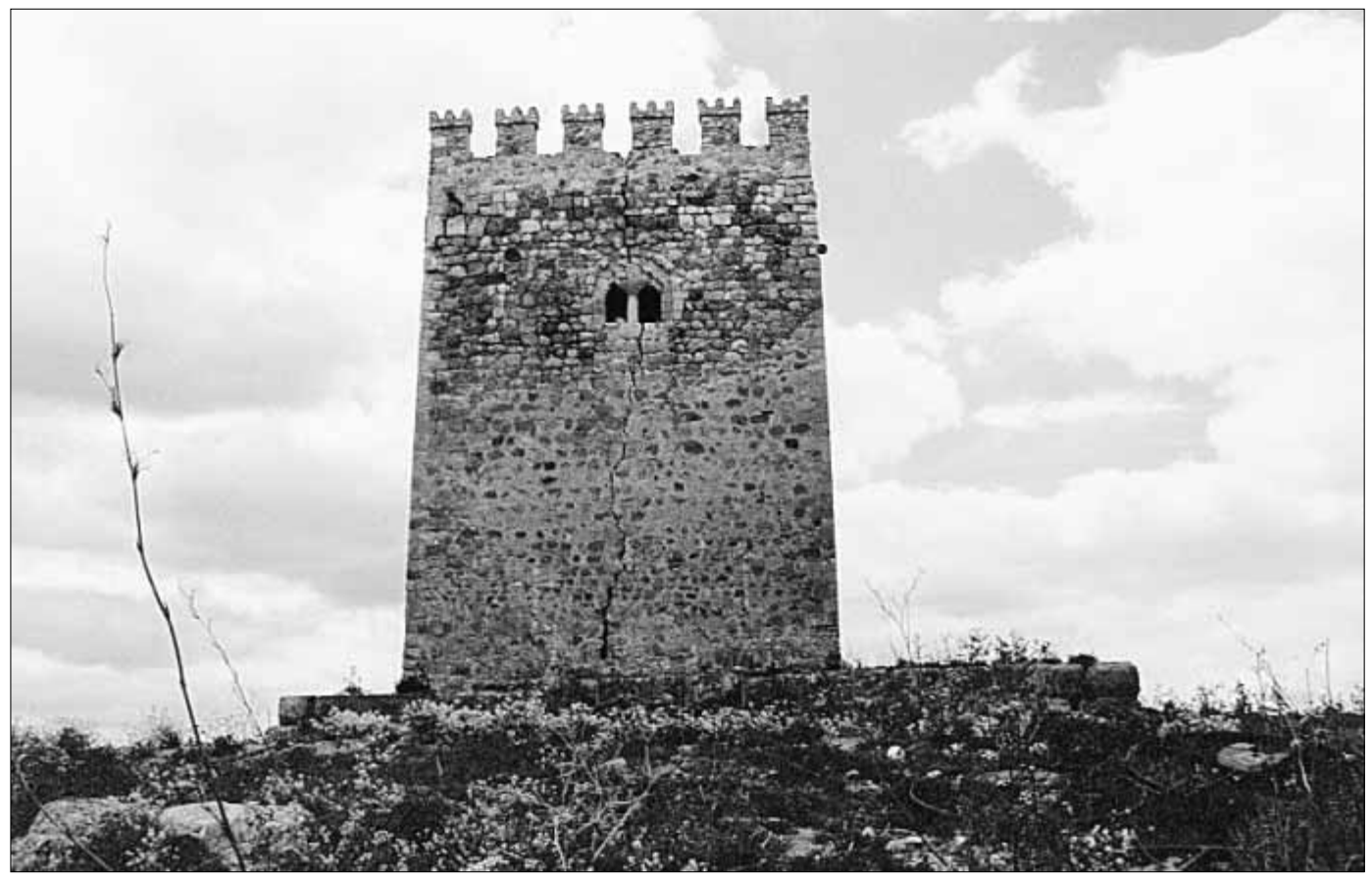

Lam. 20. Torre de Fuencubierta (Torredonjimeno) 
Lam. 2 I. Torre de Valcotón

(Castillo de Locubín)

Lam. 22. Torre del

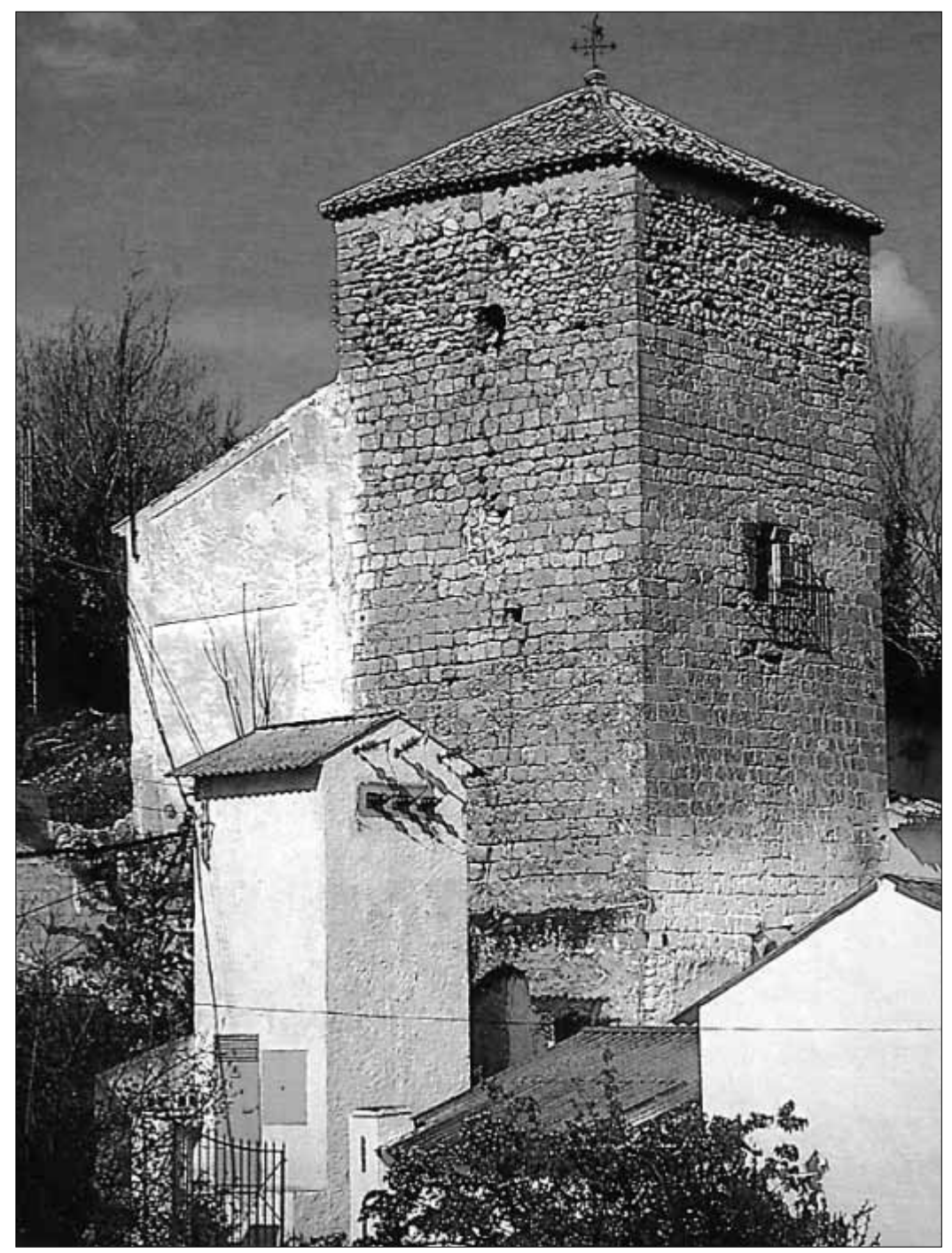

Algarrobo (Fuensanta)

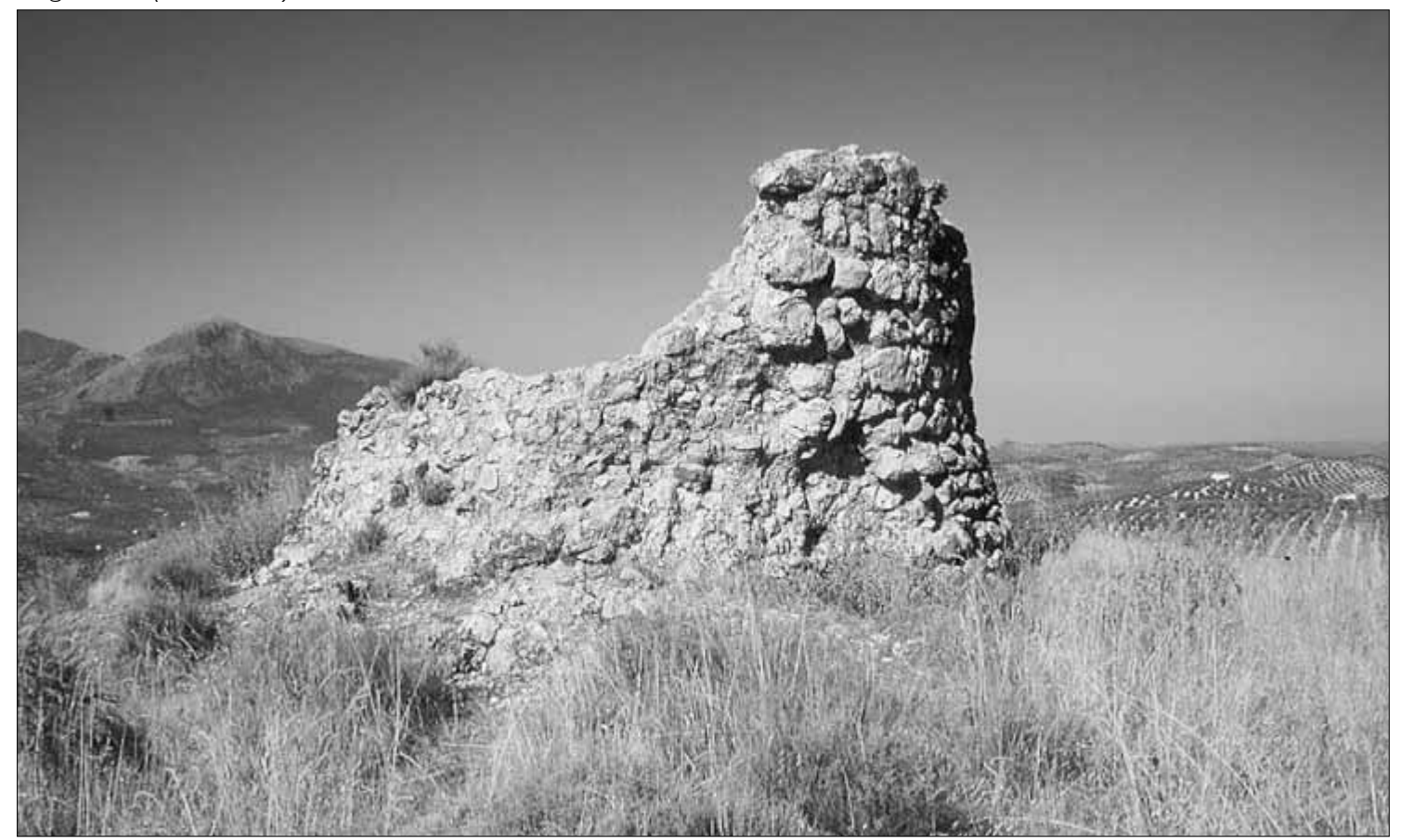




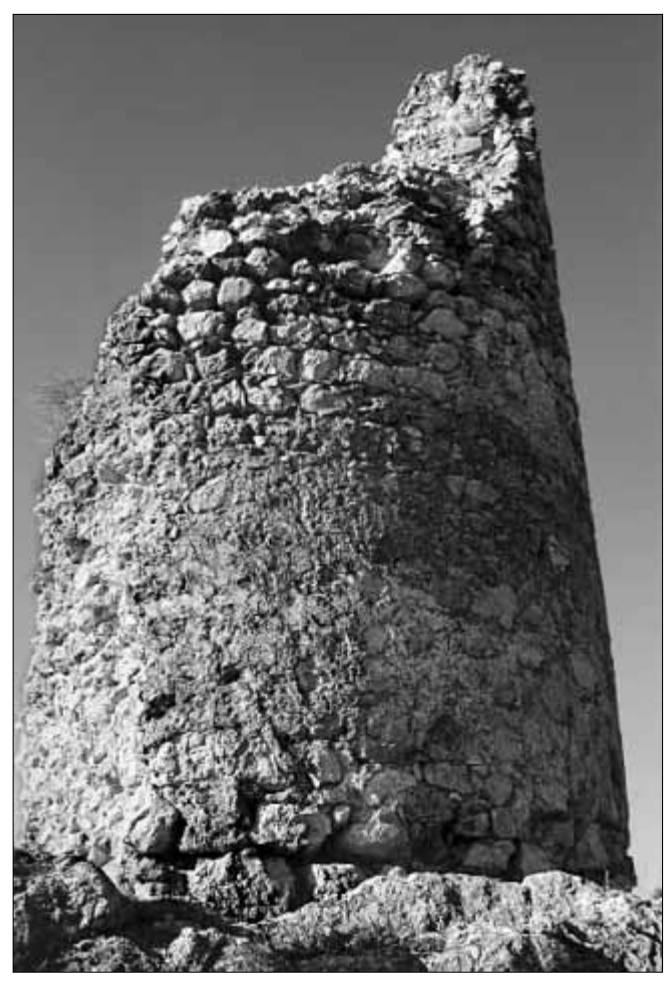

Lam. 23. Torre del Moro (Alcaudete)

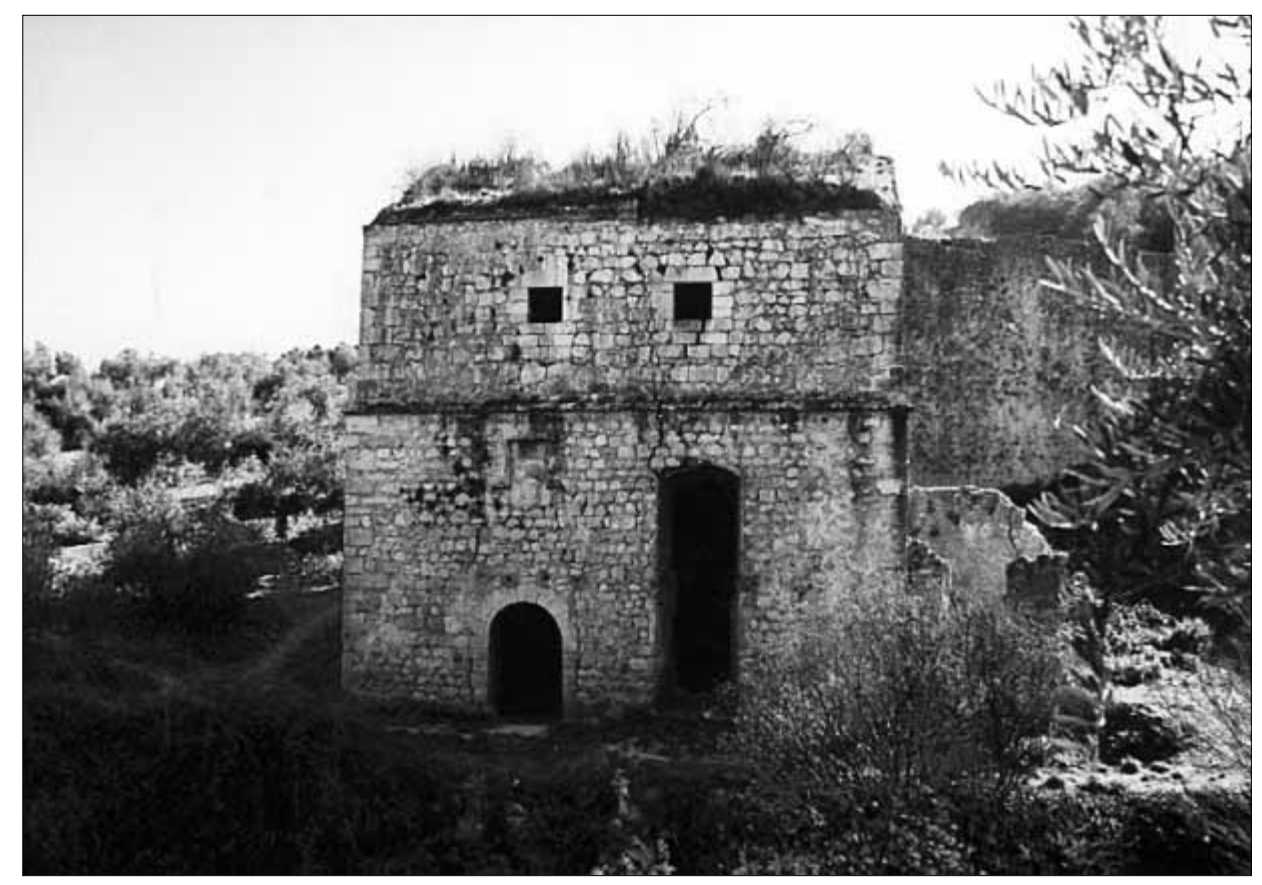

Lam. 24. Molino Fortificado del Cubo (Torredonjimeno) 
Lam. 25. Molino Fortificado

del Cubo (Torredonjimeno)

Lam. 26. Estructuras

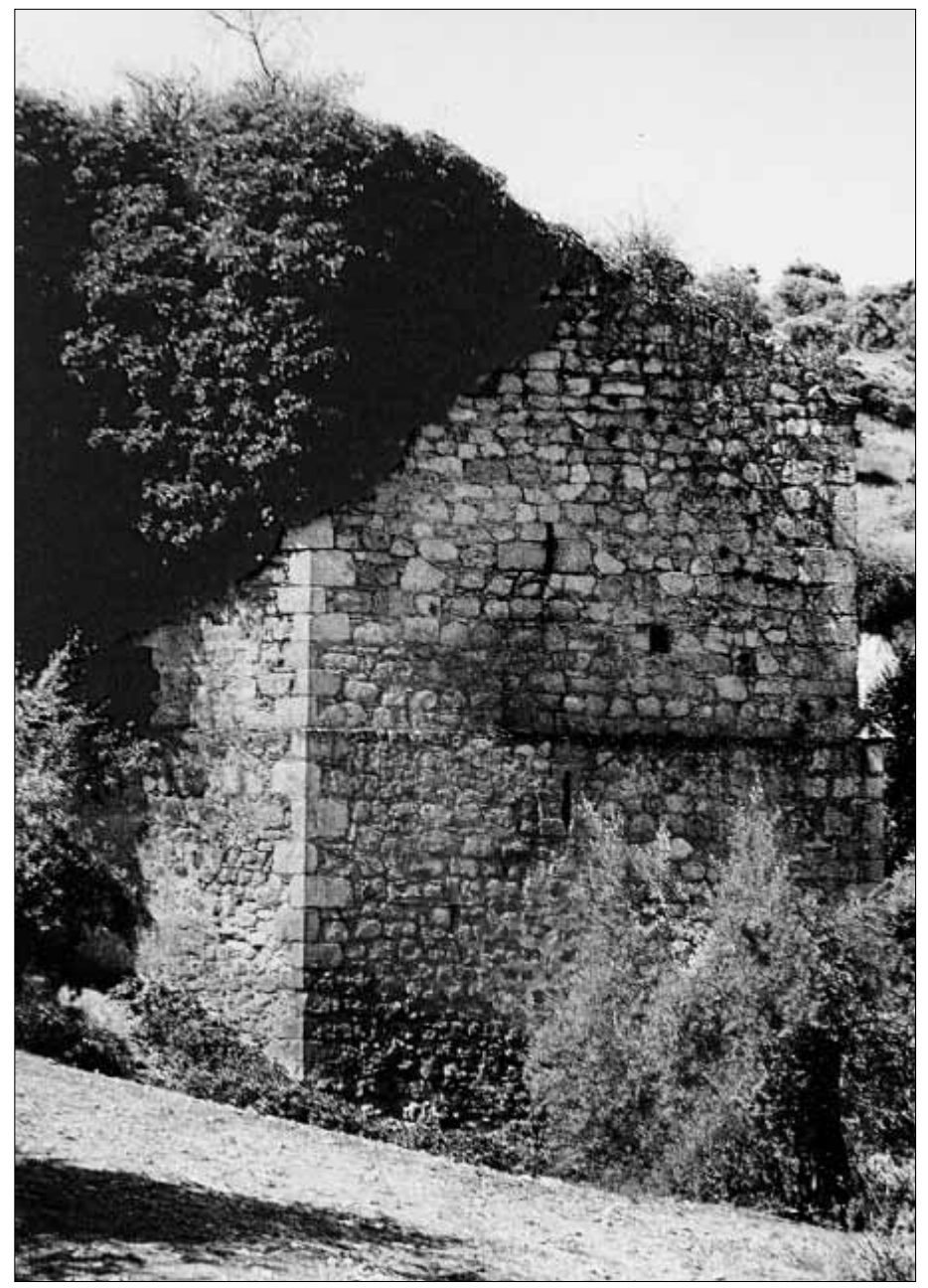

defensivas de Alcaudete

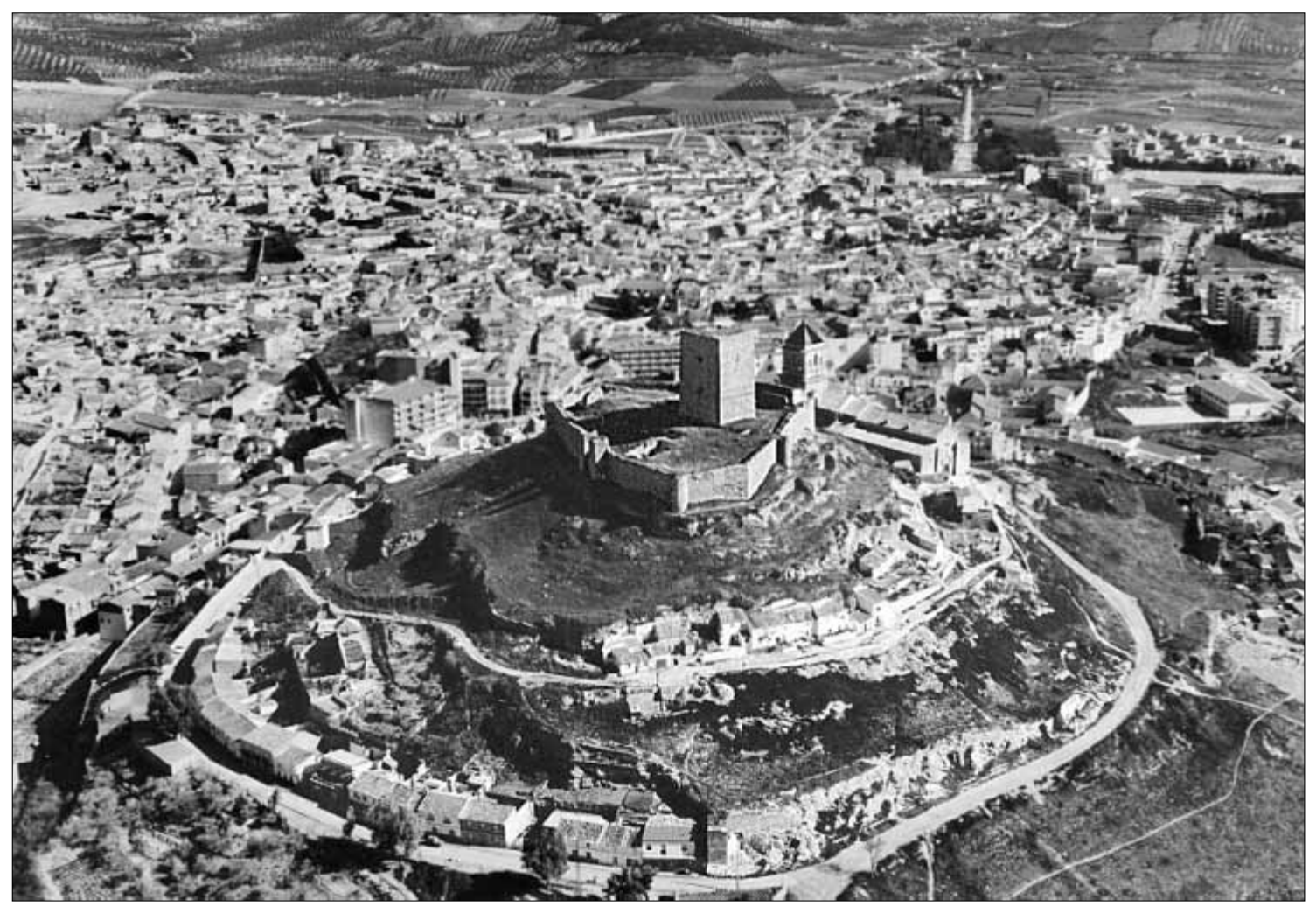




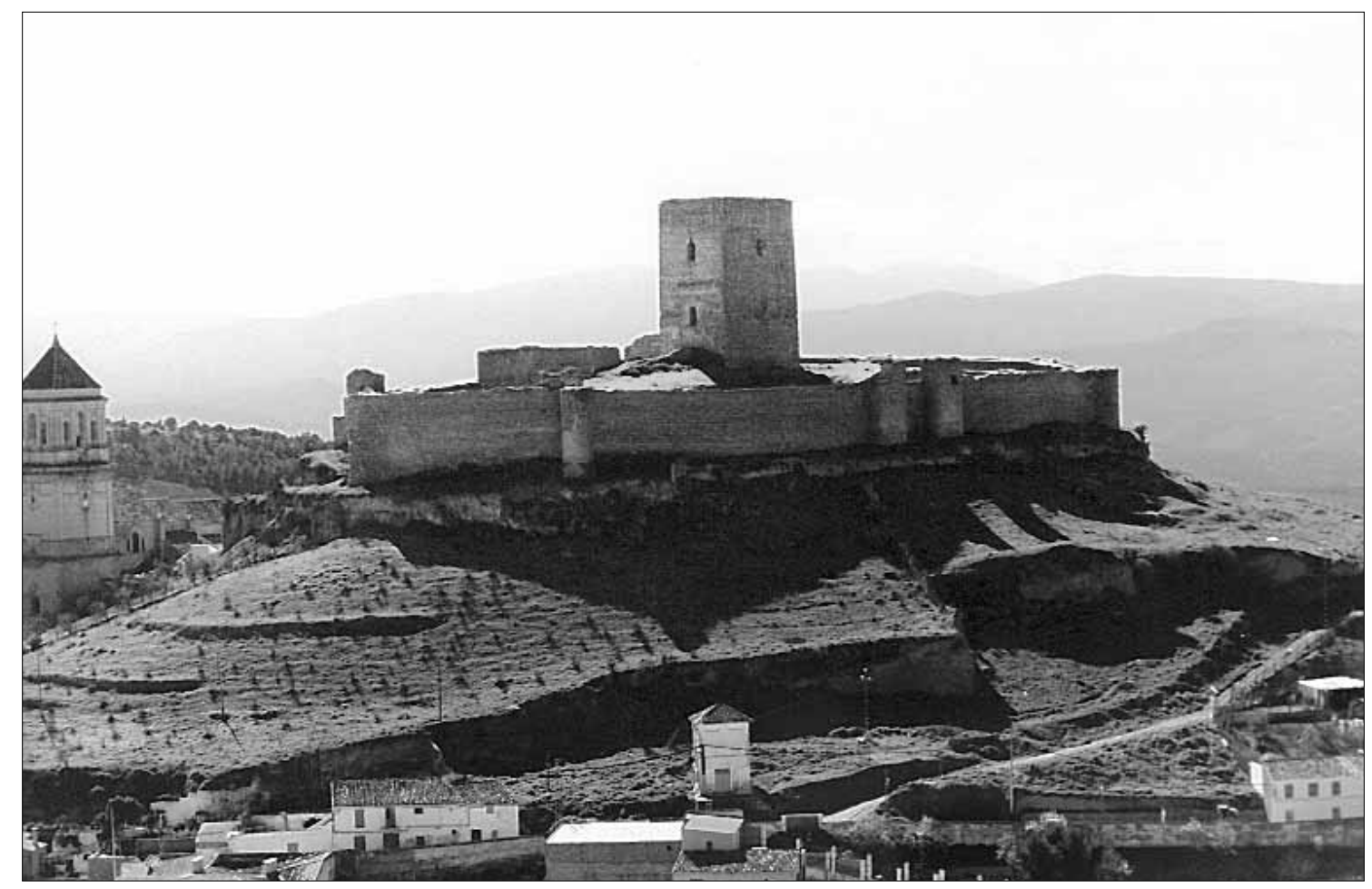

Lam. 27. Castillo de Alcaudete

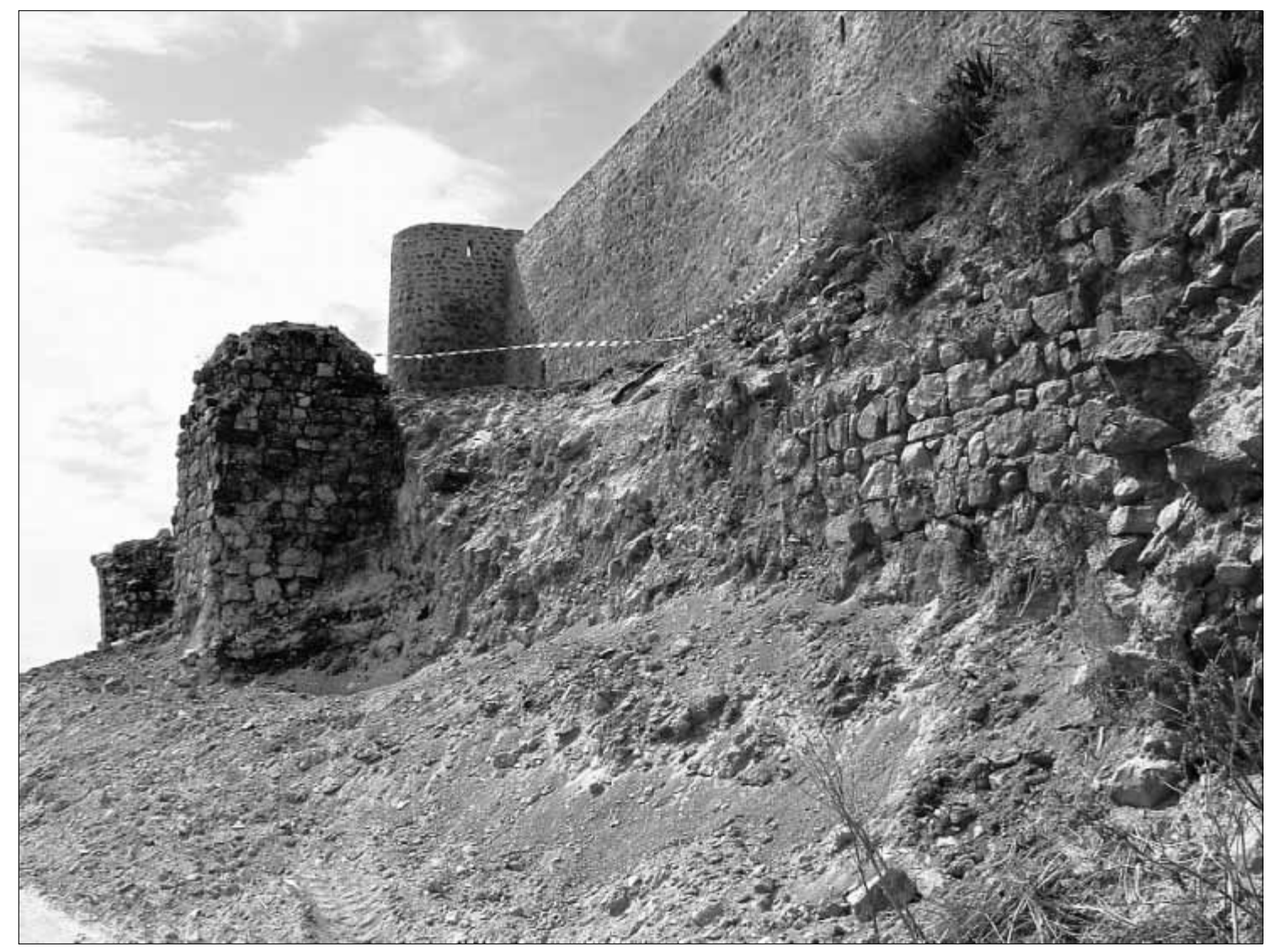

Lam. 28. Muralla de la liza del Castillo de Alcaudete 


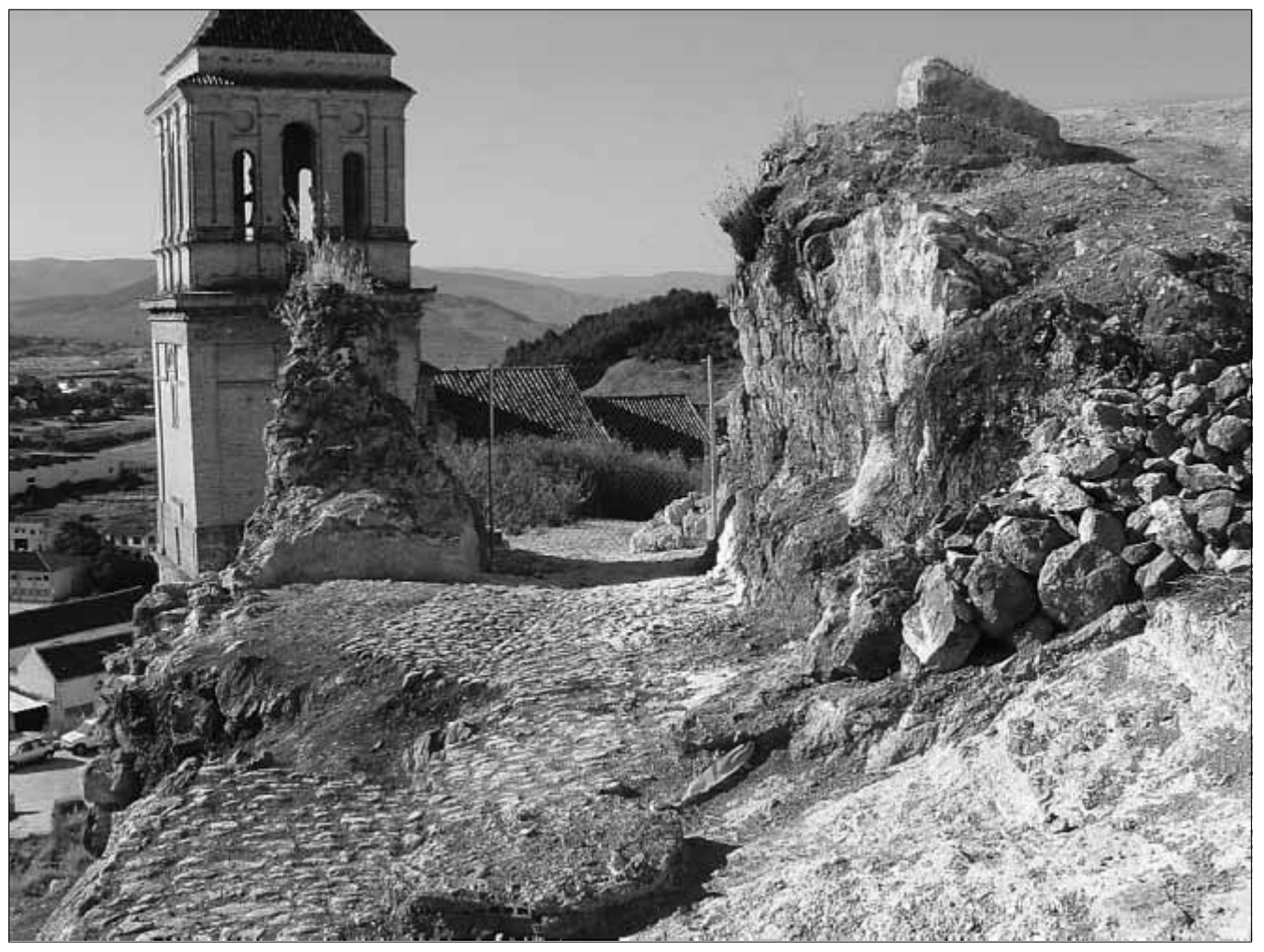

Lam. 29. Puerta de acceso a

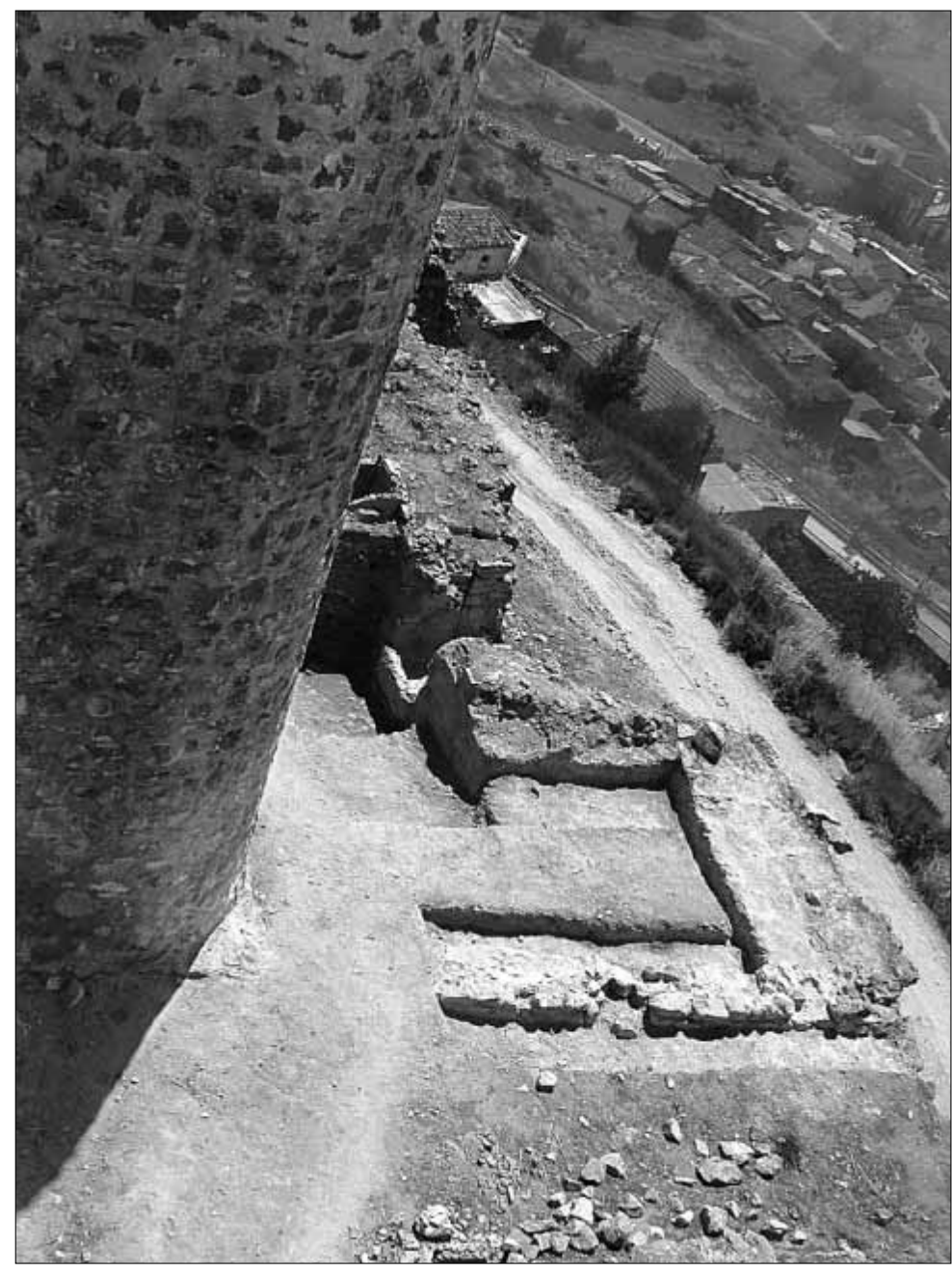

la liza del Castillo de Alcaudete

Lam. 30. Liza del Castillo

de Alcaudete 


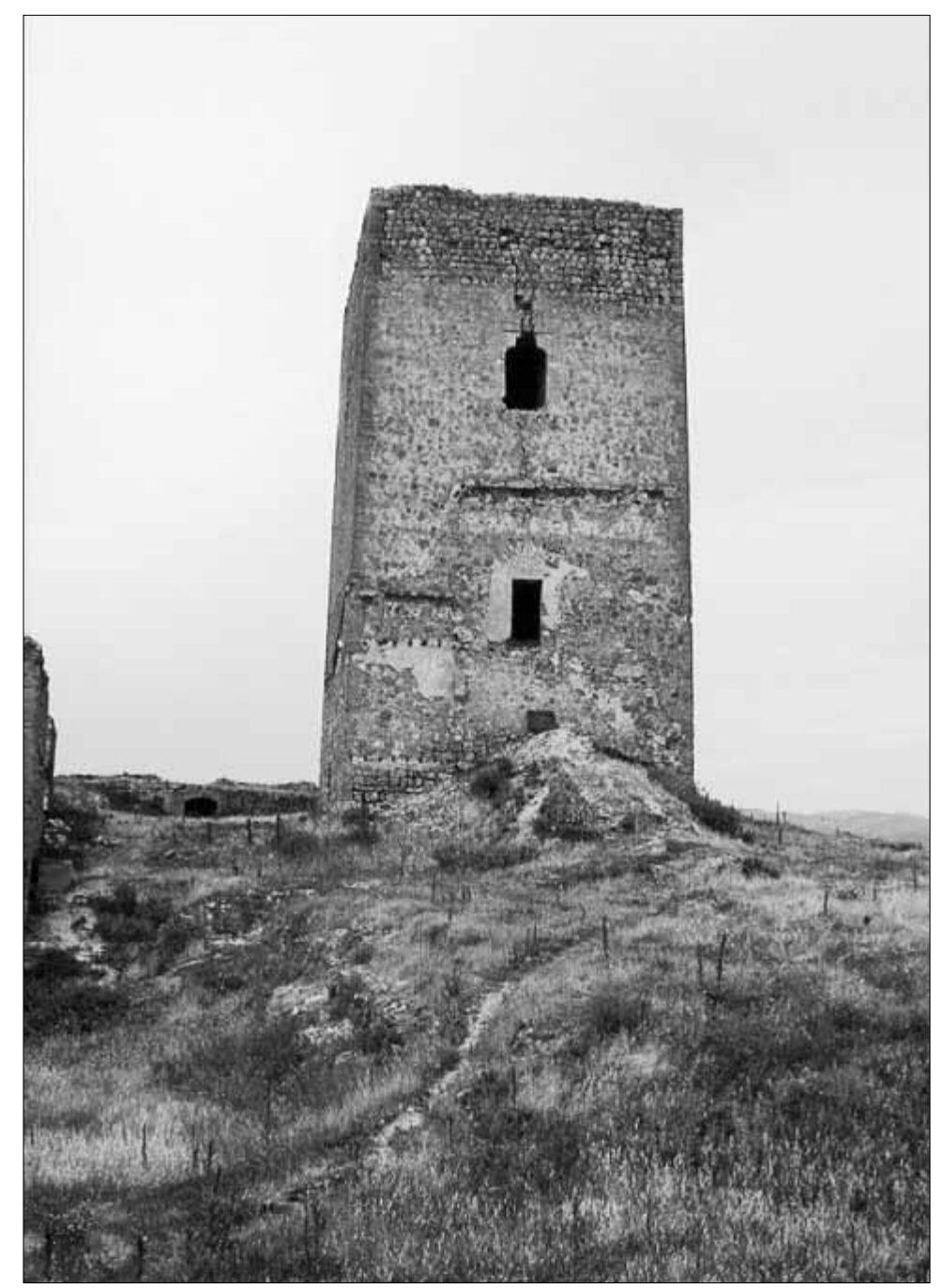

Lam. 3I. Torre del Homenaje

del Castillo de Alcaudete

Lam. 32. Fortificación de la Villa de Martos

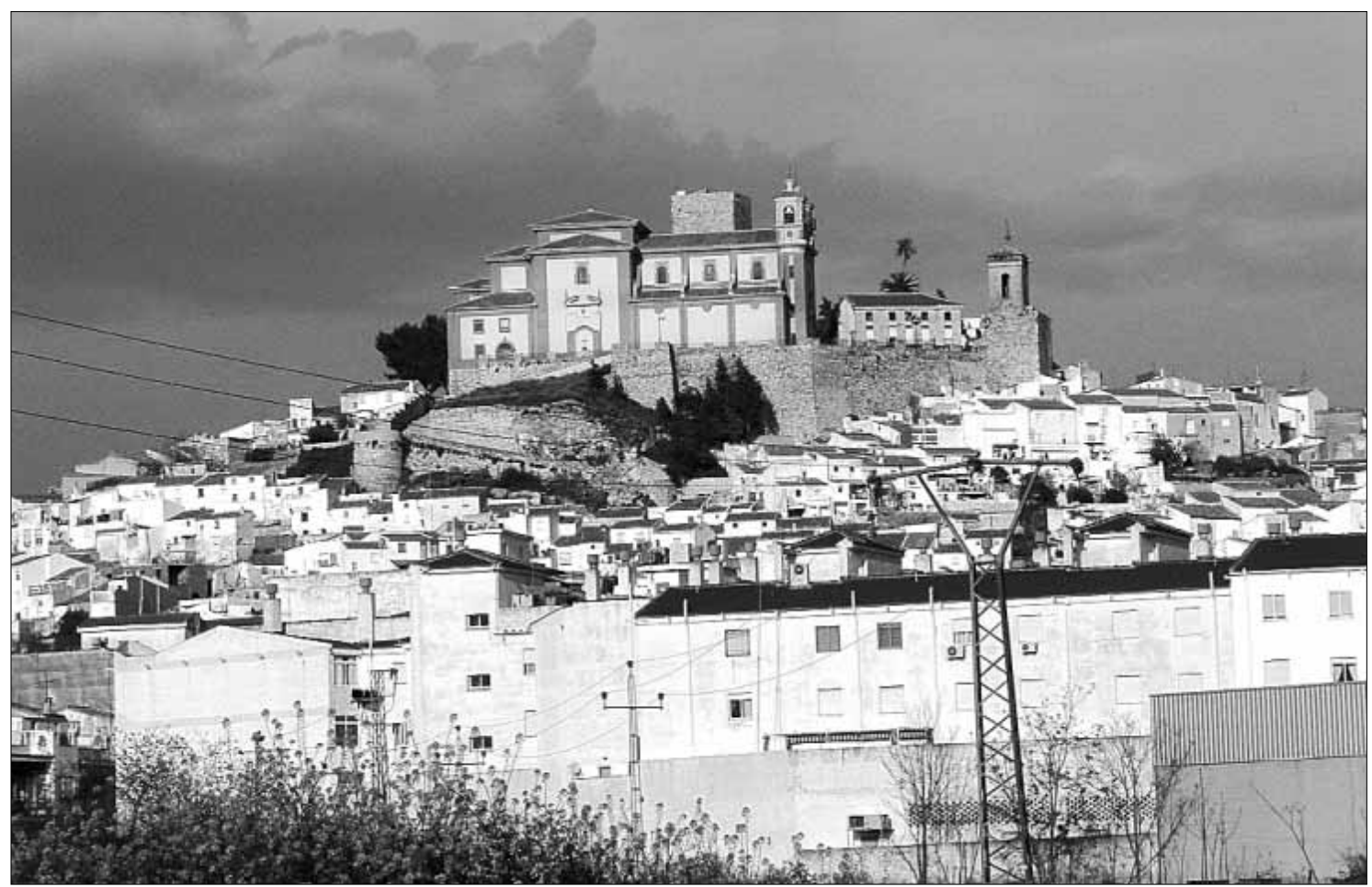




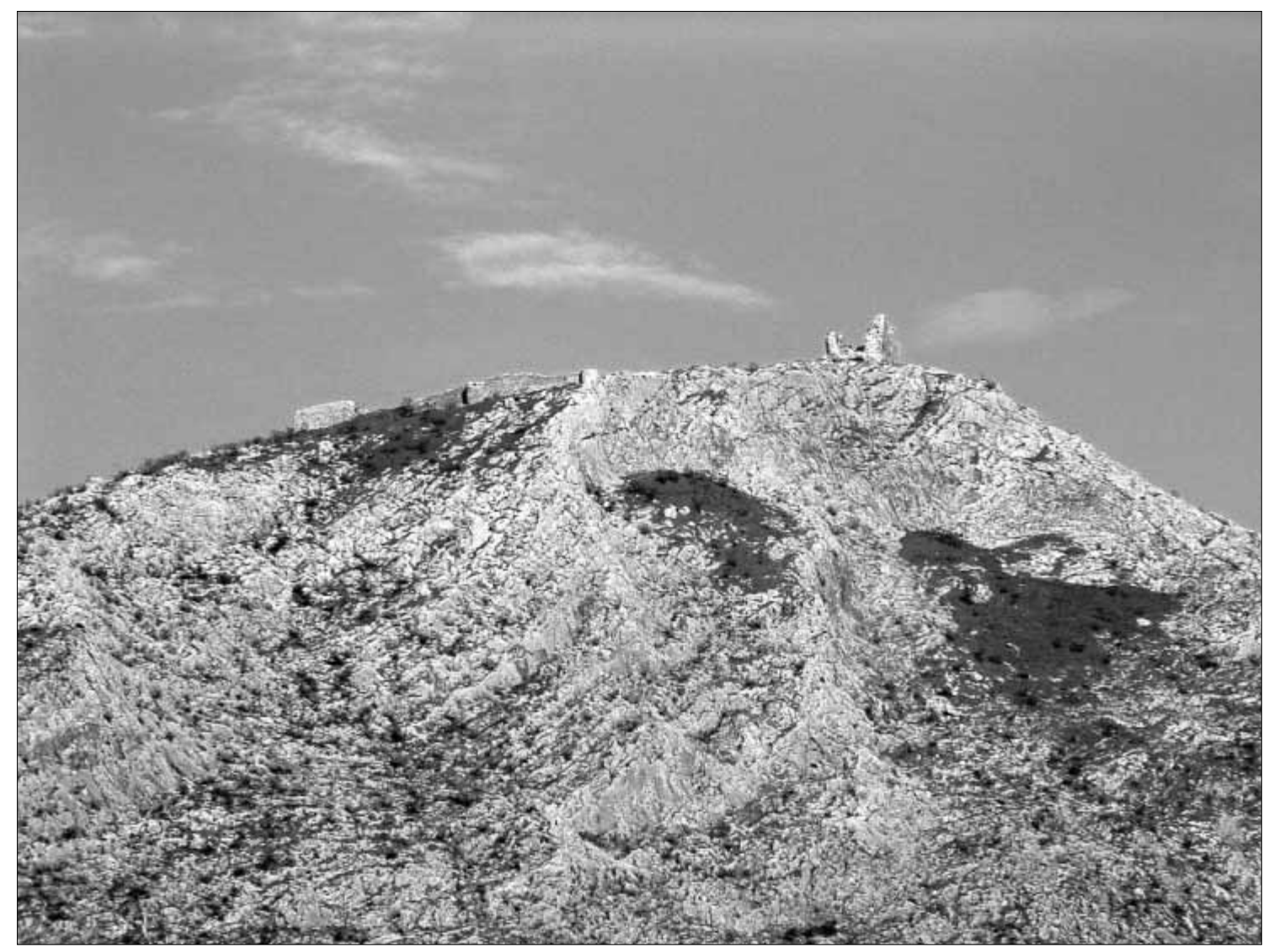

Lam. 33. Fortificación de la Peña de Martos

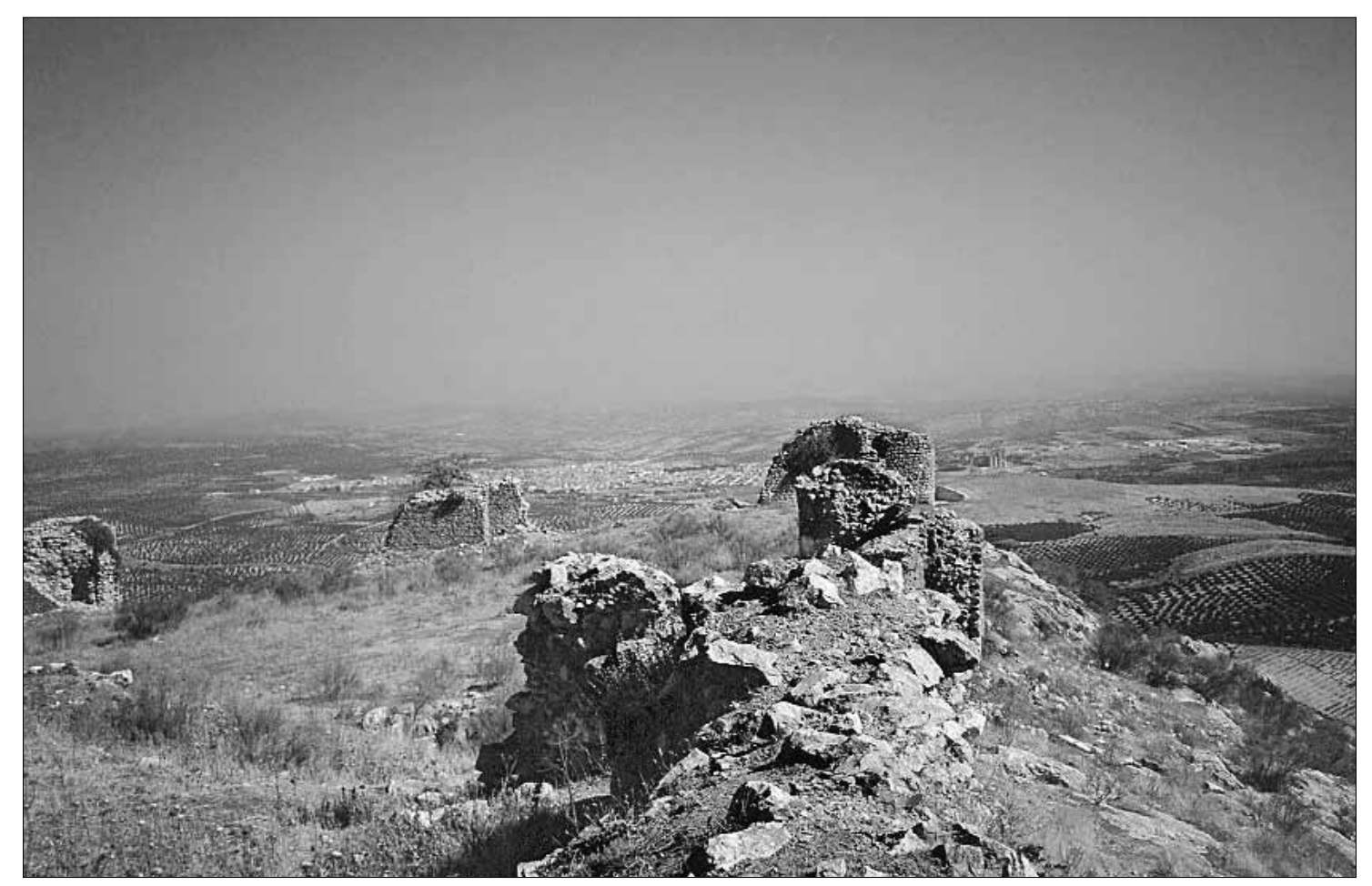

Lam. 34. Murallas del Primer Recinto de la Peña de Martos 


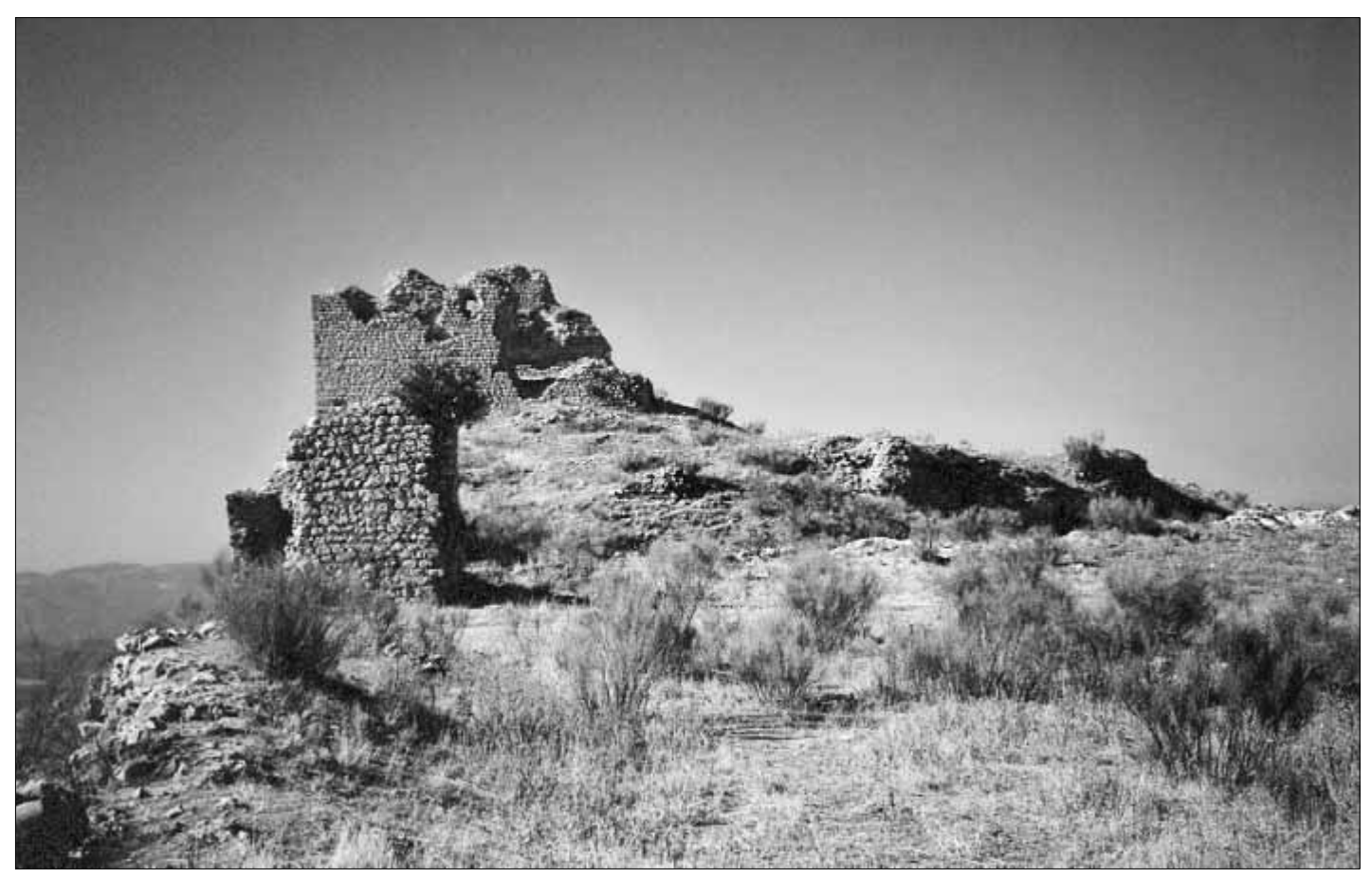

Lam. 35. Alcázar del castillo de la Peña de Martos

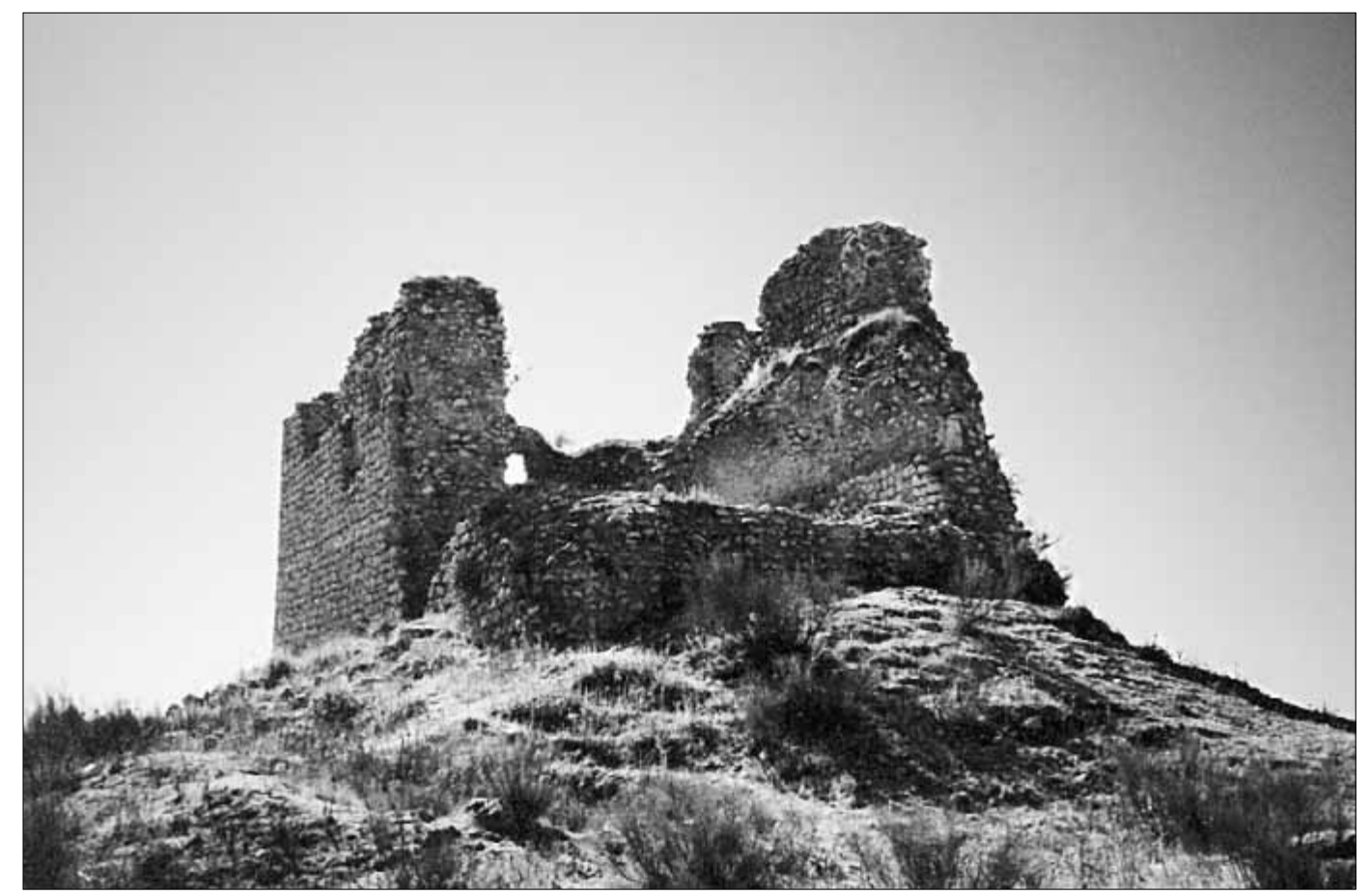

Lam. 36. Torre del Homenaje de la Peña de Martos 


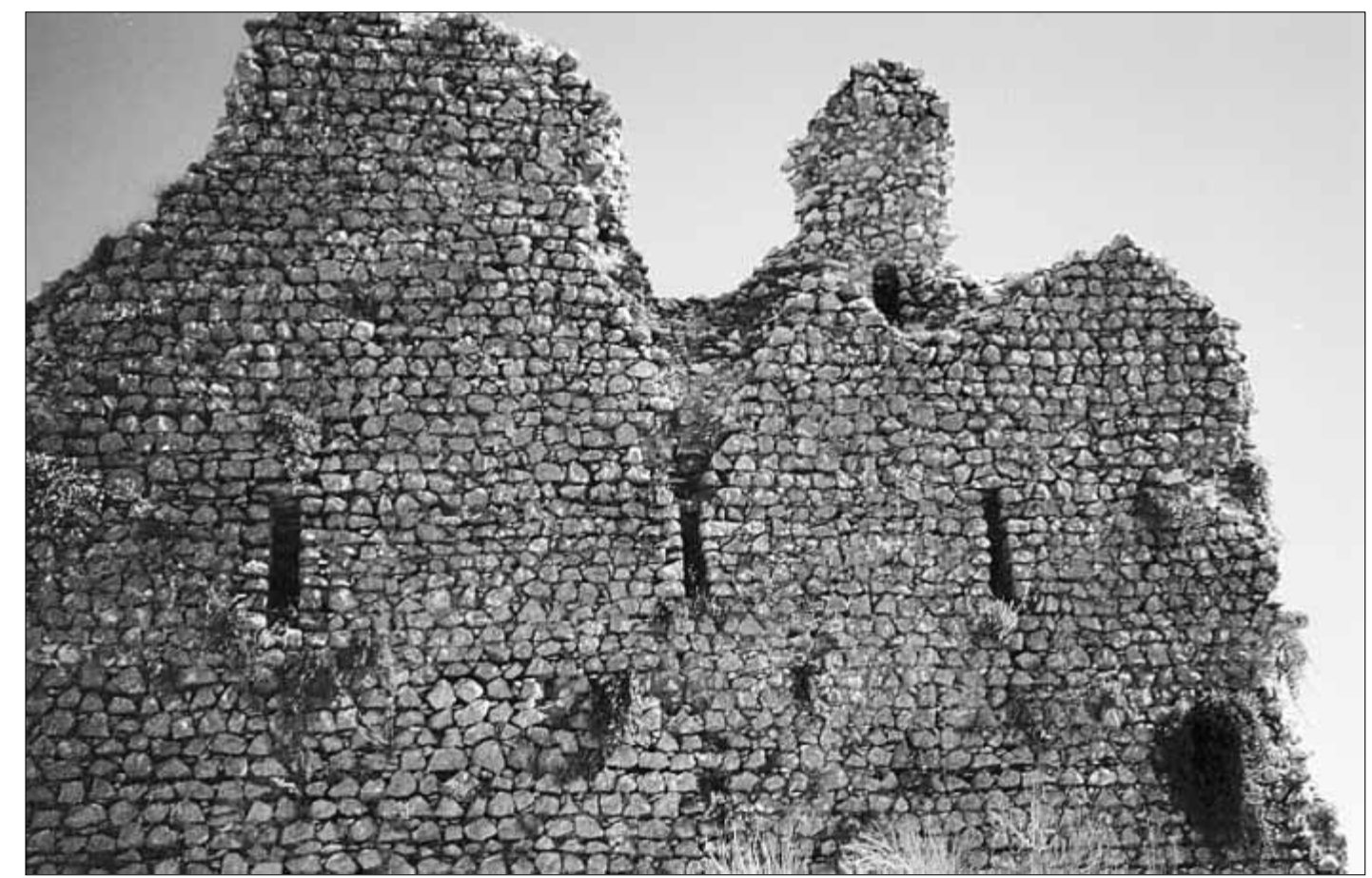

Lam. 37. Torre del Homenaje de la Peña de Martos

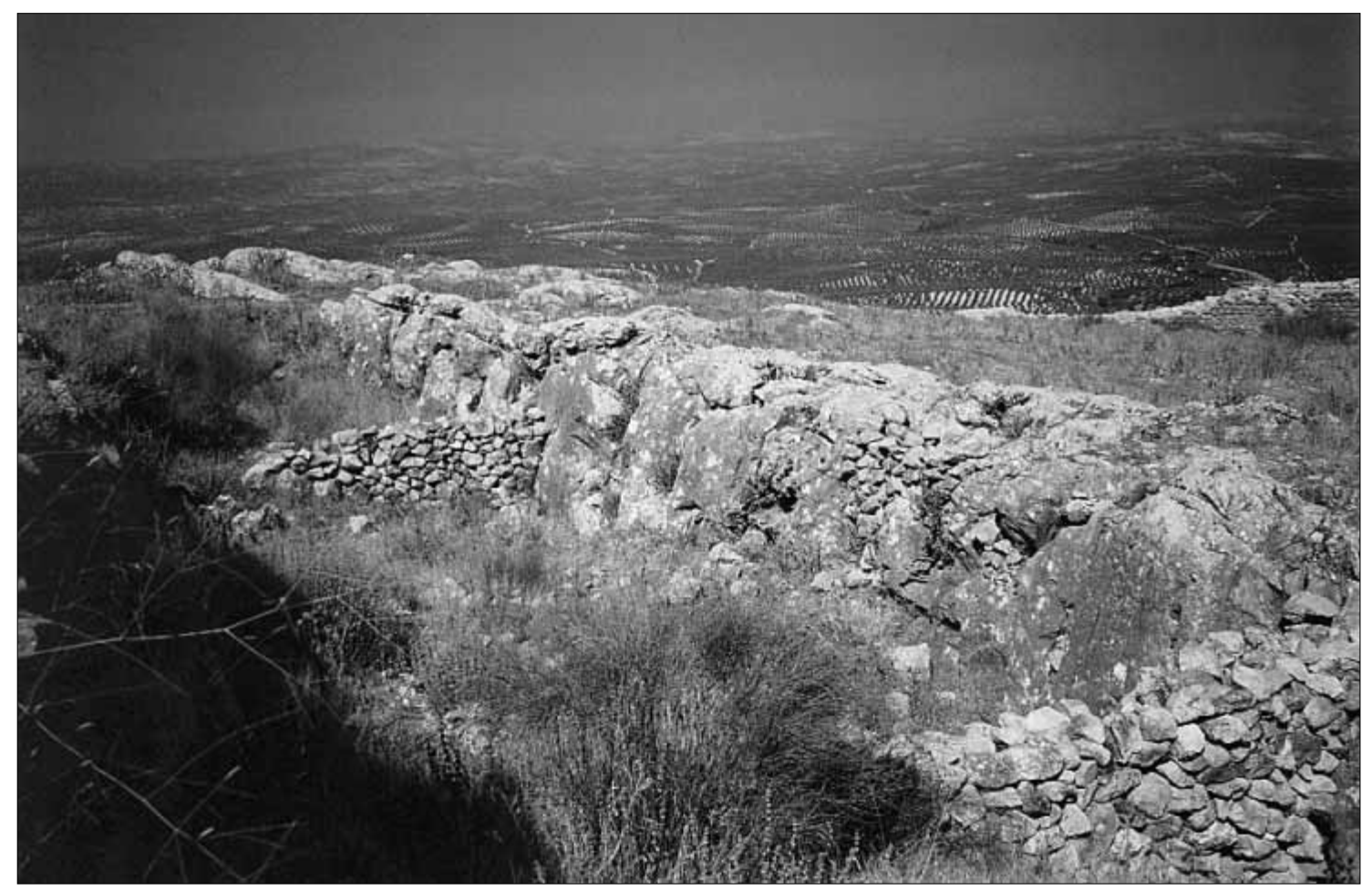

Lam. 38. Foso de la Peña de Martos 


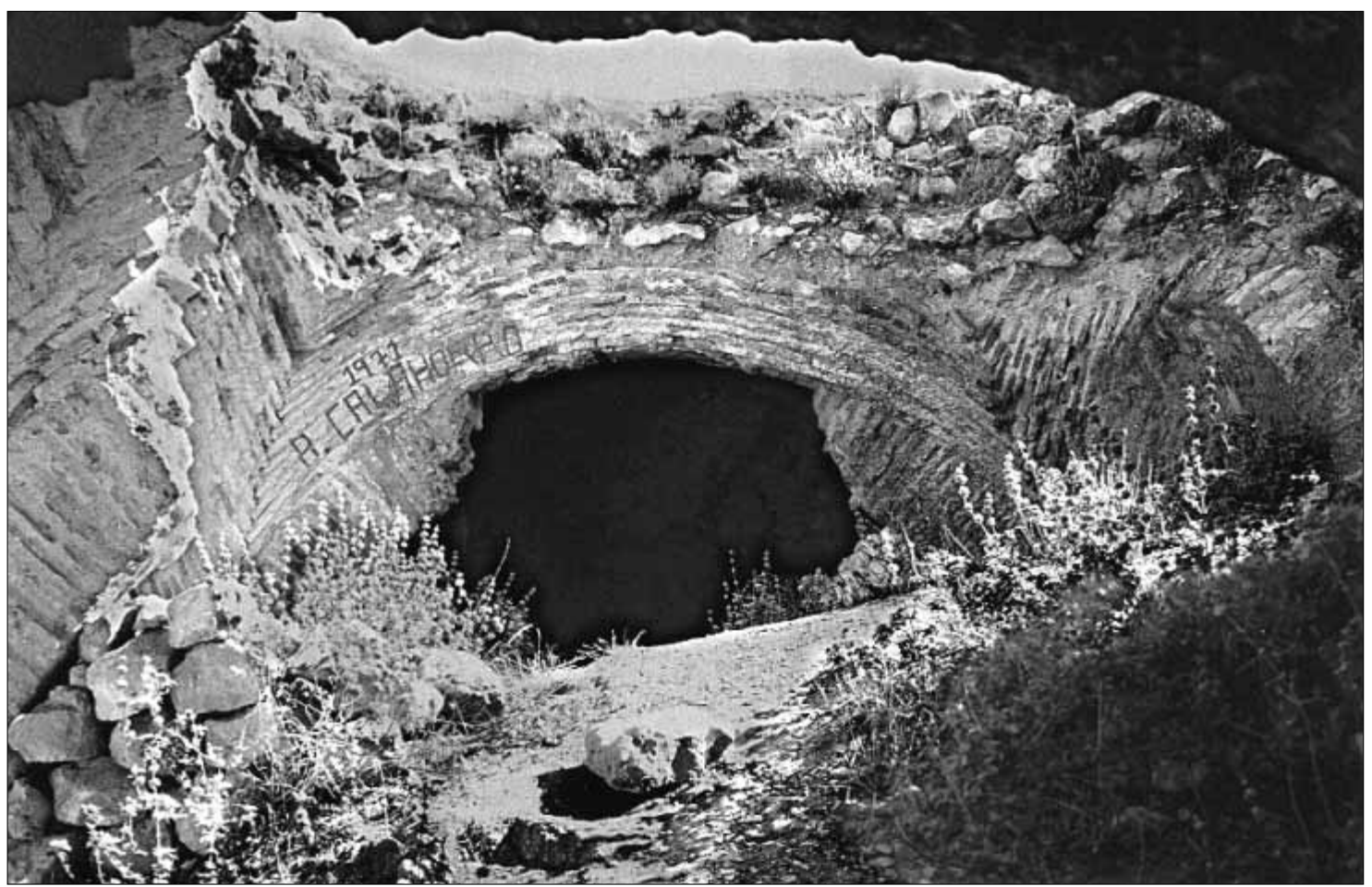

Lam. 39. Aljibe del Castillo

de la Peña de Martos

Lam. 40. Alcázar de Lopera

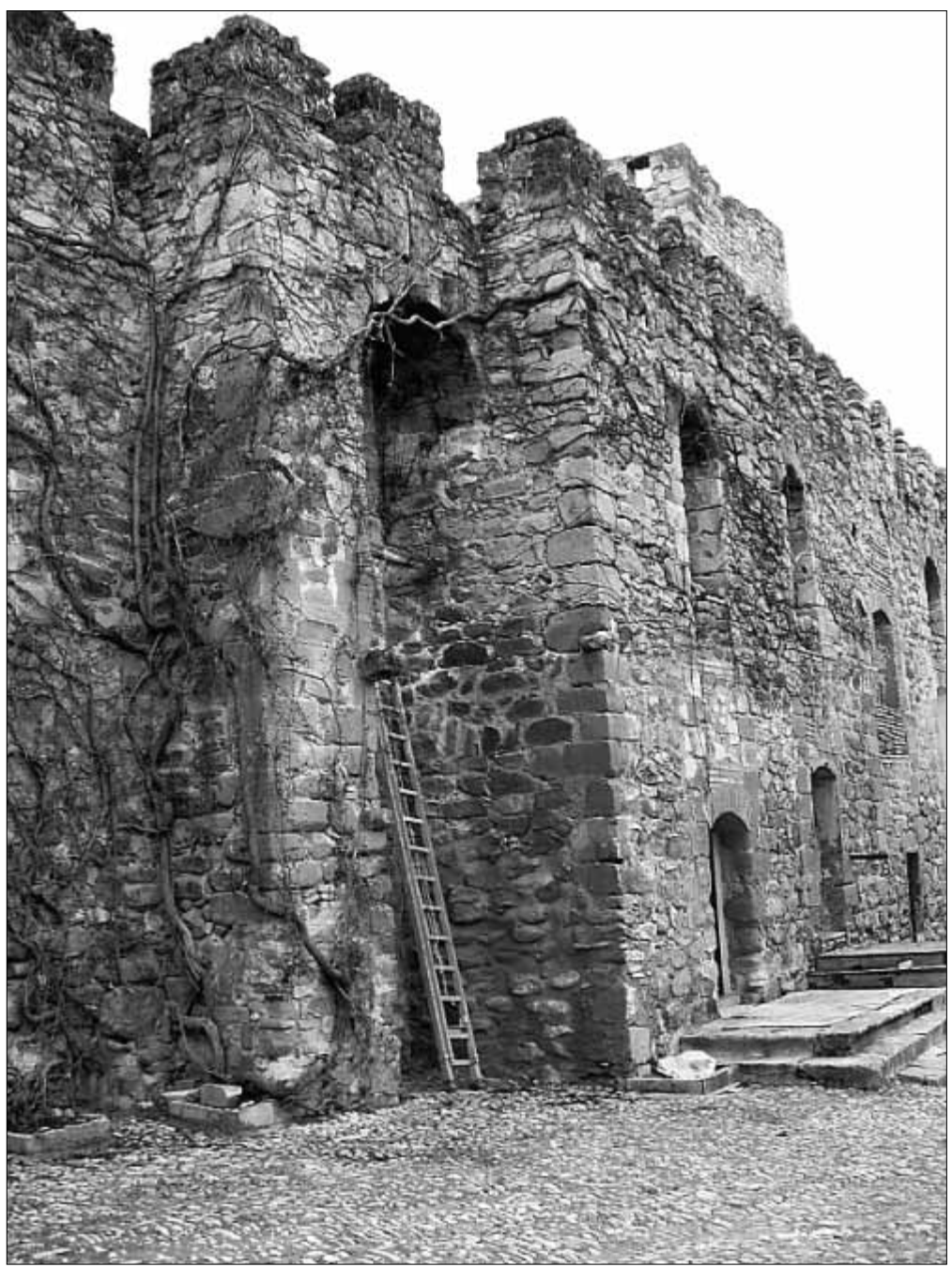




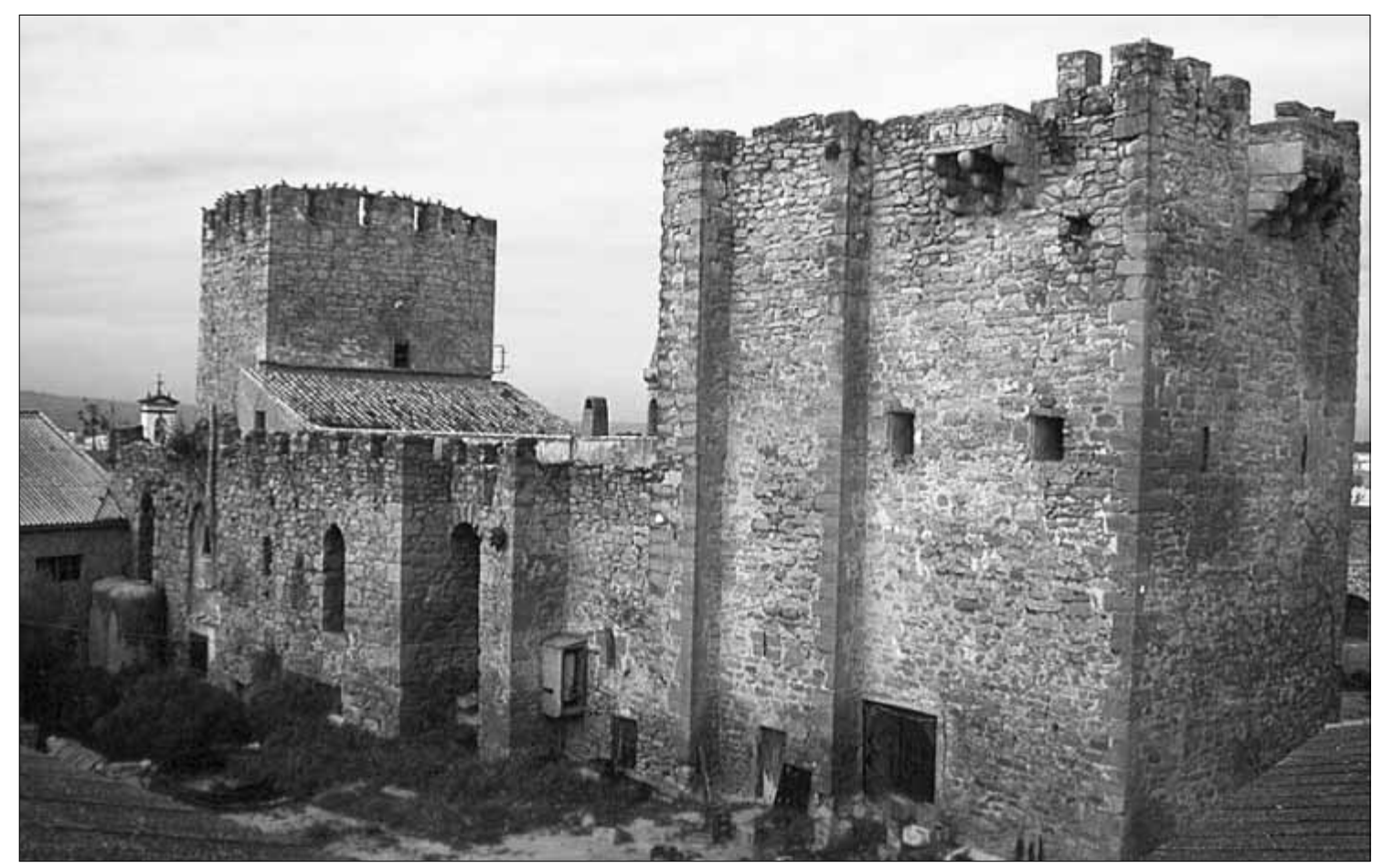

Lam. 4I. Alcázar de Lopera

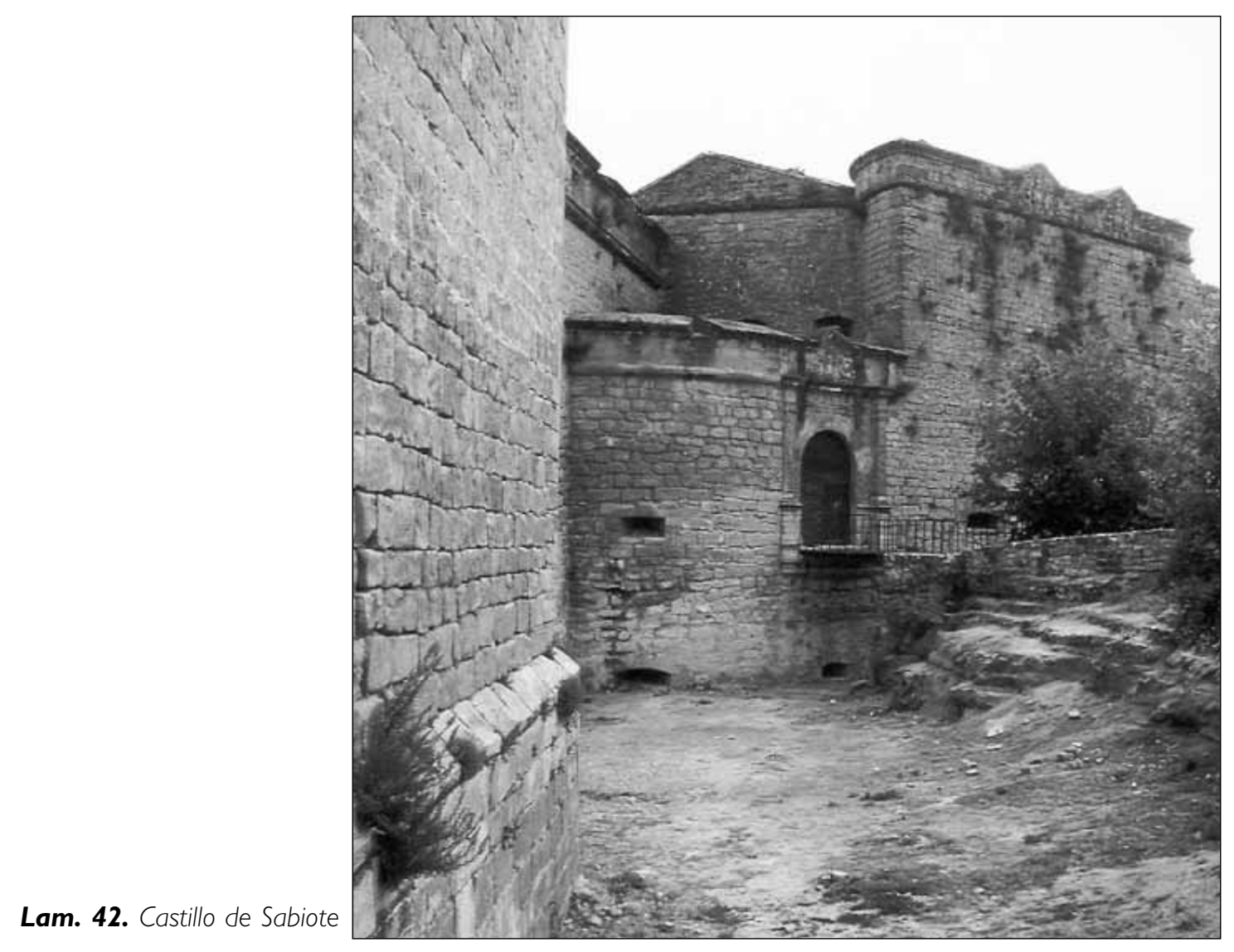




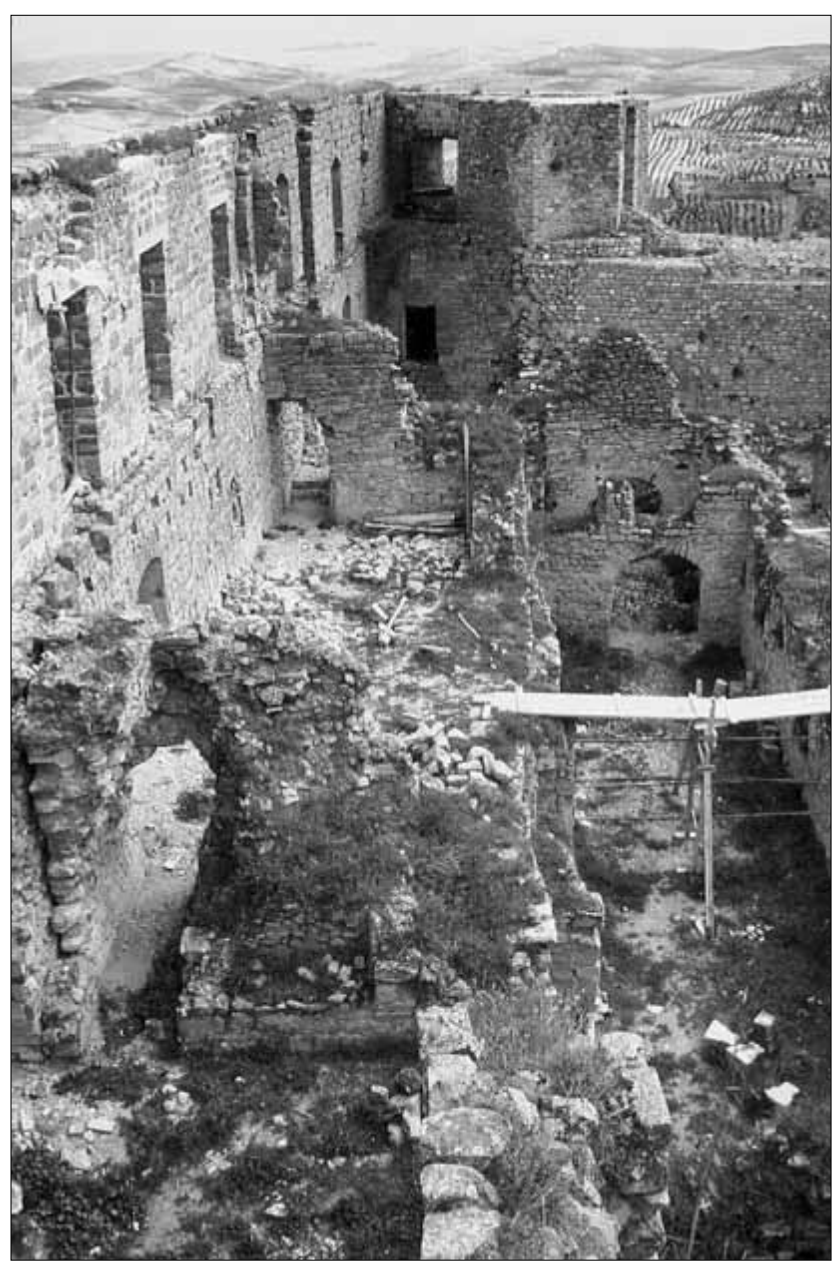

Lam. 43. Foso y Patio de

Armas del Castillo de Sabiote

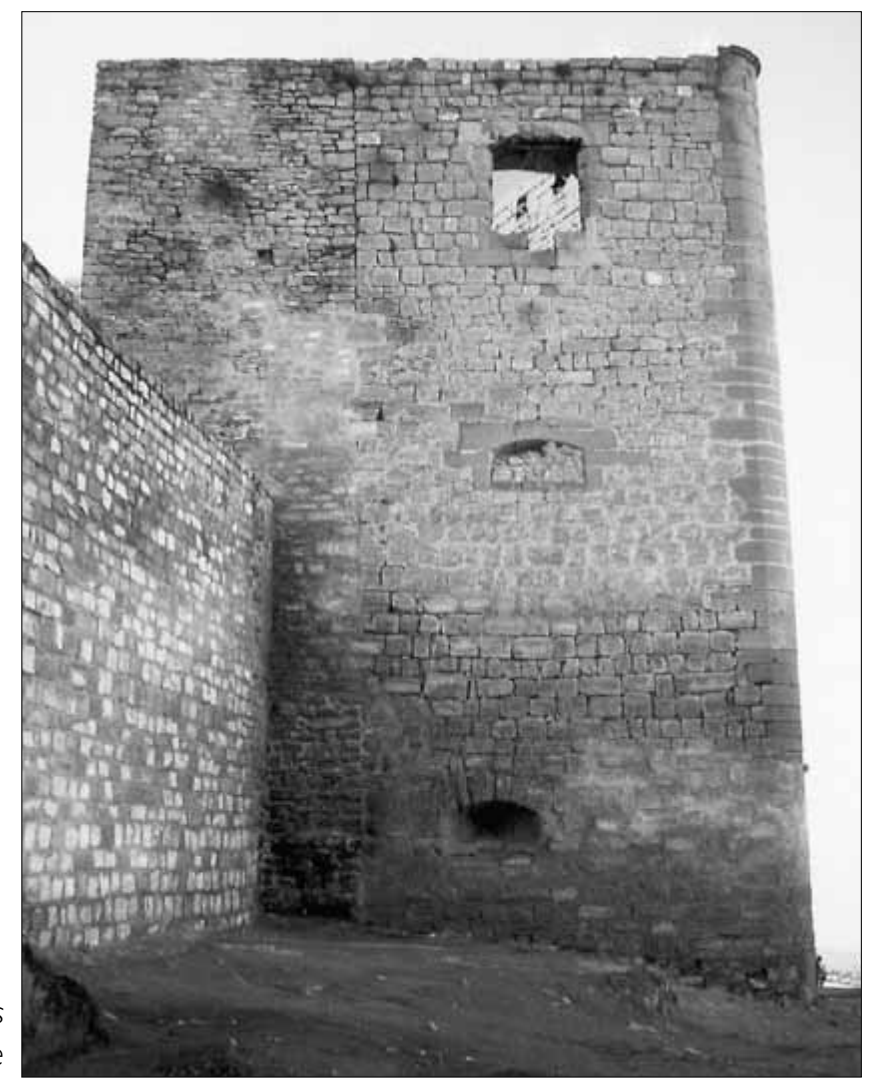

